DIW BERLIN

Discussion Papers

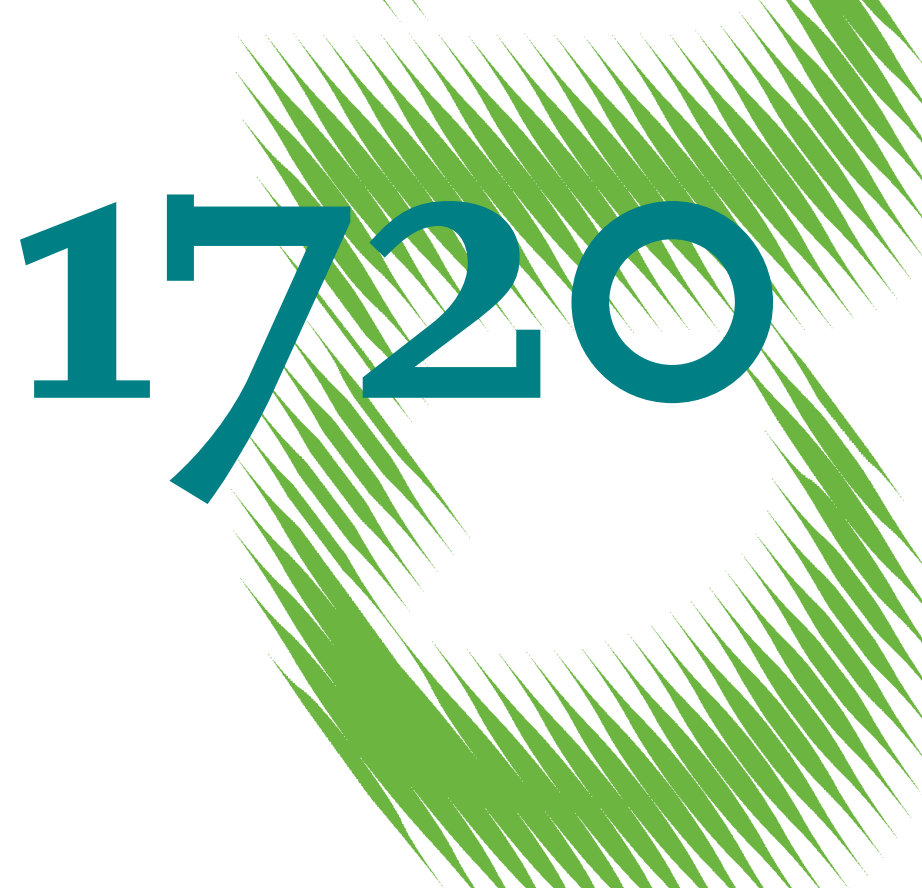

Financial Literacy and Intra-household Decision Making

Evidence from Rwanda 
Opinions expressed in this paper are those of the author(s) and do not necessarily reflect views of the institute.

IMPRESSUM

(C) DIW Berlin, 2018

DIW Berlin

German Institute for Economic Research

Mohrenstr. 58

10117 Berlin

Tel. +49 (30) $89789-0$

Fax +49 (30) $89789-200$

http://www.diw.de

ISSN electronic edition 1619-4535

Papers can be downloaded free of charge from the DIW Berlin website:

http://www.diw.de/discussionpapers

Discussion Papers of DIW Berlin are indexed in RePEc and SSRN:

http://ideas.repec.org/s/diw/diwwpp.html

http://www.ssrn.com/link/DIW-Berlin-German-Inst-Econ-Res.html 


\title{
Financial literacy and Intra-household Decision Making: Evidence from Rwanda*
}

\author{
Antonia Grohmann ${ }^{\dagger}$ and Annekathrin Schoofs ${ }^{\ddagger}$ \\ February, 2018
}

\begin{abstract}
Despite considerable policy efforts, women continue to be underrepresented in positions of power and decision making. As an important aspect of women empowerment, we examine women's participation in intrahousehold financial decision making and how this is affected by financial literacy. Using both OLS and IV regression analysis, we show that women with higher financial literacy are more involved in household financial decisions. In line with the literature, we further find that women are less financially literate than men. Results from decomposition analysis show that education and personality traits (openness, happiness, and depression) drive this financial literacy gender gap.
\end{abstract}

Keywords: financial literacy, women empowerment, intra-household decision making

JEL Classification: D 14 (personal finance), J 16 (economics of gender), G 02 (behavioural finance: underlying principles)

\footnotetext{
*The authors gratefully acknowledge the support of a special grant (Sondertatbestand) from the German Federal Ministry for Economic Affairs and Energy and the Ministry of Innovation, Science, and Research of the State of North Rhine-Westphalia. The data underlying this research was collected in cooperation with Genesis Analytics and ikapadata for an impact evaluation commissioned by CARE Canada and MasterCard Foundation. The authors are grateful to Noel Verrinder for valuable input to the study design and fruitful cooperation in implementing the survey, and to participants of a number of conferences, as well as Olaf Huebler, Lukas Menkhoff, Sebastian Schneider and Jörg Peters for useful comments.

${ }^{\dagger}$ Antonia Grohmann, International Economics, DIW Berlin, Mohrenstraße 58, 10117 Berlin, Germany, agrohmann@diw.de.

${ }^{\ddagger}$ Corresponding author: Annekathrin Schoofs, RWI (Berlin Office), Invalidenstraße 112, 10115 Berlin, Germany, annekathrin.schoofs@rwi-essen.de.
} 



\section{Introduction}

Gender equality in decision making processes has been a global policy objective for over 20 years (Beijing Declaration, 1995). Yet women continue to be underrepresented in positions of power and decision making. Only recently, the United Nations (UN) again put women's participation in political, economic and public decision making as an explicit policy goal on top on the "2030 Agenda for Sustainable Development" (UN, 2015). Strengthening women empowerment is not only a desirable goal in itself but is also believed to have positive effects on many other goals of this universal agenda (Duflo, 2012). Indeed, women as household decision makers can have important protective implication on child mortality (Moursund and Kravdal, 2003; Thomas, 1990), household nutrition, health and education (Thomas, 1993; Duflo, 2003; DFID, 2010).

The process of enhancing women's capacity to make choices is an integral part of women empowerment (Alsop et al., 2005). In an early concept, Kabeer (1999) divides the ability to make choices into three moments in time. She frames the first moment as pre-condition or resource, the second moment as action or agency, and the third one as achievement; whereby agency tends to be operationalized as decision making. Resources comprise material resources, such as income, asset and land ownership, but have also been defined more broadly as human capital (see Doss, 2013; Fiala and He, 2017, for reviews). ${ }^{1}$

In this paper, we examine the effect of a specific type of human capital, that is financial literacy, on a specific type of agency, namely financial decision making within the household. Financial literacy means understanding of financial concepts, such as interest rate, risk diversification and inflation. Following the framework developed by Kabeer (1999), financial literacy should act as a resource of empowerment by increasing women's ability and self-confidence to make financial decisions and ultimately enhance their involvement in intra-household decision making. We define decision making on the household level as involvement in financial decisions regarding income, credit, investment and expenditures.

We first test, using both ordinary least squares (OLS) and instrumental variable (IV) regression analysis, whether women with higher financial literacy are more involved in household financial decisions. In a second step, we look at the difference in financial literacy between men and women. We show that in line with the literature (Xu and Zia, 2012; Bucher-Koenen et al., 2017), women have lower financial literacy

\footnotetext{
${ }^{1}$ In his economic theory, Sen et al. (1999) brings resources and agency together as capabilities.
} 
than men. Motivated by these two findings, we perform a detailed decomposition analysis to study the sources of the financial literacy gender gap.

Our analyses are based on household data collected from savings group members in the Southern Province of rural Rwanda. Unlike previous household surveys, the sample does not only include the household head and hence the potential financial decision maker, but instead is representative for all savings group members in southern Rwanda.

First, we only look at women in our sample and find that women with higher financial literacy are more involved in intra-household decision making. OLS results show that women with higher financial literacy are more likely to report that they are involved in all types of financial decisions and most expenditure decisions. Moreover, women with higher financial literacy are less likely to claim that their husbands make financial household decisions alone. The cross sectional design of this study prevents us from making causal statements based on linear regressions. Simultaneous causality may be a problem in such regressions. Although we hypothesize a positive change in women's involvement in household financial decisions due to increased financial literacy, causality may occur in both directions leading to a biased coefficient. We, therefore, perform IV regressions using the average group level of financial literacy excluding the individual that is examined as an instrument. This approach avoids an internal correlation and yields an instrument that is highly correlated with the financial literacy level of the individual itself as savings groups are likely to learn from each other about financial matters. At the same time, we argue that the level of financial literacy of the rest of the group has no other effect on household financial decisions, apart from financial literacy. We provide several robustness tests to validate our instrument and to argue that intra-household decision making is a private process determined by the members of that household, and not correlated with the average group financial literacy level. Overall, the IV specification confirms the statistically significant positive effect of financial literacy on financial decision making within the household.

Second, we perform linear and non-linear decomposition analyses to investigate the sources of the financial literacy gender gap. These analyses break down the gender gap in financial literacy into differences based on observed characteristics ("the endowment effect") and differences in returns on these characteristics ("the coefficient effect"). Unlike previous studies that examine gender differences in financial literacy, we have information on deeply rooted personality traits. The results show that $47 \%$ of the gap stems from gender differences in endowments, particularly women's lower 
educational attainment (18\%), lower openness for new ideas (13\%), lower happiness $(5 \%)$, and greater symptoms of depression (3\%). $57 \%$ of the gender gap stems from gender differences in returns on characteristics. This indicates that women may face different environments that we believe to be shaped by cultural and societal values that influence how their endowments are translated into financial literacy. Our results hence inform policymakers who aim to reduce the gender gap in financial literacy by highlighting the importance of personal characteristics and the cultural and societal context the person lives in. This in turn may provide an indication of how women's involvement in intra-household decision making can be increased.

This paper is linked to two different strands of literature: (i) the literature on measurement and determinants of intra-household decision making, and (ii) the literature on the effect of financial literacy on financial decision making.

(i) Similar to previous empirical studies, our outcome measure is related to intrahousehold decision making processes, rather than themselves being a final economic outcome. Allendorf (2007), for instance, uses the 2001 Demographic and Health Survey (DHS) to study the relationship between land ownership and intra-household decision making in Nepal. Outcome measures are binary variables indicating whether the respondent has the final say on her own health care, household expenditures and visits. She finds that female landowners are more likely to be involved in these decisions than women who do not own land and that in turn their children are more likely to be better nourished. Mabsout and Van Staveren (2010) use the same questions from the 2005 Ethiopian DHS to show the relevance of ethnicity in intra-household decisions. Connelly et al. (2010) analyze the effect of migration and return home for Chinese women on their position in the household. Women's migration status seems to be largely unrelated to women's involvement in intra-household decision making, except of her decision to migrate and gift giving.

Other determinants of intra-household decision making have empirically and theoretically been examined, especially with regard to income. McElroy and Horney (1981) argue in an early household model that women's earned income is clearly related to women's decision making power. A set of later studies support this theory; showing that an increase in women's income positively affects women's involvement in intra-household decisions regarding health, education and household expenses, her own well being and contraceptive use (Thomas, 1990, 1993; Duflo, 2003; Anderson and Eswaran, 2009; Bobonis, 2009; De Brauw et al., 2014). The majority of estimations that use income rely on either randomized controlled trials (RCT) (e.g. cash transfer programmes) or IV analysis. Doss (2001) and Duflo and Udry (2004) for 
instance use rainfall shocks to instrument for women's agricultural income and find expenditure shifts towards education and food.

More evidence exists on the effect of access to financial services and intra-household decision making. Using an RCT, Ashraf et al. (2010) find that households are more likely to buy female-oriented durables when they get access to a commitment savings product. This implies women's increased control over decisions at home. Likewise, Hashemi et al. (1996) provide evidence that membership of the Grameen Bank or the Bangladesh Rural Advancement Committee increases the involvement in household decisions and in making purchases. Although these studies constitute an important background of our work, basic questions about the channels through which intrahousehold decisions are affected by access to financial services remain unclear; in particular, whether financial literacy is one mechanism that underlies these results.

(ii) Lusardi and Mitchell (2014) review the literature on financial literacy and financial decisions. So far, the focus has been on financial outcomes rather than on decision making processes. IV analyses are used to show that financial literacy improves retirement planning (Lusardi and Mitchell, 2007), wealth accumulation (van Rooij et al., 2012), stock market participation (van Rooij et al., 2011) and reduces the amount of debt held (Lusardi and Tufano, 2015; Gathergood, 2012). For developing countries, the literature is less extensive and the majority experimentally evaluate financial literacy programmes (see Kaiser and Menkhoff, 2017, for a meta-analysis). In Indonesia and India, Cole et al. (2011) find only modest effects on account ownership for the poorest segment of the treated populations. Doi et al. (2014) and Sayinzoga et al. (2015) find significant impacts of financial literacy trainings on savings in the Philippines and Rwanda, respectively.

The literature commonly concludes that financial literacy levels are low among the population and that women have lower financial literacy than men (Xu and Zia, 2012; Bucher-Koenen et al., 2017). Even the most educated women show deficiencies in their financial knowledge (Mahdavi and Horton, 2014). To our knowledge, there are only three exceptions, in Russia (Klapper and Panos, 2011), Thailand (Grohmann et al., 2016), and some regions of India (Filipiak and Walle, 2015). So far, only very little evidence exists on the reasons behind this gender gap. Grohmann et al. (2016) argue that the gender gap is caused by culture and that financial literacy is similar by gender in Thailand because Thai women are traditionally in charge of financial matters. Likewise, Filipiak and Walle (2015) find that women in matrilineal societies in India have better financial literacy than women living in patrilineal societies. Hsu (2016) attributes women's lower financial literacy to specialization of tasks within the house- 
hold.

To our knowledge, this is the first quantitative study that aims to understand the link between financial literacy and intra-household decision making, in particular women's involvement in these processes. We also extent the scope of the financial literacy and gender gap literature by looking at deeply rooted personality traits in a detailed decomposition analysis.

Following this introduction, the remainder of the paper is organized as follows: Section 2 describes the data. Section 3 looks at women's involvement in household decisions. In Section 4, we perform a decomposition analysis. Section 5 provides robustness and Section 6 concludes.

\section{Data}

\subsection{Savings groups}

Our analysis relies on primary household data of savings groups in the Southern Province of Rwanda, a rural area where the majority of people save in informal groups such as tontines or Village Savings and Loan Groups (VSLGs). ${ }^{2}$ A typical VSLG in Rwanda is gender-mixed and consists of 15 to 30 people. Members meet once a week to contribute to or borrow from a shared fund. Eight to twelve months after the savings circle has started, each member will receive her share-out of the fund and her accumulated savings.

We assume that this regular meeting and contribution structure may increase understanding of financial concepts. It also leads to a similarly high interest in money management that likely goes beyond the financial literacy of other rural residents. The decomposition analysis benefits from this as unobservable factors related to financial interest can to some extent be neglected. Given that members voluntarily select themselves into groups, it is possible that the composition of groups is related to wealth or education. A comparison of our sample to the Rwandan Housing and Population Census 2012 (NISR, 2012) shows that the sample is comparatively less educated and poorer than the overall Rwandan population. This is, however, not systematic between men and women, which makes the sample suitable to study gender differences.

\footnotetext{
${ }^{2}$ See Karlan et al. (2017) for a detailed description of the VSLG model.
} 


\subsection{Sampling}

Sampling was done in two random stages. First, we stratified the sample by district and drew a total of 300 VSLGs from a complete list of all active VSLGs in southern Rwanda. Second, we randomly selected five individuals from each VSLG. This was done by first compiling a list of all active members of the visited VSLG. Using smart mobile devices, a random number generator then randomly selected five names from this list. Our sample is, hence, representative for VSLG members in Rwanda's Southern Province. We designed the questionnaire specifically to answer questions regarding financial issues of the household. It contains questions on the household's socio-demographic variables, household composition, intra-household decision making, financial services used and financial literacy. Each interview took about 45 minutes.

The final sample collected in 2015 covers 283 of the 300 sampled VSLGs and about 1400 respondents. The target population is older than 18 years. Respondents also qualify as poor according to Rwanda's poverty levels ${ }^{3}$ and have limited access to formal financial services provider. 17 VSLGs either no longer existed or could not be reached. No VSLG refused to participate in the survey.

\section{Descriptive statistics and variables}

\subsection{Socio-demographics}

Summary statistics are presented in Table 1 separated by gender. Respondents are on average forty years old, married and poorly educated. Only 57\% of women and $72 \%$ of men can spell a simple word in the local language correctly. Women are also more likely to be widowed. Looking at measures for personality such as happiness and the depression index ${ }^{4}$, women's indices are below that of men. The majority of respondents report farming as their main occupation, which is undertaken independently and in employment for others. The average household size is about 5 and thus larger than reported in many other countries. We further learn that the highest proportion of

\footnotetext{
${ }^{3}$ In Rwanda, poor people are selected into the first or second "Ubudehe category".

${ }^{4}$ We use the widely known "Center for Epidemiologic Studies Depression Scale Revised" (CESD-R). It is standard battery of 20 questions that measure depression and depressive disorders in nine different groups: sadness, loss of interest, appetite, sleep, thinking / concentration, guilt, tired, movement, suicidal ideation (Radloff, 1977; Eaton et al., 2004).
} 
female savings groups members tend to belong to the lowest income quartile. ${ }^{5}$ On the contrary, the highest proportion of their male counterparts belong to the upper income quartile. We also construct an asset index that is the first principal component of the respondents reported assets. This asset index indicates that women participate in VSLG out of poorer households than men. Moreover, mobile phone ownership is less likely in households of female than male savings groups members.

- set Table 1 about here -

\subsection{Intra-household decision making}

The first part of this paper focuses on financial decision making as outcomes of interest. Outcome variables are defined by questions on who within the household decides over income, credit, investment, and expenditure decisions. The latter is further divided into energy and food expenses of the household, the women's own health and clothing expenses, and the children's health and clothing expenses. These indicators are similar to those included in the DHS and have previously been used to study intra-household decision making by Allendorf (2007) and Connelly et al. (2010).

Table 2 provides descriptive statistics. The majority of both sexes indicate to jointly decide on financial matters. Further, women are more likely to report that they either make the decision themselves or that their husbands make the decision alone, whereas men are more likely to report that both partners make the decision together. The patterns we observe are consistent for all types of financial decisions. One reason may be that men are more likely to decide if there is a couple living in the household. However, as shown above, women are more likely to be widowed. That could imply that they live alone and hence have to take decisions by themselves.

- set Table 2 about here -

\subsection{Financial literacy gender gap}

We measure financial literay using an adjusted version of the Lusardi and Mitchell (2011) questions and developed further by Cole et al. (2011). This approach focuses on numeracy skills for calculating financial trade-offs. Questions that were asked are the following:

\footnotetext{
${ }^{5}$ We use expenditures to proxy for income. All expenditure categories were aggregated on a yearly base and further divided into fourths.
} 
- Suppose you borrow RWF 10,000 from a moneylender at an interest rate of $2 \%$ per month, with no repayment for 3 months. After 3 months, do you owe less than RWF 10,200, exactly RWF 10,200, or more than RWF 10,200?

- If you have RWF 10,000 in a savings account earning $1 \%$ interest per annum, and prices for goods and services rise $2 \%$ over a 1-year period, can you buy more than, less than, or the same amount of goods in 1 year as you could today, with the money in the account?

- Is it riskier to plant multiple crops or one crop?

- Suppose you need to borrow RWF 50,000. Two people offer you a loan. One loan requires you to pay back RWF 60,000 in 1 month. The second loan requires you to pay back in 1 month RWF 50,000 plus $15 \%$ interest. Which loan represents a better deal for you?

All questions were multiple choice; two questions with two possible answers and two questions with three possible answers. Respondents also had the option to answer "I don't know" or to refuse to answer. For each question the respondent provides a correct answer for, she receives one point. That means that the aggregated financial literacy index ranges from zero to four.

In comparison to studies in countries with a similar level of development, respondents in our Rwandan sample are slightly more financially literate, for example more literate than the Indian sample used in Cole et al. (2011). The proportion of correct answers is highest for the question on risk-diversification. Since $92 \%$ of respondents are working in the agricultural sector, this might be obvious as the question is framed in a manner requiring agricultural knowledge. In contrast, the knowledge related to basic numeracy skills is low.

Figure 1 shows the share of correct answers broken down by gender. On average, women are less likely than men to provide correct answers. Only $45 \%$ of female respondents and $61 \%$ of male respondents correctly answered the borrowing decision. $57 \%$ of men showed basic understanding of interest and inflation. In contrast, only $45 \%$ of women correctly dealt with these economic concepts (see Table 3 ). While $34 \%$ of men correctly answered all four questions, only $22 \%$ of women did so. The financial literacy level is significantly lower for women than for men irrespective of how financial literacy is measured (see Table 4).

- set Figure 1 about here - 
Furthermore, women are more likely to indicate that they do not know the correct answer. As many as $26 \%$ of women indicated that they do not know the answer to the first compound interest question, whereas the proportion of men is much lower (15\%) (see Table 3). 35\% of women gave at least one "don't know" response to one of four financial literacy questions, the proportion of men doing so is about 19\% (see Table 4). We hereby confirm results found in other studies on financial literacy and gender, where women perform worse than men and are also more likely to say that they do not know the answer (Bucher-Koenen et al., 2017).

- set Table 3 about here -

- set Table 4 about here -

\section{Financial literacy and decision making}

\subsection{OLS analysis}

We now study covariates of intra-household decision making with a focus on financial literacy. Using multivariate regression analyses, we look at two outcome measures for each question. The first outcome measure is one if women either decide on their own or jointly with their husbands. A zero is assigned if the husband or someone else makes the decision. The second outcome measure takes the value of one if women report that their husbands make the decision alone, and zero otherwise. In the following we refer to these two outcomes as "women's involvement" and "purely male". The decisions included are income, credit, investment and expenditure decisions. Moreover, we aggregate two overall indices as additional outcome variables for women's involvement. The first one counts the number of financial decisions (income, credit, investment) a women is involved in. The second one counts all expenditure decisions a women is involved in. The results are shown in Tables 5, 6 and 7 .

The main explanatory variable of interest is financial literacy, which we include as an index between zero and four (see Section 3.3). We control for individual characteristics such as age, being literate, and marital status as well as household level variables like household size, number of children, economic status (captured by an index for household assets) and expenditure quartiles. This analysis is restricted to women. Examining the first outcome indicator, "women's involvement", we deliberately look at all types of marital status because even daughters, widows or unmarried women may face challenges to control decisions at home. Nevertheless, we repeat the analysis 
looking at married women only (see Tables B.3 and B.4 in the Appendix).

Our results show that financial literacy is positively correlated with women's involvement in intra-household decision making. The effect is positive and statistically significant for all decisions, except for the ones related to expenditures on children. When looking at the two indices for women's involvement, the results also show that women with higher financial literacy are more involved in more household decisions. Furthermore, more financially literate women are less likely to report "purely male" decision making. The financial literacy index is negatively and significantly correlated with most questions, except income and expenditures on children. As for the control variables, age is positively correlated with women's involvement in household decisions. Interestingly, the household size is negatively correlated with "women's involvement", but the number of children are not or weakly correlated with women's involvement in intra-household decisions. In most cases, married women are also less likely to participate in household decision making.

- set Table 5 about here -
- set Table 6 about here -
- set Table 7 about here -

\subsection{IV analysis}

In line with the concept by Kabeer (1999), financial literacy can be thought of as a resource that affects decision making. The previous section supports this argument showing robust correlations between financial literacy and intra-household decision making. The cross sectional design of this study, however, poses potential endogeneity problems due to omitted variable bias or reverse causality. For example, unobservable personal attributes could drive financial literacy and decision making at the same time. Similarly, it is possible that reverse causality is at play and that decision makers use their greater agency to learn about financial matters. Of course, better financial literacy might then further enhance involvement in household decisions.

In order to address these concerns, we employ an IV approach. We collected a number of potential instruments such as whether parents taught budgeting, the distance to the nearest school, the proportion of people who report the nearest bank to be less than 30 minutes away, the proportion of people who report the nearest market to be less than 30 minutes away, the quality of the public transport. Yet, none of these 
potential instruments pass the standard tests for weak instruments. Instead, we use the VSLG's average financial literacy index excluding the individual that is examined as an instrument. This variable is highly correlated with the financial literacy of the individual as group members are likely to learn from each other. This is confirmed by the F-stat of the first stage regression shown in Table B.5 in the Appendix. Furthermore, the Wald-test for weak instrument theoretically justifies the validity of our instrument.

Following conventional intra-household decision making theory, we argue that each household member's contribution to the household determines decision making power at home (McElroy and Horney, 1981). Hence, we argue that there is no direct link between the average group financial literacy index and intra-household decision making because intra-household decision making is a private process determined by the members of that household. To strengthen this argument, Tables B.12, B.13 and B.14 in the Appendix show IV results with group fixed effects. These tables establish similar relationships between financial literacy and intra-household decision making, albeit not statistically significant. Another concern arises when some savings groups are on average more financially literate than others because they live in more progressive areas where women are also more involved in household decisions. Mapping the study groups indicates that the variation in VSLG average financial literacy is not systematic between rural and more urban areas (see Figure B.1). Table B.20 in the Appendix further shows no significant correlations between group financial literacy levels and distances to urban spots such as markets or health centers. We can, hence, rule out unobserved variables or selection into certain groups that are better financially educated as a result of regional settings. As a consequence, we believe that the only channel through which the instrument affects intra-household decision making is via the financial literacy of the individual.

The results are shown in Tables 8, 9 and 10. They reveal the same pattern as simple OLS regression analyses. Financial literacy has a significantly positive effect on women's involvement in intra-household decision making and a significantly negative effect on "purely male" decision making.

- set Table 8 about here -

- set Table 9 about here -

- set Table 10 about here - 


\section{Analyzing the financial literacy gender gap}

\subsection{Empirical strategy}

Previous sections show: (a) that there is a significant difference in financial literacy between men and women, and (b) that financial literacy is an important aspect for women's involvement in intra-household decision making. As a tangible consequence, this section investigates why men outperform women on financial literacy and so aims to inform policy makers on how to improve women's financial literacy. This will be done in two steps. First, we run a simple multivariate regression with the financial literacy index as dependent variable in order to explore the heterogeneity along potential covariates. Second, we use the multivariate decomposition technique popularized by Blinder (1973) and Oaxaca (1973) to study mean outcome differences in financial literacy between men and women. The decomposition tests two explanatory approaches: (i) one that explains differences based on observed characteristics ("the endowment effect"), and (ii) another that explains differences in returns on these characteristics ("the coefficient effect").

Differences in financial literacy may arise due to gender differences in endowments; for example, when women are less educated than men. What would be the average financial literacy of women if they would be just as educated as men? Would this counterfactual financial literacy level of women be improved? Or would women still face lower returns on education and thus score lower in financial literacy tests, most likely due to societal or environmental factors. Previous evidence shows that marital status, age, education, and income can only partially explain the difference in financial literacy between men and women (Fonseca et al., 2012; Bucher-Koenen et al., 2017). That is why we examine whether differences in financial literacy hold when we apply men's coefficients to women's endowments. ${ }^{6}$ These findings are important to inform policymakers who aim to reduce the gender gap in financial literacy by highlighting the relative contribution of personal characteristics (the endowment effect) and the cultural and societal context the person lives in (the coefficient effect).

A general formulation of the two-fold decomposition technique is provided by Yun (2004). He proposes to decompose differences not only in sample means but rather in first moments, and so to extend the linear Blinder-Oaxaca decomposition to non-linear models. Accordingly, the level of financial literacy, $Y$, can be explained by a given set

\footnotetext{
${ }^{6}$ Depending on the context of the research question, the coefficient effect has been interpreted in different ways. In the gender wage gap literature, for instance, this effect has often been used as a measure for discrimination (Blinder, 1973; Oaxaca, 1973).
} 
of observable characteristics, $X$, and coefficients, $\beta$ :

$$
Y=F(X \beta)
$$

where the mapping function, $F($.$) , can but not need to be linear as long as it is$ once differentiable (Yun, 2004). We estimate a linear probability model in the main specification and non-linear models as robustness checks. The difference in financial literacy, $Y$, at the first moment between men, $A$, and women, $B$, can be summarized in the following equation:

$$
\begin{aligned}
\bar{Y}_{A}-\bar{Y}_{B} & =\left[\overline{F\left(X_{A} \beta_{A}\right)}-\overline{F\left(X_{B} \beta_{B}\right)}\right] \\
& =[\underbrace{\overline{F\left(X_{A} \beta_{A}\right)}-\overline{F\left(X_{B} \beta_{A}\right)}}_{\text {endowment effect }}]+[\underbrace{\overline{F\left(X_{B} \beta_{A}\right)}-\overline{F\left(X_{B} \beta_{B}\right)}}_{\text {coefficient effect }}]
\end{aligned}
$$

The first part describes the overall endowment effect, whereby the latter indicates overall differences in coefficients. Estimating the relative contribution of each variable, $i$, to the total gender gap can yield a more detailed picture. Yun (2004) proposes to calculate weights to the endowments and coefficients effects as follows:

$$
\bar{Y}_{A}-\bar{Y}_{B}=\sum_{i=1}^{i=K} W_{\Delta X}^{i}\left[\overline{F\left(X_{A} \beta_{A}\right)}-\overline{F\left(X_{B} \beta_{A}\right)}\right]+\sum_{i=1}^{i=K} W_{\Delta \beta}^{i}\left[\overline{F\left(X_{B} \beta_{A}\right)}-\overline{F\left(X_{B} \beta_{B}\right)}\right]
$$

where

$$
\begin{aligned}
W_{\Delta X}^{i} & =\frac{\left(\bar{X}_{A}^{i}-\bar{X}_{B}^{i}\right) \beta_{A}^{i} f\left(\bar{X}_{A} \beta_{A}\right)}{\left(\bar{X}_{A}-\bar{X}_{B}\right) \beta_{A} f\left(\bar{X}_{A} \beta_{A}\right)}=\frac{\left(\bar{X}_{A}^{i}-\bar{X}_{B}^{i}\right) \beta_{A}^{i}}{\left(\bar{X}_{A}-\bar{X}_{B}\right) \beta_{A}} \\
W_{\Delta \beta}^{i} & =\frac{\bar{X}_{B}^{i}\left(\beta_{A}^{i}-\beta_{B}^{i}\right) f\left(\bar{X}_{B} \beta_{B}\right)}{\bar{X}_{B}\left(\beta_{A}-\beta_{B}\right) f\left(\bar{X}_{B} \beta_{B}\right)}=\frac{\bar{X}_{B}^{i}\left(\beta_{A}^{i}-\beta_{B}^{i}\right)}{\bar{X}_{B}\left(\beta_{A}-\beta_{B}\right)}
\end{aligned}
$$

Weights add up exactly to $1(100 \%)$ and can simply be calculated using the average values of characteristics and their coefficients (Yun, 2004). ${ }^{7}$

One caveat of detailed decomposition techniques is linked to categorical regressors. Usually, in a regression framework one of the categories is chosen to be the base category. Hence, it is set to zero and all comparisons will be made relative to that category. Oaxaca and Ransom (1999), however, show that the results of the detailed decomposition are not invariant to the choice of the (omitted) base category. A solution

\footnotetext{
${ }^{7}$ For non-linear models, however, results are sensitive to the order in which independent variables enter the decomposition. Yun (2004) proposes a convenient solution for the so-called "path dependence". He obtains weights from a first order Taylor expression to linearize the endowments and coefficients effects in equation (2) around $\bar{X}_{A} \beta_{A}$ and $\bar{X}_{B} \beta_{B}$.
} 
for this identification problem is to normalize the effects for a set of indicator variables representing one categorical regressor in the model (Yun, 2008). Our calculations are made accordingly.

\subsection{Regression results}

Table 11 shows results of the multivariate regression analysis. The outcome variable is the financial literacy index and the main variable of interest is the female dummy. For ease of interpretation, explanatory variables are collected into groups and separately introduced into the regression analysis.

Results are in line with Lusardi and Mitchell (2014). Women have significantly lower financial literacy than men. As for other control variables, age is humped shaped. Financial literacy first increases with age and then falls for the elderly. This effect turns statistically insignificant when adding household composition variables but its direction remains robust. The number of children in the household may thus be an alternative measure for being middle aged that absorbs the effect of age. For all specifications, our results also point to a strong and significantly positive relationship between the ability to write and being financially literate. In contrast, the marital status is insignificant. Happiness as one measure for well-being is significantly positive associated with financial literacy. Similarly, albeit only significant in the first model, people who are not depressed are also more likely to be financially literate. Moreover, the relationship between the economic status of the household and financial literacy is heterogeneous. Even though the asset index is statistically insignificant, we find that those with higher incomes are better financially educated. Having children at school-age also increases the probability of being more financially literate. Further, the exposure to financial concepts may vary by type of occupation and as such drives differences in financial literacy. Consistent with this theory, we observe that those in independent occupations have higher financial literacy and those in dependent occupation have lower financial literacy. Similar to Aterido et al. (2013), we interpret mobile phone ownership as a proxy for being more open to new ideas. Even if we control for household assets, the effect of mobile phone ownership on financial literacy is positive and statistically significant.

Importantly, the coefficient on the female dummy remains significant and about the same size as we introduce additional control variables. This gives a first indication that the gender gap in financial literacy is not only driven by confounding factors, but that other non-observables may also drive this gender gap. 
Coefficients in this section were estimated using simple OLS estimations. Hence, relationships described cannot be interpreted as causal. As a consequence and because variables that are potentially endogenous in these regressions are not significantly related to financial literacy, we will focus on only exogenous variables in later analyses.

- set Table 11 about here -

\subsection{Decomposition results}

Decomposition results are shown in Table 12. Both analyses estimate a linear probability model with the financial literacy index as outcome variable. The left hand side of the table does not contain a measure of wealth, whereas the right hand side does in form of the asset index. The table reports the coefficient estimates along with percentage shares. Standard errors are cluster-adjusted at the VSLG-level in order to account for intra-group correlation.

Overall, the mean of the financial literacy index is 2.833 for men and 2.363 for women. This yields a gender gap of 0.470 . The increase of 0.223 indicates that $47 \%$ of the gap stems from gender differences in endowments. The remaining $57 \%$ of the financial literacy gender gap can be attributed to gender differences in returns on these endowments.

The second and third panel of Table 12 show results of the detailed decomposition. We see that spelling as a proxy for educational attainment contributes about $18 \%$ to the gender gap in financial literacy. Furthermore, happiness as a measure of individual well-being also eliminates the gap in financial literacy by $5 \%$. Though statistically insignificant, improved symptoms of depression would also result in reduced gender differences in financial literacy. Further, mobile phone ownership can significantly reduce the gender gap by about $13 \%$.

The second analysis only differs to the first one by taking into account the economic status. We can see that this specification yields similar results and that mobile phone ownership remains its explanatory power. We, therefore, conclude that mobile phone ownership is not only an alternative measure for wealth but indicates something we interpret as openness to new ideas. Aterido et al. (2013) use a similar line of argumentation in order to explain the lower usage of formal banking services by women in Sub-Saharan Africa.

On the bottom line, this decomposition analysis shows that $47 \%$ of the financial literacy gender gap can be attributed to endowment effects. $21 \%$ of this can particularly be linked to personality traits such as openness (13\%), happiness (5\%), and depression 
$(3 \%)$. It already indicates that a large part of the gender gap has its roots in social environments. We argue that the remaining coefficient effect also captures some of these cultural and societal circumstances in women's lives. This point is common in the literature on gender gaps in general. Many authors have argued that gender differences are broadly consistent with gender stereotypes across cultures (Nolen-Hoeksema, 1987; American Psychological Association, 1994; Costa Jr et al., 2001; Thayer et al., 2003). Eagly (2013) explains that perceived differences between men and women might result from adoption of gender roles, which predetermine appropriate conduct for each gender.

- set Table 12 about here -

\section{Robustness}

This robustness section reports additional results that confirm our main findings. All results are presented in the Appendix. First, we use probit regression analysis to estimate the link between financial literacy and financial decision making (see Table B.2). The marginal effects are similar to the coefficients of the linear probability model, which is why we focus on OLS regressions in further robustness tests.

Table B.3 and Table B.4 repeat the analysis of women's involvement restricted to married women. Results are robust, albeit the income and energy decisions turn statistically insignificant in this specification, possibly due to the smaller sample size. This also holds for IV analysis in Table B.6.

In Table B.7 and Table B. 8 we change outcome variables to a factor score and a financial literacy dummy, respectively. Similar to van Rooij et al. (2011), the former is derived using an iterated principle factor analysis, followed by the Bartlett method (Bartlett, 1937). The estimated factor score of the first factor acts as a proxy for financial literacy. The latter is a dummy that is one if the respondent answered all financial literacy questions correctly. The patterns that emerge from both these tables are mostly consistent with our previous findings.

As mentioned previously, further controlling for VSLG fixed effects, all variables remain their direction; yet, many of them turn insignificant (see Table B.9, Table B.10 and Table B.11). The overall index counting the number of financial decisions, however, is still statistically significant thereby reinforcing the positive relationship between financial literacy and women's involvement in intra-household decisions.

We rerun most of these regressions also for IV analyses. Table B.12, Table B.13 and 
Table B.14 include VSLG fixed effects. The estimated directions remain the same, except for the expenditures on children. If we include an additional instrument, namely the distance to the nearest school from the respondent's home ${ }^{8}$, financial literacy is still significantly positive related to the overall index counting the number of financial decisions (see Table B.15 and Table B.16). The distance variable was generated using data from the National Institute of Statistics Rwanda on coordinates of all schools in Rwanda. We fed these coordinates together with the coordinates for each respondent's home into GQIS. We then used the software to calculate the distance to the nearest school for each respondent.

Section 5.2 shows regression results to get a first impression on drivers of the financial literacy gender gap. Table B.17 and Table B.18 rerun this model using alternative outcome measures of financial literacy. The results for the financial literacy factor score and financial literacy dummy are robust and the female dummy remains significantly negative.

As for the decomposition analysis, we show alternative results using (i) a linear probability model with the financial literacy factor score, and (ii) a non-linear probability model with the discrete financial literacy dummy. ${ }^{9}$ The left hand side of Table B.19 does not contain a measure of wealth, whereas the right hand side does in form of the asset index. The former decomposition analysis yields very similar results as in Table $12 .{ }^{10}$ In contrast, the endowment effect is reduced in the latter specification. A possible reason is that the dummy for only correct answers is too short-sighted. This measure captures less information on the variation of that kind.

\section{Conclusion}

This paper explores the relationship between financial literacy, gender and decision making power at home. Using both OLS and IV regression analysis, we first study whether financial literacy has an effect on the likelihood that women participate in decision making processes at home. Our findings indicate that women with higher financial literacy are more likely to report that they are involved in income, credit,

\footnotetext{
${ }^{8}$ These coordinates were saved during the survey and in most cases the interviews were conducted in the respondent's home. However, in few cases the interview coordinates might deviate from this because the interview was conducted in community buildings.

${ }^{9}$ For probit decomposition analysis, the mapping function, $F($.$) , is the Cumulative Distribution$ Function (CDF) of the standard normal distribution.

${ }^{10}$ This holds for both in total and in detail. The detailed results can be provided upon request.
} 
investment and expenditure decisions. Moreover, they are less likely to state that their husbands take the financial decision alone. This result is consistent with the hypothesis that financial literacy is a resource of empowerment and enhances women's involvement in intra-household decision making.

Following this, we use the multivariate decomposition technique to study mean outcome differences in financial literacy between men and women. We find that about $47 \%$ of the gender gap is explained by different endowments between men and women. The largest part of this is made up of differences in education and personality traits. $53 \%$ of the gap can be attributed to gender differences in returns on these endowments. Similar to Bucher-Koenen et al. (2017), Filipiak and Walle (2015) and Grohmann et al. (2016), we argue that it is reasonable to believe that this coefficient effect captures some of the societal and cultural circumstances in women's live that may hamper them to achieve higher financial literacy rates.

Clear policy lessons can be drawn from this research. First, it provides motivation to improve women's financial literacy, especially in developing countries. The decomposition analysis shows that improved educational levels may also result in higher financial literacy levels. Moreover, a large part of financial literacy differences between men and women is caused by personality traits. Financial literacy trainings should, therefore, take into account gender differences in personality and tailor content and delivery methods accordingly. Further, our results inform policymakers by highlighting that personal characteristics contribute about half to the financial literacy gender gap and that also cultural and societal factors are relevant. It is, therefore, possible that cross country studies or studies that look at personality traits and gender roles in more detail will provide further insights into the origins of the gender gap in financial literacy. 


\section{References}

Allendorf, K. (2007). Do women's land rights promote empowerment and child health in Nepal?, World Development 35(11): 1975-1988.

Alsop, R., Heinsohn, N. and Somma, A. (2005). Measuring empowerment: An analytic framework. In Power, Rights and Poverty: Concepts and Connections, Alsop, R. (ed). World Bank: Washington DC.

American Psychological Association (1994). Diagnostic and statistical manual of mental disorders, Washington.

Anderson, S. and Eswaran, M. (2009). What determines female autonomy? Evidence from Bangladesh, Journal of Development Economics 90(2): 179-191.

Ashraf, N., Karlan, D. and Yin, W. (2010). Female empowerment: Impact of a commitment savings product in the Philippines, World Development 38(3): 333344.

Aterido, R., Beck, T. and Iacovone, L. (2013). Access to finance in sub-Saharan Africa: Is there a gender gap?, World Development 47: 102-120.

Bartlett, M. S. (1937). The statistical conception of mental factors, British Journal of Psychology. General Section 28(1): 97-104.

Beijing Declaration (1995). Beijing Declaration and Platform for Action, Fourth World Conference on Women, 15 September. Available at: http://www.un.org/womenwatch/daw/beijing/platform/. [Accessed: October 17, 2017].

Blinder, A. S. (1973). Wage discrimination: Reduced form and structural estimates, Journal of Human Resources pp. 436-455.

Bobonis, G. J. (2009). Is the allocation of resources within the household efficient? New evidence from a randomized experiment, Journal of Political Economy $117(3): 453-503$.

Bucher-Koenen, T., Lusardi, A., Alessie, R. J. M. and van Rooij, M. C. J. (2017). How financially literate are women? An overview and new insights, Journal of Consumer Affairs 51(2): 255-283.

Cole, S., Sampson, T. and Zia, B. (2011). Prices or knowledge? What drives demand for financial services in emerging markets?, The Journal of Finance 66(6): 1933- 
1967.

Connelly, R., Roberts, K. and Zheng, Z. (2010). The impact of circular migration on the position of married women in rural China, Feminist Economics 16(1): 3-41.

Costa Jr, P., Terracciano, A. and McCrae, R. R. (2001). Gender differences in personality traits across cultures: Robust and surprising findings, Journal of Personality and Social Psychology 81(2): 322-331.

De Brauw, A., Gilligan, D. O., Hoddinott, J. and Roy, S. (2014). The impact of bolsa família on women's decision-making power, World Development 59: 487-504.

DFID (2010). Department for International Development. Agenda 2010: The turning point on poverty. Background paper, London. Available at: http://www.oecd.org/dac/gender-development/45249900.pdf. [Accessed: October $17,2017]$.

Doi, Y., McKenzie, D. and Zia, B. (2014). Who you train matters: Identifying combined effects of financial education on migrant households, Journal of Development Economics 109: 39-55.

Doss, C. (2013). Intrahousehold bargaining and resource allocation in developing countries, The World Bank Research Observer 28(1): 52-78.

Doss, C. R. (2001). Is risk fully pooled within the household? Evidence from Ghana, Economic Development and Cultural Change 50(1): 101-130.

Duflo, E. (2003). Grandmothers and granddaughters: Old-age pensions and intrahousehold allocation in South Africa, The World Bank Economic Review 17(1): 1-25.

Duflo, E. (2012). Women empowerment and economic development, Journal of Economic Literature 50(4): 1051-1079.

Duflo, E. and Udry, C. (2004). Intrahousehold resource allocation in Cote d'Ivoire: Social norms, separate accounts and consumption choices. National Bureau of Economic Research Working Paper No. 10498.

Eagly, A. H. (2013). Sex differences in social behavior: A social-role interpretation, Psychology Press.

Eaton, W. W., Smith, C., Ybarra, M., Muntaner, C. and Tien, A. (2004). Center for Epidemiologic Studies Depression Scale: review and revision (CESD and CESD-R)., In: Maruish ME, ed. The Use of Psychological Testing for Treatment Planning and 
Outcomes Assessment. 3rd ed. Mahwah, NJ: Lawrence Erlbaum pp. 363-377.

Fiala, N. and He, X. (2017). Unitary or Noncooperative Intrahousehold Model? Evidence from Couples in Uganda, The World Bank Economic Review 30: S77-S85.

Filipiak, U. and Walle, Y. M. (2015). The financial literacy gender gap: A question of nature or nurture? Courant Research Centre: Poverty, Equity and Growth Discussion Paper No. 176.

Fonseca, R., Mullen, K. J., Zamarro, G. and Zissimopoulos, J. (2012). What explains the gender gap in financial literacy? The role of household decision making, Journal of Consumer Affairs 46(1): 90-106.

Gathergood, J. (2012). Self-control, financial literacy and consumer over-indebtedness, Journal of Economic Psychology 33(3): 590-602.

Grohmann, A., Hübler, O., Kouwenberg, R. and Menkhoff, L. (2016). Financial literacy: Thai middle class women do not lag behind. DIW Working Paper No. 1615.

Hashemi, S. M., Schuler, S. R. and Riley, A. P. (1996). Rural credit programs and women's empowerment in Bangladesh, World Development 24(4): 635-653.

Hsu, J. W. (2016). Aging and strategic learning: The impact of spousal incentives on financial literacy, Journal of Human Resources 51(4): 1036-1067.

Kabeer, N. (1999). Resources, agency, achievements: Reflections on the measurement of women's empowerment, Development and Change 30(3): 435-464.

Kaiser, T. and Menkhoff, L. (2017). Does financial education impact financial literacy and financial behavior, and if so, when?, The World Bank Economic Review 31(3): 611-630.

Karlan, D., Savonitto, B., Thuysbaert, B. and Udry, C. (2017). Impact of savings groups on the lives of the poor, Proceedings of the National Academy of Sciences 114(12): 3079-3084.

Klapper, L. and Panos, G. A. (2011). Financial literacy and retirement planning: The Russian case, Journal of Pension Economics and Finance 10(4): 599-618.

Lusardi, A. and Mitchell, O. S. (2007). Baby boomer retirement security: The roles of planning, financial literacy, and housing wealth, Journal of Monetary Economics 54(1): 205-224. 
Lusardi, A. and Mitchell, O. S. (2011). Financial literacy and planning: Implications for retirement wellbeing. National Bureau of Economic Research Working Paper No. 17078.

Lusardi, A. and Mitchell, O. S. (2014). The economic importance of financial literacy: Theory and evidence, Journal of Economic Literature 52(1): 5-44.

Lusardi, A. and Tufano, P. (2015). Debt literacy, financial experiences, and overindebtedness, Journal of Pension Economics and Finance 14(4): 332-368.

Mabsout, R. and Van Staveren, I. (2010). Disentangling bargaining power from individual and household level to institutions: Evidence on women's position in Ethiopia, World Development 38(5): 783-796.

Mahdavi, M. and Horton, N. J. (2014). Financial knowledge among educated women: Room for improvement, Journal of Consumer Affairs 48(2): 403-417.

McElroy, M. B. and Horney, M. J. (1981). Nash-bargained household decisions: Toward a generalization of the theory of demand, International Economic Review pp. 333-349.

Moursund, A. and Kravdal, Ø. (2003). Individual and community effects of women's education and autonomy on contraceptive use in India, Population studies 57(3): 285-301.

NISR (2012). National Institute of Statistics of Rwanda. Rwanda Population and Housing Census 2012. Available at: http://microdata.statistics.gov.rw/index.php/catalog/65. [Accessed: February $23,2016]$.

Nolen-Hoeksema, S. (1987). Sex differences in unipolar depression: Evidence and theory, Psychological Bulletin 101(2): 259.

Oaxaca, R. (1973). Male-female wage differentials in urban labor markets, International Economic Review pp. 693-709.

Oaxaca, R. L. and Ransom, M. R. (1999). Identification in detailed wage decompositions, Review of Economics and Statistics 81(1): 154-157.

Radloff, L. S. (1977). The CES-D scale: A self-report depression scale for research in the general population, Applied Psychological Measurement 1(3): 385-401.

Sayinzoga, A., Bulte, E. H. and Lensink, R. (2015). Financial literacy and finan- 
cial behaviour: Experimental evidence from rural Rwanda, The Economic Journal 126(594): 1571-1599.

Sen, A. et al. (1999). Commodities and capabilities, OUP Catalogue .

Thayer, J. F., Rossy, L. A., Ruiz-Padial, E. and Johnsen, B. H. (2003). Gender differences in the relationship between emotional regulation and depressive symptoms, Cognitive Therapy and Research 27(3): 349-364.

Thomas, D. (1990). Intra-household resource allocation: An inferential approach, Journal of Human Resources pp. 635-664.

Thomas, D. (1993). The distribution of income and expenditure within the household, Annales d'Economie et de Statistique pp. 109-135.

UN (2015). Transforming our world: The 2030 Agenda for Sustainable Development. UN, General Assembly, A/RES/70/1, 21 October.

van Rooij, M. C. J., Lusardi, A. and Alessie, R. J. M. (2011). Financial literacy and stock market participation, Journal of Financial Economics 101(2): 449-472.

van Rooij, M. C. J., Lusardi, A. and Alessie, R. J. M. (2012). Financial literacy, retirement planning and household wealth, The Economic Journal 122(560): 449478.

$\mathrm{Xu}$, L. and Zia, B. (2012). Financial literacy around the world: An overview of the evidence with practical suggestions for the way forward. World Bank Policy Research Working Paper No. 6107.

Yun, M.-S. (2004). Decomposing differences in the first moment, Economics Letters 82(2): 275-280.

Yun, M.-S. (2008). Identification problem and detailed oaxaca decomposition: A general solution and inference, Journal of Economic and Social Measurement 33(1): 2738. 


\section{A. Tables and figures in text}

Table 1: Summary statistics of explanatory variables and gender differences

\begin{tabular}{|c|c|c|c|c|c|c|}
\hline & \multicolumn{2}{|c|}{ Female } & \multicolumn{2}{|c|}{ Male } & \multirow[b]{2}{*}{ Difference } & \multirow[b]{2}{*}{ p-Value } \\
\hline & Mean & $\mathrm{SD}$ & Mean & $\mathrm{SD}$ & & \\
\hline \multicolumn{7}{|l|}{ Socio-demographics } \\
\hline Age & 43.88 & 13.39 & 40.45 & 13.92 & $-3.431^{* * *}$ & 0.000 \\
\hline Spell & 0.57 & 0.50 & 0.72 & 0.45 & $0.151^{* * *}$ & 0.000 \\
\hline Single & 0.06 & 0.24 & 0.18 & 0.38 & $0.113^{* * *}$ & 0.000 \\
\hline Married & 0.67 & 0.47 & 0.77 & 0.42 & $0.110^{* * *}$ & 0.000 \\
\hline Widowed & 0.20 & 0.40 & 0.02 & 0.15 & $-0.178^{* * *}$ & 0.000 \\
\hline Divorced & 0.07 & 0.25 & 0.03 & 0.16 & $-0.042^{* * *}$ & 0.006 \\
\hline Happiness & 2.76 & 0.68 & 2.91 & 0.62 & $0.144^{* * *}$ & 0.001 \\
\hline Depression & 0.38 & 0.49 & 0.27 & 0.45 & $-0.110^{* * *}$ & 0.000 \\
\hline \multicolumn{7}{|l|}{ Household } \\
\hline HH size & 4.96 & 1.97 & 5.05 & 2.10 & 0.093 & 0.465 \\
\hline Children (0-5 years) & 0.64 & 0.79 & 0.83 & 0.90 & $0.191^{* * *}$ & 0.000 \\
\hline Children (6-12 years) & 1.07 & 1.05 & 1.05 & 1.10 & -0.021 & 0.757 \\
\hline Children (13-17 years) & 0.68 & 0.92 & 0.59 & 0.93 & -0.087 & 0.138 \\
\hline \multicolumn{7}{|l|}{ Income } \\
\hline Expenditure (Q1) & 0.27 & 0.45 & 0.17 & 0.38 & $-0.100^{* * *}$ & 0.000 \\
\hline Expenditure (Q2) & 0.24 & 0.43 & 0.28 & 0.45 & 0.038 & 0.172 \\
\hline Expenditure (Q3) & 0.25 & 0.44 & 0.24 & 0.43 & -0.017 & 0.529 \\
\hline Expenditure (Q4) & 0.23 & 0.42 & 0.31 & 0.46 & $0.080^{* * *}$ & 0.004 \\
\hline \multicolumn{7}{|l|}{ Assets } \\
\hline Assets Index & -0.10 & 1.53 & 0.35 & 1.53 & $0.454^{* * *}$ & 0.000 \\
\hline \multicolumn{7}{|l|}{ Openness } \\
\hline Owns Mobile Phone & 0.42 & 0.49 & 0.66 & 0.47 & $0.241^{* * *}$ & 0.000 \\
\hline
\end{tabular}

Note: ${ }^{*} \mathrm{p}<0.10,{ }^{* *} \mathrm{p}<0.05,{ }^{* * *} \mathrm{p}<0.01$ denote statistical significance. 
Table 2: Summary statistics of decision making and gender differences

\begin{tabular}{|c|c|c|c|c|c|c|}
\hline & \multicolumn{2}{|c|}{ Female } & \multicolumn{2}{|c|}{ Male } & \multirow[b]{2}{*}{ Difference } & \multirow[b]{2}{*}{ p-Value } \\
\hline & Mean & $\mathrm{SD}$ & Mean & $\mathrm{SD}$ & & \\
\hline Income self & 0.41 & 0.49 & 0.29 & 0.45 & $-0.12 * * *$ & 0.000 \\
\hline Income both & 0.46 & 0.50 & 0.63 & 0.48 & $0.18 * * *$ & 0.000 \\
\hline Income spouse & 0.11 & 0.32 & 0.06 & 0.24 & $-0.06 * * *$ & 0.004 \\
\hline Income invo & 0.87 & 0.33 & 0.92 & 0.27 & $0.05 * *$ & 0.011 \\
\hline Credit self & 0.41 & 0.49 & 0.27 & 0.44 & $-0.14 * * *$ & 0.000 \\
\hline Credit both & 0.55 & 0.50 & 0.69 & 0.46 & $0.14 * * *$ & 0.000 \\
\hline Credit spouse & 0.03 & 0.17 & 0.03 & 0.16 & -0.00 & 0.799 \\
\hline Credit invo & 0.96 & 0.19 & 0.96 & 0.19 & -0.00 & 0.936 \\
\hline Invest self & 0.42 & 0.49 & 0.27 & 0.45 & $-0.15 * * *$ & 0.000 \\
\hline Invest both & 0.51 & 0.50 & 0.66 & 0.47 & $0.15 * * *$ & 0.000 \\
\hline Invest spouse & 0.05 & 0.22 & 0.03 & 0.18 & -0.02 & 0.182 \\
\hline Invest invo & 0.93 & 0.25 & 0.93 & 0.25 & -0.00 & 0.805 \\
\hline Food self & 0.58 & 0.49 & 0.25 & 0.43 & $-0.33 * * *$ & 0.000 \\
\hline Food both & 0.36 & 0.48 & 0.50 & 0.50 & $0.14 * * *$ & 0.000 \\
\hline Food spouse & 0.05 & 0.21 & 0.21 & 0.41 & $0.16 * * *$ & 0.000 \\
\hline Food invo & 0.93 & 0.25 & 0.74 & 0.44 & $-0.19 * * *$ & 0.000 \\
\hline Own health self & 0.63 & 0.48 & 0.56 & 0.50 & $-0.07 * *$ & 0.035 \\
\hline Own health both & 0.31 & 0.46 & 0.37 & 0.48 & $0.05 *$ & 0.071 \\
\hline Own health spouse & 0.05 & 0.21 & 0.06 & 0.24 & 0.01 & 0.448 \\
\hline Own health invo & 0.94 & 0.23 & 0.93 & 0.25 & -0.01 & 0.443 \\
\hline Own clothes self & 0.61 & 0.49 & 0.56 & 0.50 & -0.05 & 0.141 \\
\hline Own clothes both & 0.33 & 0.47 & 0.39 & 0.49 & $0.05 *$ & 0.068 \\
\hline Own clothes spouse & 0.05 & 0.22 & 0.04 & 0.20 & -0.01 & 0.429 \\
\hline Own clothes invo & 0.94 & 0.23 & 0.95 & 0.21 & 0.01 & 0.518 \\
\hline Energy self & 0.50 & 0.50 & 0.33 & 0.47 & $-0.17 * * *$ & 0.000 \\
\hline Energy both & 0.36 & 0.48 & 0.47 & 0.50 & $0.11 * * *$ & 0.001 \\
\hline Energy spouse & 0.12 & 0.32 & 0.17 & 0.37 & $0.05 * *$ & 0.026 \\
\hline Energy invo & 0.86 & 0.35 & 0.80 & 0.40 & $-0.06 * * *$ & 0.005 \\
\hline Child's health self & 0.42 & 0.49 & 0.12 & 0.33 & $-0.30 * * *$ & 0.000 \\
\hline Child's health both & 0.54 & 0.50 & 0.81 & 0.40 & $0.27 * * *$ & 0.000 \\
\hline Child's health spouse & 0.04 & 0.20 & 0.06 & 0.24 & 0.02 & 0.137 \\
\hline Child's health invo & 0.95 & 0.21 & 0.93 & 0.26 & -0.02 & 0.124 \\
\hline Child's clothes self & 0.45 & 0.50 & 0.13 & 0.34 & $-0.32 * * *$ & 0.000 \\
\hline Child's clothes both & 0.51 & 0.50 & 0.77 & 0.42 & $0.26 * * *$ & 0.000 \\
\hline Child's clothes spouse & 0.04 & 0.19 & 0.09 & 0.29 & $0.05 * * *$ & 0.000 \\
\hline Child's clothes invo & 0.96 & 0.20 & 0.90 & 0.30 & $-0.06 * * *$ & 0.000 \\
\hline Observations & 1081 & & 324 & & 1405 & \\
\hline
\end{tabular}

Note: ${ }^{*} \mathrm{p}<0.10,{ }^{* *} \mathrm{p}<0.05,{ }^{* * *} \mathrm{p}<0.01$ denote statistical significance. 
Table 3: Distribution of financial literacy questions divided by gender

\begin{tabular}{lrrr}
\hline & Female (\%) & Male (\%) & Total (\%) \\
\hline Compound interest & & & \\
Less than RWF 10.200 & 7.68 & 6.48 & 7.40 \\
Exactly RWF 10.200 & 5.64 & 2.16 & 4.84 \\
More than RWF 10.200 (correct) & 60.78 & 76.85 & 64.48 \\
Don't know & 25.90 & 14.51 & 23.27 \\
Inflation & & & \\
Less (correct) & 56.24 & 66.67 & 58.65 \\
Same & 3.70 & 4.01 & 3.77 \\
More & 17.58 & 19.14 & 17.94 \\
Don't know & 22.48 & 10.19 & 19.64 \\
Risk diversification & & & \\
One crop & 25.44 & 20.06 & 24.20 \\
Multiple crops (correct) & 73.27 & 78.70 & 74.52 \\
Don't know & 1.30 & 1.23 & 1.28 \\
Borrowing decision & & & \\
RWF 60.000 & 32.93 & 28.09 & 31.81 \\
RWF 50.000 + 15\% (correct) & 45.33 & 61.11 & 48.97 \\
Don't know & 21.74 & 10.80 & 19.22 \\
Cross-question consistency & & & \\
Wrong: Interest and Inflation & 55.23 & 42.59 & 52.31 \\
Correct: Interest and Inflation & 44.77 & 57.41 & 47.69 \\
\hline
\end{tabular}

Note: The table shows results on each financial literacy question. 
Table 4: Distribution of financial literacy questions divided by gender - extended

\begin{tabular}{|c|c|c|c|c|c|c|}
\hline & \multicolumn{2}{|c|}{ Female } & \multicolumn{2}{|c|}{ Male } & \multirow[b]{2}{*}{ Difference } & \multirow[b]{2}{*}{ p-Value } \\
\hline & Freq. & Prop. & Freq. & Prop. & & \\
\hline All questions correct & 234 & 0.2165 & 110 & 0.3395 & $-0.1230^{* * *}$ & 0.0000 \\
\hline Zero correct answers & 75 & 0.0694 & 11 & 0.0340 & $0.0354^{* *}$ & 0.0196 \\
\hline At least one don't know & 375 & 0.3469 & 60 & 0.1852 & $0.1617^{* * *}$ & 0.0000 \\
\hline All don't know & 6 & 0.0056 & 0 & 0.0000 & 0.0055 & 0.1792 \\
\hline \multirow[t]{3}{*}{ Total Obs. } & 1081 & & 324 & & & \\
\hline & \multicolumn{2}{|c|}{ Female } & \multicolumn{2}{|c|}{ Male } & & \\
\hline & Mean & $\mathrm{SD}$ & Mean & $\mathrm{SD}$ & Difference & p-Value \\
\hline FL index & 2.3562 & 1.2217 & 2.8333 & 1.2253 & $-0.4772^{* * *}$ & 0.0000 \\
\hline FL factor score & -0.1092 & 1.2628 & 0.3644 & 1.1284 & $-0.4736^{* * *}$ & 0.0000 \\
\hline FL dummy & 0.2165 & 0.4120 & 0.3395 & 0.4743 & $-0.1230^{* * *}$ & 0.0000 \\
\hline
\end{tabular}

Note: ${ }^{*} \mathrm{p}<0.10,{ }^{* *} \mathrm{p}<0.05,{ }^{* * *} \mathrm{p}<0.01$ denote statistical significance. 
Table 5: OLS with FL Index

\begin{tabular}{|c|c|c|c|c|c|c|c|}
\hline & $\begin{array}{c}(1) \\
\text { Income decision } \\
\text { involved } \\
\beta / \mathrm{SE}\end{array}$ & $\begin{array}{c}(2) \\
\text { Income decision } \\
\text { spouse } \\
\beta / \mathrm{SE}\end{array}$ & $\begin{array}{c}(3) \\
\text { Credit decision } \\
\text { involved } \\
\beta / \mathrm{SE}\end{array}$ & $\begin{array}{c}(4) \\
\text { Credit decision } \\
\text { spouse } \\
\beta / \mathrm{SE}\end{array}$ & $\begin{array}{c}(5) \\
\text { Investment decision } \\
\text { involved } \\
\beta / \mathrm{SE}\end{array}$ & $\begin{array}{c}(6) \\
\text { Investment decision } \\
\text { spouse } \\
\beta / \mathrm{SE}\end{array}$ & $\begin{array}{c}(7) \\
\text { Number decisions } \\
\text { involved in } \\
\beta / \mathrm{SE}\end{array}$ \\
\hline Financial literacy index & $0.020^{* *}$ & -0.014 & $0.012^{* *}$ & $-0.014^{* *}$ & $0.017^{* *}$ & $-0.021^{* *}$ & $0.055^{* * *}$ \\
\hline \multirow[t]{2}{*}{ Age } & $0.012^{*}$ & -0.002 & $0.009^{* *}$ & -0.005 & $0.015^{* * *}$ & $-0.012^{*}$ & $0.033^{* *}$ \\
\hline & $(0.007)$ & $(0.010)$ & $(0.004)$ & $(0.005)$ & $(0.005)$ & $(0.007)$ & $(0.014)$ \\
\hline \multirow[t]{2}{*}{$\mathrm{Age}^{2}$} & -0.000 & -0.000 & $-0.000^{* *}$ & 0.000 & $-0.000^{* *}$ & 0.000 & $-0.000^{*}$ \\
\hline & $(0.000)$ & $(0.000)$ & $(0.000)$ & $(0.000)$ & $(0.000)$ & $(0.000)$ & $(0.000)$ \\
\hline Spell & $\begin{array}{c}0.028 \\
(0.025)\end{array}$ & $\begin{array}{c}-0.046 \\
(0.035)\end{array}$ & $\begin{array}{c}-0.000 \\
(0.015)\end{array}$ & $\begin{array}{c}-0.010 \\
(0.022)\end{array}$ & $\begin{array}{c}0.011 \\
(0.018)\end{array}$ & $\begin{array}{c}-0.019 \\
(0.025)\end{array}$ & $\begin{array}{c}0.039 \\
(0.047)\end{array}$ \\
\hline Married & $\begin{array}{c}-0.021 \\
(0.046)\end{array}$ & & $\begin{array}{c}-0.020 \\
(0.024)\end{array}$ & & $\begin{array}{l}-0.107^{* * *} \\
(0.032)\end{array}$ & & $\begin{array}{c}-0.115 \\
(0.077)\end{array}$ \\
\hline \multirow[t]{2}{*}{ Widowed } & $0.085^{*}$ & & 0.004 & & $-0.075^{* *}$ & & 0.083 \\
\hline & $(0.050)$ & & $(0.025)$ & & $(0.033)$ & & $(0.085)$ \\
\hline \multirow[t]{2}{*}{ Divorced } & $0.116^{* *}$ & & -0.010 & & $-0.069^{* *}$ & & 0.105 \\
\hline & $\begin{array}{c}(0.047) \\
-0.022^{* *}\end{array}$ & 0.013 & $\begin{array}{l}(0.030) \\
-0.005\end{array}$ & -0.001 & $-0.016^{* *}$ & 0.007 & $-0.041^{* * *}$ \\
\hline HH size & $(0.009)$ & $(0.013)$ & $(0.004)$ & $(0.005)$ & $(0.006)$ & $(0.008)$ & $(0.015)$ \\
\hline \multirow[t]{2}{*}{ Children (0-5 years) } & 0.026 & -0.019 & 0.011 & -0.014 & 0.020 & -0.025 & $0.053^{*}$ \\
\hline & $(0.018)$ & $(0.024)$ & $(0.009)$ & $(0.012)$ & $(0.013)$ & $(0.016)$ & $(0.028)$ \\
\hline \multirow[t]{2}{*}{ Children (6-12 years) } & 0.015 & -0.012 & -0.007 & 0.013 & $0.022^{* *}$ & -0.021 & 0.034 \\
\hline & $(0.012)$ & $(0.016)$ & $(0.008)$ & $(0.010)$ & $(0.010)$ & $(0.013)$ & $(0.023)$ \\
\hline \multirow[t]{2}{*}{ Children (13-17 years) } & 0.012 & -0.010 & 0.003 & -0.003 & 0.010 & -0.000 & 0.027 \\
\hline & $(0.014)$ & $(0.019)$ & $(0.006)$ & $(0.007)$ & $(0.009)$ & $(0.010)$ & $(0.021)$ \\
\hline \multirow[t]{2}{*}{ Expenditure (Q2) } & $0.044^{*}$ & -0.066 & 0.007 & -0.008 & 0.022 & -0.032 & $0.094^{*}$ \\
\hline & $(0.024)$ & $(0.043)$ & $(0.015)$ & $(0.026)$ & $(0.020)$ & $(0.031)$ & $(0.049)$ \\
\hline \multirow[t]{2}{*}{ Expenditure (Q3) } & 0.011 & -0.045 & -0.008 & 0.002 & -0.000 & 0.003 & 0.036 \\
\hline & $(0.031)$ & $(0.047)$ & $(0.019)$ & $(0.027)$ & $(0.023)$ & $(0.034)$ & $(0.059)$ \\
\hline \multirow[t]{2}{*}{ Expenditure (Q4) } & 0.038 & $-0.102^{* *}$ & 0.006 & -0.011 & -0.016 & 0.016 & 0.064 \\
\hline & $(0.031)$ & $(0.043)$ & $(0.019)$ & $(0.026)$ & $(0.026)$ & $(0.034)$ & $(0.057)$ \\
\hline \multirow[t]{2}{*}{ Asset index } & -0.008 & 0.007 & 0.000 & 0.005 & 0.003 & -0.001 & -0.006 \\
\hline & $(0.008)$ & $(0.009)$ & $(0.004)$ & $(0.005)$ & $(0.006)$ & $(0.007)$ & $(0.014)$ \\
\hline Observations & 1057 & 705 & 1057 & 705 & 1033 & 686 & 1057 \\
\hline$R^{2}$ & 0.063 & 0.020 & 0.025 & 0.017 & 0.042 & 0.038 & 0.071 \\
\hline
\end{tabular}

Note: The table reports coefficients of multivariate regressions with standard errors clustered at VSLG level in brackets. ${ }^{*} \mathrm{p}<0.10,{ }^{* *} \mathrm{p}<0.05,{ }^{* * *} \mathrm{p}<0.01$ denote statistical significance. The outcome variable in column 1,3 and 5 is one if women are involved in the decision. The outcome variable in columns 2,4 and 6 is one if their husbands decide alone. Column 7 counts the number of financial decisions women are involved in. Financial literacy is an index which is generated by giving one point for each financial literacy question answered correctly. 
Table 6: OLS with FL Index (Household)

\begin{tabular}{|c|c|c|c|c|c|c|c|c|}
\hline & $\begin{array}{c}(1) \\
\text { Food } \\
\text { involved } \\
\beta / \mathrm{SE}\end{array}$ & $\begin{array}{c}(2) \\
\text { Food } \\
\text { spouse } \\
\beta / \mathrm{SE}\end{array}$ & $\begin{array}{c}(3) \\
\text { Own health } \\
\text { involved } \\
\beta / \mathrm{SE}\end{array}$ & $\begin{array}{c}(4) \\
\text { Own health } \\
\text { spouse } \\
\beta / \mathrm{SE}\end{array}$ & $\begin{array}{c}(5) \\
\text { Own clothes } \\
\text { involved } \\
\beta / \mathrm{SE}\end{array}$ & $\begin{array}{c}(6) \\
\text { Own clothes } \\
\text { spouse } \\
\beta / \mathrm{SE}\end{array}$ & $\begin{array}{c}(7) \\
\text { Energy } \\
\text { involved } \\
\beta / \mathrm{SE}\end{array}$ & $\begin{array}{c}(8) \\
\text { Energy } \\
\text { spouse } \\
\beta / \mathrm{SE}\end{array}$ \\
\hline Financial literacy index & $\begin{array}{l}0.015^{* *} \\
(0.007)\end{array}$ & $\begin{array}{c}-0.017^{*} \\
(0.010)\end{array}$ & $\begin{array}{l}0.018^{* * * *} \\
(0.007)\end{array}$ & $\begin{array}{c}-0.016^{*} \\
(0.010)\end{array}$ & $\begin{array}{l}0.014^{* *} \\
(0.006)\end{array}$ & $\begin{array}{c}-0.020^{* *} \\
(0.009)\end{array}$ & $\begin{array}{c}0.015^{*} \\
(0.009)\end{array}$ & $\begin{array}{c}-0.018 \\
(0.012)\end{array}$ \\
\hline Age & $\begin{array}{l}0.018^{* * *} \\
(0.005)\end{array}$ & $\begin{array}{r}-0.010 \\
(0.007)\end{array}$ & $\begin{array}{l}0.012^{* *} \\
(0.005)\end{array}$ & $\begin{array}{c}-0.004 \\
(0.007)\end{array}$ & $\begin{array}{l}0.008^{* *} \\
(0.004)\end{array}$ & $\begin{array}{c}-0.012^{*} \\
(0.007)\end{array}$ & $\begin{array}{l}0.022^{* * *} \\
(0.006)\end{array}$ & $\begin{array}{c}-0.020^{* *} \\
(0.010)\end{array}$ \\
\hline $\mathrm{Age}^{2}$ & $\begin{array}{c}-0.000^{* * *} \\
(0.000)\end{array}$ & $\begin{array}{c}0.000 \\
(0.000)\end{array}$ & $\begin{array}{c}-0.000^{* *} \\
(0.000)\end{array}$ & $\begin{array}{c}0.000 \\
(0.000)\end{array}$ & $\begin{array}{c}-0.000 \\
(0.000)\end{array}$ & $\begin{array}{c}0.000 \\
(0.000)\end{array}$ & $\begin{array}{c}-0.000^{* * *} \\
(0.000)\end{array}$ & $\begin{array}{c}0.000^{*} \\
(0.000)\end{array}$ \\
\hline Spell & $\begin{array}{c}0.017 \\
(0.018)\end{array}$ & $\begin{array}{c}-0.034 \\
(0.024)\end{array}$ & $\begin{array}{c}-0.009 \\
(0.018)\end{array}$ & $\begin{array}{c}0.002 \\
(0.025)\end{array}$ & $\begin{array}{c}0.007 \\
(0.017)\end{array}$ & $\begin{array}{c}-0.020 \\
(0.023)\end{array}$ & $\begin{array}{c}0.045^{*} \\
(0.026)\end{array}$ & $\begin{array}{c}-0.068^{*} \\
(0.037)\end{array}$ \\
\hline Married & $\begin{array}{c}0.100^{*} \\
(0.053)\end{array}$ & & $\begin{array}{c}-0.019 \\
(0.043)\end{array}$ & & $\begin{array}{c}-0.077^{* *} \\
(0.037)\end{array}$ & & $\begin{array}{c}0.022 \\
(0.057)\end{array}$ & \\
\hline Widowed & $\begin{array}{c}0.131^{* *} \\
(0.052)\end{array}$ & & $\begin{array}{c}0.026 \\
(0.043)\end{array}$ & & $\begin{array}{c}-0.042 \\
(0.039)\end{array}$ & & $\begin{array}{c}0.139^{* *} \\
(0.061)\end{array}$ & \\
\hline Divorced & $\begin{array}{l}0.130^{* *} \\
(0.053)\end{array}$ & & $\begin{array}{c}0.038 \\
(0.041)\end{array}$ & & $\begin{array}{c}-0.036 \\
(0.040)\end{array}$ & & $\begin{array}{l}0.149^{* *} \\
(0.058)\end{array}$ & \\
\hline HH size & $\begin{array}{c}-0.020^{* * * *} \\
(0.007)\end{array}$ & $\begin{array}{c}-0.003 \\
(0.008)\end{array}$ & $\begin{array}{c}-0.008 \\
(0.007)\end{array}$ & $\begin{array}{c}-0.002 \\
(0.008)\end{array}$ & $\begin{array}{c}-0.003 \\
(0.006)\end{array}$ & $\begin{array}{c}0.004 \\
(0.009)\end{array}$ & $\begin{array}{c}-0.023^{* *} \\
(0.009)\end{array}$ & $\begin{array}{c}-0.011 \\
(0.012)\end{array}$ \\
\hline Children (0-5 years) & $\begin{array}{c}0.016 \\
(0.012)\end{array}$ & $\begin{array}{c}0.004 \\
(0.017)\end{array}$ & $\begin{array}{c}0.006 \\
(0.012)\end{array}$ & $\begin{array}{c}-0.006 \\
(0.017)\end{array}$ & $\begin{array}{c}0.013 \\
(0.011)\end{array}$ & $\begin{array}{c}-0.035^{* *} \\
(0.015)\end{array}$ & $\begin{array}{c}0.023 \\
(0.016)\end{array}$ & $\begin{array}{c}0.012 \\
(0.021)\end{array}$ \\
\hline Children (6-12 years) & $\begin{array}{c}0.014 \\
(0.009)\end{array}$ & $\begin{array}{c}0.004 \\
(0.011)\end{array}$ & $\begin{array}{c}0.007 \\
(0.008)\end{array}$ & $\begin{array}{c}-0.002 \\
(0.011)\end{array}$ & $\begin{array}{c}0.008 \\
(0.009)\end{array}$ & $\begin{array}{c}-0.006 \\
(0.013)\end{array}$ & $\begin{array}{c}0.021^{*} \\
(0.012)\end{array}$ & $\begin{array}{c}0.003 \\
(0.015)\end{array}$ \\
\hline Children (13-17 years) & $\begin{array}{c}0.010 \\
(0.009)\end{array}$ & $\begin{array}{c}0.000 \\
(0.010)\end{array}$ & $\begin{array}{c}0.001 \\
(0.009)\end{array}$ & $\begin{array}{c}-0.001 \\
(0.012)\end{array}$ & $\begin{array}{l}0.015^{* *} \\
(0.007)\end{array}$ & $\begin{array}{c}-0.025^{* *} \\
(0.011)\end{array}$ & $\begin{array}{c}0.003 \\
(0.015)\end{array}$ & $\begin{array}{c}0.030 \\
(0.021)\end{array}$ \\
\hline Expenditure (Q2) & $\begin{array}{c}0.018 \\
(0.020)\end{array}$ & $\begin{array}{c}-0.031 \\
(0.032)\end{array}$ & $\begin{array}{l}0.037^{*} \\
(0.020)\end{array}$ & $\begin{array}{r}-0.054^{*} \\
(0.033)\end{array}$ & $\begin{array}{c}0.023 \\
(0.019)\end{array}$ & $\begin{array}{c}-0.051 \\
(0.031)\end{array}$ & $\begin{array}{c}0.009 \\
(0.029)\end{array}$ & $\begin{array}{c}-0.027 \\
(0.049)\end{array}$ \\
\hline Expenditure (Q3) & $\begin{array}{c}0.018 \\
(0.022)\end{array}$ & $\begin{array}{c}-0.031 \\
(0.031)\end{array}$ & $\begin{array}{c}0.020 \\
(0.022)\end{array}$ & $\begin{array}{c}-0.035 \\
(0.033)\end{array}$ & $\begin{array}{c}-0.011 \\
(0.022)\end{array}$ & $\begin{array}{c}-0.013 \\
(0.032)\end{array}$ & $\begin{array}{c}-0.001 \\
(0.029)\end{array}$ & $\begin{array}{c}-0.005 \\
(0.043)\end{array}$ \\
\hline Expenditure (Q4) & $\begin{array}{c}0.011 \\
(0.024)\end{array}$ & $\begin{array}{c}-0.014 \\
(0.032)\end{array}$ & $\begin{array}{c}0.019 \\
(0.024)\end{array}$ & $\begin{array}{c}-0.028 \\
(0.034)\end{array}$ & $\begin{array}{c}0.009 \\
(0.022)\end{array}$ & $\begin{array}{c}-0.023 \\
(0.032)\end{array}$ & $\begin{array}{c}0.010 \\
(0.032)\end{array}$ & $\begin{array}{c}-0.046 \\
(0.044)\end{array}$ \\
\hline Asset index & $\begin{array}{c}-0.001 \\
(0.006)\end{array}$ & $\begin{array}{c}0.001 \\
(0.007)\end{array}$ & $\begin{array}{c}0.004 \\
(0.005)\end{array}$ & $\begin{array}{c}-0.004 \\
(0.007)\end{array}$ & $\begin{array}{c}-0.008 \\
(0.006)\end{array}$ & $\begin{array}{c}0.010 \\
(0.008)\end{array}$ & $\begin{array}{c}-0.014 \\
(0.009)\end{array}$ & $\begin{array}{c}0.024^{* *} \\
(0.011)\end{array}$ \\
\hline $\begin{array}{l}\text { Observations } \\
R^{2}\end{array}$ & $\begin{array}{c}1056 \\
0.081\end{array}$ & $\begin{array}{l}704 \\
0.026\end{array}$ & $\begin{array}{c}1057 \\
0.040\end{array}$ & $\begin{array}{l}705 \\
0.023\end{array}$ & $\begin{array}{c}1057 \\
0.043\end{array}$ & $\begin{array}{l}705 \\
0.053\end{array}$ & $\begin{array}{l}1055 \\
0.077\end{array}$ & $\begin{array}{l}704 \\
0.029\end{array}$ \\
\hline
\end{tabular}

Note: The table reports coefficients of multivariate regressions with standard errors clustered at VSLG level in brackets. $* \mathrm{p}<0.10, * * \mathrm{p}<0.05, * * * \mathrm{p}<0.01$ denote statistical significance. Financial literacy is an index which is generated by giving one point for each financial literacy question answered correctly. 
Table 7: OLS with FL Index (Children)

\begin{tabular}{|c|c|c|c|c|c|}
\hline & $\begin{array}{c}(1) \\
\text { Children health } \\
\text { involved } \\
\beta / \mathrm{SE}\end{array}$ & $\begin{array}{c}(2) \\
\text { Children health } \\
\text { spouse } \\
\beta / \mathrm{SE}\end{array}$ & $\begin{array}{c}(3) \\
\text { Children clothes } \\
\text { involved } \\
\beta / \mathrm{SE}\end{array}$ & $\begin{array}{c}(4) \\
\text { Children clothes } \\
\text { spouse } \\
\beta / \mathrm{SE}\end{array}$ & $\begin{array}{c}(5) \\
\text { Number decisions } \\
\text { involved in } \\
\beta / \mathrm{SE}\end{array}$ \\
\hline Financial literacy index & $\begin{array}{c}0.005 \\
(0.007)\end{array}$ & $\begin{array}{c}-0.003 \\
(0.009)\end{array}$ & $\begin{array}{l}0.006 \\
(0.007)\end{array}$ & $\begin{array}{r}-0.006 \\
(0.009)\end{array}$ & $\begin{array}{l}0.069^{* *} \\
(0.033)\end{array}$ \\
\hline Age & $\begin{array}{l}0.011^{*} \\
(0.007)\end{array}$ & $\begin{array}{c}0.002 \\
(0.006)\end{array}$ & $\begin{array}{c}0.010 \\
(0.007)\end{array}$ & $\begin{array}{c}-0.000 \\
(0.006)\end{array}$ & $\begin{array}{l}0.102^{* * *} \\
(0.023)\end{array}$ \\
\hline $\mathrm{Age}^{2}$ & $\begin{array}{c}-0.000 \\
(0.000)\end{array}$ & $\begin{array}{c}-0.000 \\
(0.000)\end{array}$ & $\begin{array}{c}-0.000 \\
(0.000)\end{array}$ & $\begin{array}{c}-0.000 \\
(0.000)\end{array}$ & $\begin{array}{c}-0.001 * * * \\
(0.000)\end{array}$ \\
\hline Spell & $\begin{array}{c}0.014 \\
(0.019)\end{array}$ & $\begin{array}{c}-0.027 \\
(0.024)\end{array}$ & $\begin{array}{c}0.013 \\
(0.018)\end{array}$ & $\begin{array}{c}-0.020 \\
(0.023)\end{array}$ & $\begin{array}{c}0.132 \\
(0.082)\end{array}$ \\
\hline Married & $\begin{array}{l}0.020 \\
(0.051)\end{array}$ & & $\begin{array}{c}-0.010 \\
(0.044)\end{array}$ & & $\begin{array}{c}0.304 \\
(0.205)\end{array}$ \\
\hline Widowed & $\begin{array}{l}0.048 \\
(0.050)\end{array}$ & & $\begin{array}{c}0.023 \\
(0.046)\end{array}$ & & $\begin{array}{l}0.450^{* *} \\
(0.220)\end{array}$ \\
\hline Divorced & $\begin{array}{c}0.047 \\
(0.051)\end{array}$ & & $\begin{array}{c}-0.000 \\
(0.049)\end{array}$ & & $\begin{array}{l}0.504^{* *} \\
(0.236)\end{array}$ \\
\hline $\mathrm{HH}$ size & $\begin{array}{c}-0.011 \\
(0.007)\end{array}$ & $\begin{array}{c}0.004 \\
(0.008)\end{array}$ & $\begin{array}{c}-0.006 \\
(0.006)\end{array}$ & $\begin{array}{r}-0.000 \\
(0.007)\end{array}$ & $\begin{array}{c}-0.126^{* * *} \\
(0.033)\end{array}$ \\
\hline Children (0-5 years) & $\begin{array}{c}0.011 \\
(0.010)\end{array}$ & $\begin{array}{c}-0.005 \\
(0.014)\end{array}$ & $\begin{array}{c}0.006 \\
(0.010)\end{array}$ & $\begin{array}{c}-0.009 \\
(0.012)\end{array}$ & $\begin{array}{l}0.442^{* * *} \\
(0.049)\end{array}$ \\
\hline Children (6-12 years) & $\begin{array}{c}0.003 \\
(0.008)\end{array}$ & $\begin{array}{c}-0.002 \\
(0.010)\end{array}$ & $\begin{array}{c}0.005 \\
(0.009)\end{array}$ & $\begin{array}{c}0.000 \\
(0.010)\end{array}$ & $\begin{array}{l}0.325^{* * *} \\
(0.039)\end{array}$ \\
\hline Children (13-17 years) & $\begin{array}{c}-0.001 \\
(0.008)\end{array}$ & $\begin{array}{c}-0.004 \\
(0.009)\end{array}$ & $\begin{array}{c}0.003 \\
(0.007)\end{array}$ & $\begin{array}{c}-0.008 \\
(0.009)\end{array}$ & $\begin{array}{l}0.303^{* * *} \\
(0.041)\end{array}$ \\
\hline Expenditure (Q2) & $\begin{array}{c}0.015 \\
(0.020)\end{array}$ & $\begin{array}{c}-0.025 \\
(0.029)\end{array}$ & $\begin{array}{c}-0.012 \\
(0.020)\end{array}$ & $\begin{array}{c}0.016 \\
(0.029)\end{array}$ & $\begin{array}{c}0.094 \\
(0.102)\end{array}$ \\
\hline Expenditure (Q3) & $\begin{array}{c}0.003 \\
(0.022)\end{array}$ & $\begin{array}{c}-0.020 \\
(0.031)\end{array}$ & $\begin{array}{c}-0.018 \\
(0.021)\end{array}$ & $\begin{array}{c}0.004 \\
(0.028)\end{array}$ & $\begin{array}{c}0.093 \\
(0.106)\end{array}$ \\
\hline Expenditure (Q4) & $\begin{array}{c}0.031 \\
(0.022)\end{array}$ & $\begin{array}{c}-0.044 \\
(0.030)\end{array}$ & $\begin{array}{c}0.020 \\
(0.019)\end{array}$ & $\begin{array}{c}-0.023 \\
(0.026)\end{array}$ & $\begin{array}{c}0.154 \\
(0.110)\end{array}$ \\
\hline Asset index & $\begin{array}{c}-0.003 \\
(0.006)\end{array}$ & $\begin{array}{c}0.002 \\
(0.006)\end{array}$ & $\begin{array}{l}0.000 \\
(0.005)\end{array}$ & $\begin{array}{c}0.001 \\
(0.006)\end{array}$ & $\begin{array}{c}-0.029 \\
(0.026)\end{array}$ \\
\hline $\begin{array}{l}\text { Observations } \\
R^{2}\end{array}$ & $\begin{array}{l}863 \\
0.023\end{array}$ & $\begin{array}{l}634 \\
0.011\end{array}$ & $\begin{array}{l}862 \\
0.022\end{array}$ & $\begin{array}{l}634 \\
0.013\end{array}$ & 1057 \\
\hline
\end{tabular}

Note: The table reports coefficients of multivariate regressions with standard errors clustered at VSLG level in brackets. $* \mathrm{p}<0.10, * * \mathrm{p}<0.05, * * * \mathrm{p}<0.01$ denote statistical significance. Financial literacy is an index which is generated by giving one point for each financial literacy question answered correctly. 
Table 8: IV with FL Index

\begin{tabular}{|c|c|c|c|c|c|c|c|}
\hline & $\begin{array}{c}(1) \\
\text { Income decision } \\
\text { involved } \\
\beta / \mathrm{SE}\end{array}$ & $\begin{array}{c}(2) \\
\text { Income decision } \\
\text { spouse } \\
\beta / \mathrm{SE}\end{array}$ & $\begin{array}{c}(3) \\
\text { Credit decision } \\
\text { involved } \\
\beta / \mathrm{SE}\end{array}$ & $\begin{array}{c}(4) \\
\text { Credit decision } \\
\text { spouse } \\
\beta / \mathrm{SE}\end{array}$ & $\begin{array}{c}(5) \\
\text { Investment decision } \\
\text { involved } \\
\beta / \mathrm{SE}\end{array}$ & $\begin{array}{c}(6) \\
\text { Investment decision } \\
\text { spouse } \\
\beta / \mathrm{SE}\end{array}$ & $\begin{array}{c}(7) \\
\text { Number decisions } \\
\text { involved in } \\
\beta / \mathrm{SE}\end{array}$ \\
\hline \multirow[t]{2}{*}{ Financial literacy index } & $0.059^{*}$ & -0.076 & 0.028 & $-0.055^{* *}$ & $0.063^{* *}$ & $-0.101^{* *}$ & $0.166^{* *}$ \\
\hline & $(0.033)$ & (0.050) & $(0.018)$ & $(0.028)$ & $(0.029)$ & $(0.046)$ & $(0.065)$ \\
\hline Age & $\begin{array}{r}0.012^{*} \\
(0.006)\end{array}$ & $\begin{array}{r}-0.003 \\
(0.009)\end{array}$ & $0.009^{* *}$ & -0.006 & $0.015^{* * *}$ & $-0.013^{*}$ & $0.032^{* *}$ \\
\hline \multirow{2}{*}{$\mathrm{Age}^{2}$} & $\begin{array}{l}(0.006) \\
-0.000\end{array}$ & $\begin{array}{l}(0.009) \\
-0.000\end{array}$ & $\begin{array}{c}(0.004) \\
-0.000^{* *}\end{array}$ & $\begin{array}{c}(0.005) \\
0.000\end{array}$ & $\begin{array}{c}(0.005) \\
-0.000^{* *}\end{array}$ & $\begin{array}{c}(0.007) \\
0.000\end{array}$ & $\begin{array}{c}(0.014) \\
-0.000^{*}\end{array}$ \\
\hline & $(0.000)$ & $(0.000)$ & $(0.000)$ & $(0.000)$ & $(0.000)$ & $(0.000)$ & $(0.000)$ \\
\hline \multirow[t]{2}{*}{ Spell } & 0.005 & -0.010 & -0.009 & 0.013 & -0.017 & 0.029 & -0.028 \\
\hline & $(0.030)$ & $(0.044)$ & $(0.017)$ & $(0.026)$ & $(0.025)$ & $(0.036)$ & $(0.059)$ \\
\hline \multirow[t]{2}{*}{ Married } & -0.013 & & -0.017 & & $-0.096^{* * *}$ & & -0.092 \\
\hline & $(0.046)$ & & $(0.023)$ & & $(0.033)$ & & $(0.078)$ \\
\hline \multirow[t]{2}{*}{ Widowed } & $0.097^{*}$ & & 0.009 & & $-0.058^{*}$ & & 0.119 \\
\hline & $(0.052)$ & & $(0.024)$ & & $(0.033)$ & & $(0.088)$ \\
\hline \multirow[t]{3}{*}{ Divorced } & $0.129^{* * *}$ & & -0.005 & & -0.052 & & 0.142 \\
\hline & $(0.048)$ & & $(0.029)$ & & $(0.034)$ & & $(0.093)$ \\
\hline & $-0.022^{* *}$ & 0.014 & -0.005 & -0.001 & $-0.015^{* *}$ & 0.007 & $-0.041^{* * *}$ \\
\hline & $(0.009)$ & $(0.014)$ & $(0.004)$ & $(0.005)$ & $(0.006)$ & $(0.008)$ & $(0.015)$ \\
\hline \multirow[t]{2}{*}{ Children (0-5 years) } & 0.024 & -0.014 & 0.010 & -0.011 & 0.018 & -0.018 & $0.048^{*}$ \\
\hline & $(0.018)$ & $(0.025)$ & $(0.009)$ & $(0.012)$ & $(0.013)$ & $(0.017)$ & $(0.029)$ \\
\hline \multirow[t]{2}{*}{ Children (6-12 years) } & 0.013 & -0.009 & -0.008 & 0.016 & $0.019^{*}$ & -0.016 & 0.027 \\
\hline & $(0.012)$ & $(0.017)$ & $(0.008)$ & $(0.010)$ & $(0.010)$ & $(0.014)$ & $(0.024)$ \\
\hline \multirow[t]{2}{*}{ Children (13-17 years) } & 0.011 & -0.009 & 0.002 & -0.001 & 0.008 & 0.002 & 0.024 \\
\hline & $(0.014)$ & $(0.019)$ & $(0.006)$ & $(0.007)$ & $(0.009)$ & $(0.011)$ & $(0.021)$ \\
\hline \multirow[t]{2}{*}{ Expenditure (Q2) } & 0.037 & -0.047 & 0.004 & 0.004 & 0.013 & -0.007 & 0.073 \\
\hline & $(0.025)$ & $(0.045)$ & $(0.016)$ & $(0.027)$ & $(0.021)$ & $(0.033)$ & $(0.051)$ \\
\hline \multirow[t]{2}{*}{ Expenditure (Q3) } & -0.004 & -0.014 & -0.014 & 0.022 & -0.017 & 0.042 & -0.008 \\
\hline & $(0.033)$ & $(0.053)$ & $(0.020)$ & $(0.030)$ & $(0.028)$ & $(0.043)$ & $(0.066)$ \\
\hline \multirow[t]{2}{*}{ Expenditure (Q4) } & 0.028 & -0.074 & 0.002 & 0.007 & -0.028 & 0.050 & 0.035 \\
\hline & $(0.032)$ & $(0.049)$ & $(0.019)$ & $(0.028)$ & $(0.027)$ & $(0.040)$ & $(0.061)$ \\
\hline \multirow[t]{2}{*}{ Asset index } & -0.008 & 0.007 & 0.000 & 0.005 & 0.003 & -0.001 & -0.008 \\
\hline & $(0.008)$ & $(0.010)$ & $(0.004)$ & $(0.005)$ & $(0.006)$ & $(0.007)$ & $(0.014)$ \\
\hline Observations & 1057 & 705 & 1057 & 705 & 1033 & 686 & 1057 \\
\hline & 0.046 & -0.016 & 0.015 & -0.035 & -0.002 & -0.083 & 0.026 \\
\hline Kleibergen-Paap F stat & 55.384 & 35.166 & 55.384 & 35.166 & 52.407 & 33.526 & 55.384 \\
\hline
\end{tabular}

Note: The table reports coefficients of IV regressions with standard errors clustered at VSLG level in brackets. * p $<0.10, * * \mathrm{p}<0.05, * * * \mathrm{p}<0.01$ denote statistical significance. The outcome variable in column 1, 3 and 5 is one if women are involved in the decision. The outcome variable in columns 2,4 and 6 is one if their husbands decide alone. Column 7 counts the number of financial decisions women are involved in. Financial literacy is an index which is generated by giving one point for each financial literacy question answered correctly. The instrument used is the average group index of financial literacy excluding the individual considered. 
Table 9: IV with FL Index (Household)

\begin{tabular}{|c|c|c|c|c|c|c|c|c|}
\hline & $\begin{array}{c}(1) \\
\text { Food } \\
\text { involved } \\
\beta / \mathrm{SE}\end{array}$ & $\begin{array}{c}(2) \\
\text { Food } \\
\text { spouse } \\
\beta / \mathrm{SE}\end{array}$ & $\begin{array}{c}(3) \\
\text { Own health } \\
\text { involved } \\
\beta / \mathrm{SE}\end{array}$ & $\begin{array}{c}(4) \\
\text { Own health } \\
\text { spouse } \\
\beta / \mathrm{SE}\end{array}$ & $\begin{array}{c}(5) \\
\text { Own clothes } \\
\text { involved } \\
\beta / \mathrm{SE}\end{array}$ & $\begin{array}{c}(6) \\
\text { Own clothes } \\
\text { spouse } \\
\beta / \mathrm{SE}\end{array}$ & $\begin{array}{c}(7) \\
\text { Energy } \\
\text { involved } \\
\beta / \mathrm{SE}\end{array}$ & $\begin{array}{c}(8) \\
\text { Energy } \\
\text { spouse } \\
\beta / \mathrm{SE}\end{array}$ \\
\hline Financial literacy index & $\begin{array}{l}0.029 \\
(0.026)\end{array}$ & $\begin{array}{l}-0.029 \\
(0.040)\end{array}$ & $0.058^{* *}$ & $-0.084 * *$ & $0.074^{* *}$ & $-0.090^{*}$ & $\begin{array}{l}0.069 \\
(0.043)\end{array}$ & -0.096 \\
\hline Age & $0.018^{* * *}$ & -0.010 & $0.012^{* *}$ & -0.005 & $0.008^{*}$ & $-0.013^{*}$ & $0.022^{* * *}$ & $-0.021^{* *}$ \\
\hline \multirow[b]{2}{*}{$\mathrm{Age}^{2}$} & $(0.005)$ & $(0.007)$ & $(0.005)$ & $(0.007)$ & $(0.004)$ & $(0.007)$ & $(0.006)$ & $(0.010)$ \\
\hline & $-0.000^{* * *}$ & 0.000 & $-0.000^{*}$ & 0.000 & -0.000 & 0.000 & $-0.000^{* * *}$ & $0.000^{*}$ \\
\hline & $(0.000)$ & $(0.000)$ & $(0.000)$ & $(0.000)$ & $(0.000)$ & $(0.000)$ & $(0.000)$ & $(0.000)$ \\
\hline \multirow[t]{2}{*}{ Spell } & 0.009 & -0.027 & -0.033 & 0.041 & -0.029 & 0.021 & 0.013 & -0.022 \\
\hline & $(0.023)$ & $(0.033)$ & $(0.025)$ & $(0.036)$ & $(0.025)$ & $(0.036)$ & $(0.035)$ & $(0.052)$ \\
\hline \multirow[t]{2}{*}{ Married } & $0.103^{*}$ & & -0.010 & & $-0.065^{*}$ & & 0.033 & \\
\hline & $(0.053)$ & & $(0.043)$ & & $(0.038)$ & & $(0.057)$ & \\
\hline \multirow[t]{2}{*}{ Widowed } & $0.136^{* *}$ & & 0.039 & & -0.022 & & $0.156^{* *}$ & \\
\hline & $(0.053)$ & & $(0.044)$ & & $(0.042)$ & & $(0.065)$ & \\
\hline \multirow[t]{2}{*}{ Divorced } & $0.134^{* *}$ & & 0.051 & & -0.016 & & $0.166^{* * *}$ & \\
\hline & $(0.053)$ & & $(0.042)$ & & $(0.041)$ & & $(0.059)$ & \\
\hline \multirow[t]{2}{*}{ HH size } & $-0.020^{* * *}$ & -0.003 & -0.008 & -0.001 & -0.002 & 0.005 & $-0.023^{* *}$ & -0.009 \\
\hline & $(0.007)$ & $(0.008)$ & $(0.007)$ & $(0.008)$ & $(0.006)$ & $(0.009)$ & $(0.009)$ & $(0.012)$ \\
\hline \multirow[t]{2}{*}{ Children (0-5 years) } & 0.015 & 0.005 & 0.004 & -0.000 & 0.010 & $-0.029^{*}$ & 0.020 & 0.018 \\
\hline & $(0.012)$ & $(0.017)$ & $(0.013)$ & $(0.018)$ & $(0.011)$ & $(0.016)$ & $(0.017)$ & $(0.023)$ \\
\hline \multirow[t]{2}{*}{ Children (6-12 years) } & 0.013 & 0.005 & 0.005 & 0.002 & 0.004 & -0.002 & 0.018 & 0.008 \\
\hline & $(0.010)$ & $(0.012)$ & $(0.009)$ & $(0.012)$ & $(0.010)$ & $(0.014)$ & $(0.012)$ & $(0.016)$ \\
\hline \multirow{2}{*}{ Children (13-17 years) } & 0.010 & 0.001 & -0.000 & 0.001 & $0.014^{*}$ & $-0.023^{*}$ & 0.001 & 0.032 \\
\hline & $(0.009)$ & $(0.010)$ & $(0.010)$ & $(0.013)$ & $(0.008)$ & $(0.012)$ & $(0.015)$ & $(0.022)$ \\
\hline \multirow[t]{2}{*}{ Expenditure (Q2) } & 0.016 & -0.027 & 0.029 & -0.034 & 0.012 & -0.030 & -0.001 & -0.003 \\
\hline & $(0.021)$ & $(0.033)$ & $(0.020)$ & $(0.033)$ & $(0.018)$ & $(0.028)$ & $(0.029)$ & $(0.050)$ \\
\hline \multirow[t]{2}{*}{ Expenditure (Q3) } & 0.013 & -0.026 & 0.005 & -0.001 & -0.035 & 0.022 & -0.022 & 0.034 \\
\hline & $(0.024)$ & $(0.036)$ & $(0.024)$ & $(0.039)$ & $(0.024)$ & $(0.037)$ & $(0.031)$ & $(0.051)$ \\
\hline \multirow[t]{2}{*}{ Expenditure (Q4) } & 0.007 & -0.009 & 0.008 & 0.002 & -0.007 & 0.007 & -0.004 & -0.012 \\
\hline & $(0.024)$ & $(0.034)$ & $(0.024)$ & $(0.035)$ & $(0.021)$ & $(0.032)$ & $(0.033)$ & $(0.050)$ \\
\hline \multirow[t]{2}{*}{ Asset index } & -0.001 & 0.001 & 0.004 & -0.004 & -0.009 & 0.010 & $-0.015^{*}$ & $0.024^{* *}$ \\
\hline & $(0.006)$ & $(0.007)$ & $(0.005)$ & $(0.007)$ & $(0.006)$ & $(0.008)$ & $(0.009)$ & $(0.011)$ \\
\hline Observations & 1056 & 704 & 1057 & 705 & 1057 & 705 & 1055 & 704 \\
\hline$R^{2}$ & 0.077 & 0.023 & 0.000 & -0.068 & -0.047 & -0.043 & 0.046 & -0.026 \\
\hline Kleibergen-Paap F stat & 67.114 & 38.112 & 66.963 & 37.940 & 66.963 & 37.940 & 68.181 & 38.071 \\
\hline
\end{tabular}

Note: The table reports coefficients of multivariate regressions with standard errors clustered at VSLG level in brackets. ${ }^{*} \mathrm{p}<0.10, * * \mathrm{p}<0.05, * * * \mathrm{p}<0.01$ denote statistical significance. Financial literacy is an index which is generated by giving one point for each financial literacy question answered correctly. 
Table 10: IV with FL Index (Children)

\begin{tabular}{|c|c|c|c|c|c|}
\hline & $\begin{array}{c}(1) \\
\text { Children health } \\
\text { involved } \\
\beta / \mathrm{SE}\end{array}$ & $\begin{array}{c}(2) \\
\text { Children health } \\
\text { spouse } \\
\beta / \mathrm{SE}\end{array}$ & $\begin{array}{c}(3) \\
\text { Children clothes } \\
\text { involved } \\
\beta / \mathrm{SE}\end{array}$ & $\begin{array}{c}(4) \\
\text { Children clothes } \\
\text { spouse } \\
\beta / \mathrm{SE}\end{array}$ & $\begin{array}{c}(5) \\
\text { Number decisions } \\
\text { involved in } \\
\beta / \mathrm{SE}\end{array}$ \\
\hline Financial literacy index & $\begin{array}{l}0.045^{*} \\
(0.026)\end{array}$ & $\begin{array}{r}-0.045 \\
(0.033)\end{array}$ & $\begin{array}{c}0.052^{* *} \\
(0.025)\end{array}$ & $\begin{array}{r}-0.062^{*} \\
(0.033)\end{array}$ & $\begin{array}{c}0.342^{* *} \\
(0.139)\end{array}$ \\
\hline \multirow[t]{2}{*}{ Age } & 0.011 & 0.003 & 0.009 & 0.001 & $0.101^{* * *}$ \\
\hline & $(0.007)$ & $(0.006)$ & $(0.007)$ & $(0.006)$ & $(0.022)$ \\
\hline \multirow[t]{2}{*}{$\mathrm{Age}^{2}$} & -0.000 & -0.000 & -0.000 & -0.000 & $-0.001^{* * *}$ \\
\hline & $(0.000)$ & $(0.000)$ & $(0.000)$ & $(0.000)$ & $(0.000)$ \\
\hline \multirow[t]{2}{*}{ Spell } & -0.011 & -0.004 & -0.015 & 0.010 & -0.031 \\
\hline & $(0.024)$ & $(0.030)$ & $(0.023)$ & $(0.028)$ & $(0.119)$ \\
\hline \multirow[t]{2}{*}{ Married } & 0.025 & & -0.003 & & $0.361^{*}$ \\
\hline & $(0.050)$ & & $(0.044)$ & & $(0.209)$ \\
\hline \multirow[t]{2}{*}{ Widowed } & 0.059 & & 0.036 & & $0.538^{* *}$ \\
\hline & $(0.052)$ & & $(0.047)$ & & $(0.234)$ \\
\hline \multirow[t]{2}{*}{ Divorced } & 0.057 & & 0.012 & & $0.593^{* *}$ \\
\hline & $(0.052)$ & & $(0.049)$ & & $(0.242)$ \\
\hline \multirow{2}{*}{ HH size } & -0.012 & 0.007 & -0.007 & 0.004 & $-0.126^{* * *}$ \\
\hline & $(0.007)$ & $(0.008)$ & $(0.007)$ & $(0.007)$ & $(0.034)$ \\
\hline \multirow[t]{2}{*}{ Children (0-5 years) } & 0.010 & -0.004 & 0.005 & -0.007 & $0.429^{* * *}$ \\
\hline & $(0.011)$ & $(0.014)$ & $(0.010)$ & $(0.012)$ & $(0.054)$ \\
\hline \multirow[t]{2}{*}{ Children (6-12 years) } & 0.002 & -0.002 & 0.003 & -0.001 & $0.309^{* * *}$ \\
\hline & $(0.008)$ & $(0.010)$ & $(0.009)$ & $(0.010)$ & $(0.042)$ \\
\hline \multirow[t]{2}{*}{ Children (13-17 years) } & -0.002 & -0.006 & 0.002 & -0.010 & $0.295^{* * *}$ \\
\hline & $(0.008)$ & $(0.009)$ & $(0.007)$ & $(0.009)$ & $(0.042)$ \\
\hline \multirow[t]{2}{*}{ Expenditure (Q2) } & 0.008 & -0.013 & -0.020 & 0.032 & 0.043 \\
\hline & $(0.021)$ & $(0.032)$ & $(0.021)$ & $(0.031)$ & $(0.101)$ \\
\hline \multirow[t]{2}{*}{ Expenditure (Q3) } & -0.011 & -0.001 & -0.035 & 0.029 & -0.012 \\
\hline & $(0.025)$ & $(0.035)$ & $(0.023)$ & $(0.032)$ & $(0.116)$ \\
\hline \multirow[t]{2}{*}{ Expenditure (Q4) } & 0.021 & -0.028 & 0.009 & -0.002 & 0.083 \\
\hline & $(0.022)$ & $(0.032)$ & $(0.020)$ & $(0.029)$ & $(0.113)$ \\
\hline \multirow[t]{2}{*}{ Asset index } & -0.003 & 0.002 & 0.000 & 0.001 & -0.033 \\
\hline & $(0.005)$ & $(0.006)$ & $(0.005)$ & $(0.006)$ & $(0.026)$ \\
\hline Observations & 863 & 634 & 862 & 634 & 1057 \\
\hline & -0.026 & -0.034 & -0.050 & -0.081 & 0.165 \\
\hline Kleibergen-Paap F stat & 54.463 & 35.682 & 54.754 & 35.682 & 66.963 \\
\hline
\end{tabular}


Table 11: Regression results for financial literacy index

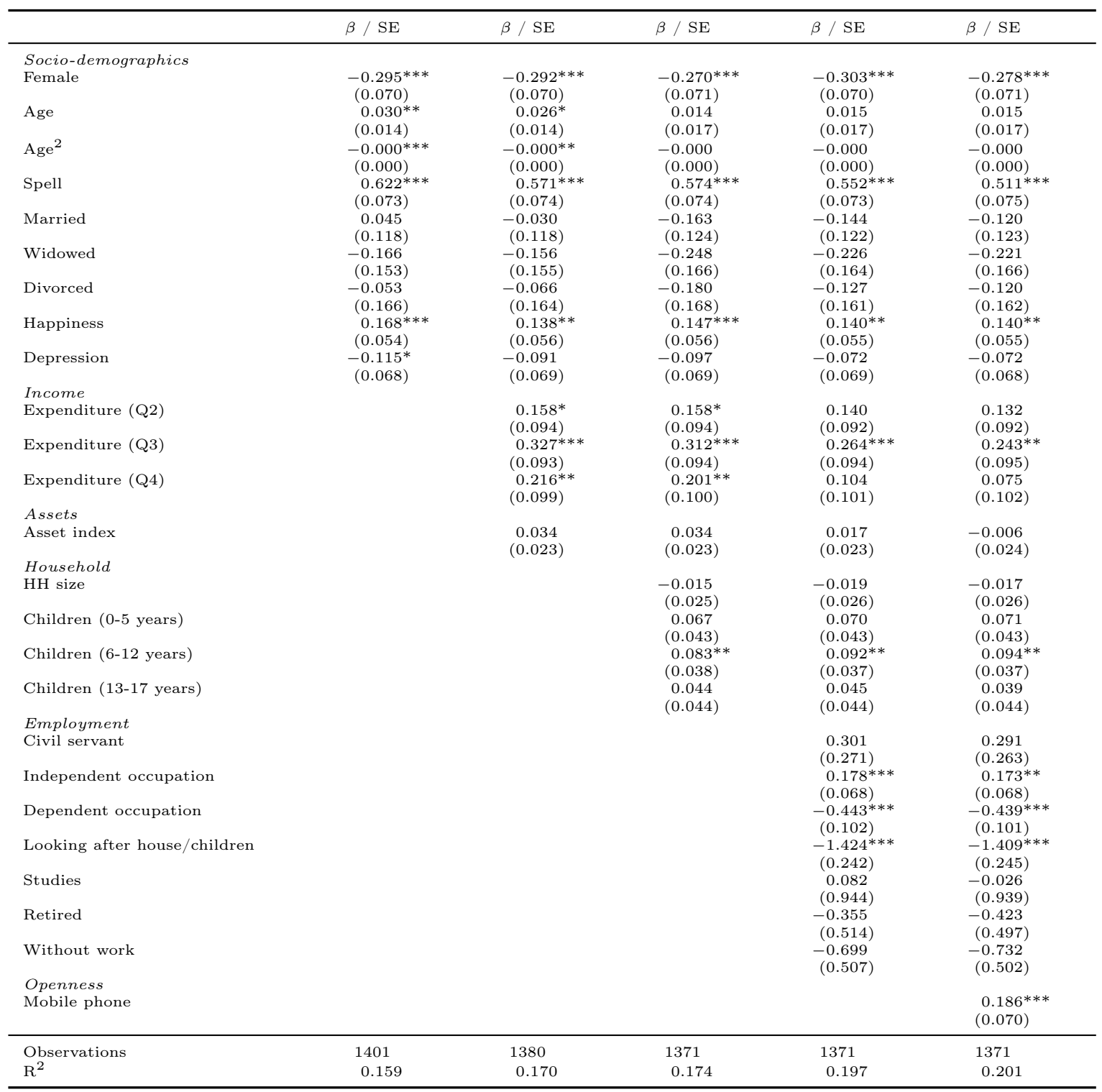

Note: The table reports coefficients of multivariate regression results with standard errors clustered at VSLG level in brackets. The outcome variable is the financial literacy index which is generated by giving one point for each financial literacy question answered correctly. Happiness and Depression are scores on a scale designed to measure mental well-being. ${ }^{*} \mathrm{p}<0.10,{ }^{*} \mathrm{p}<0.05, * * * \mathrm{p}<0.01$ denote statistical significance. 
Table 12: Decomposition of financial literacy index

\begin{tabular}{|c|c|c|c|c|c|}
\hline & withou & ssets & & with & ets \\
\hline & Coefficient & Share & & Coefficient & Share \\
\hline Overall & & & & & \\
\hline Male & $2.833^{* * *}$ & & Male & $2.833^{* * *}$ & \\
\hline Female & $2.363^{* * *}$ & & Female & $2.363^{* * *}$ & \\
\hline Difference & $0.470^{* * *}$ & 100.000 & Difference & $0.470^{* * *}$ & 100.000 \\
\hline Endowment Eff. & $0.223^{* * *}$ & 47.331 & Endowment Eff. & $0.223^{* * *}$ & 47.403 \\
\hline Coefficient Eff. & $0.248^{* * *}$ & 52.669 & Coefficient Eff. & $0.247^{* * *}$ & 52.597 \\
\hline Endowment Eff & & & & & \\
\hline Age & -0.053 & -11.208 & Age & -0.050 & -10.685 \\
\hline $\mathrm{Age}^{2}$ & 0.064 & 13.612 & $\mathrm{Age}^{2}$ & 0.063 & 13.290 \\
\hline Single & 0.008 & 1.614 & Single & 0.008 & 1.701 \\
\hline Married & 0.006 & 1.286 & Married & 0.005 & 1.054 \\
\hline Divorced & 0.001 & 0.156 & Divorced & 0.001 & 0.129 \\
\hline Widowed & 0.019 & 4.017 & Widowed & 0.018 & 3.878 \\
\hline Spell & $0.084^{* * *}$ & 17.878 & Spell & $0.084^{* * *}$ & 17.771 \\
\hline Children (6-12) & -0.001 & -0.247 & Children (6-12) & -0.001 & -0.245 \\
\hline Happy & $0.023^{*}$ & 4.961 & Happy & $0.023^{*}$ & 4.825 \\
\hline Depression & 0.013 & 2.720 & Depression & 0.013 & 2.659 \\
\hline Mobile phone & $0.059^{* *}$ & 12.542 & Mobile phone & $0.053^{* *}$ & 11.280 \\
\hline & & & Asset index & 0.008 & 1.747 \\
\hline Coefficient Eff. & & & & & \\
\hline Age & 1.313 & 279.224 & Age & 0.912 & 193.894 \\
\hline $\mathrm{Age}^{2}$ & -0.614 & -130.616 & $\mathrm{Age}^{2}$ & -0.461 & -98.103 \\
\hline Single & -0.029 & -6.229 & Single & -0.026 & -5.565 \\
\hline Married & -0.033 & -7.027 & Married & -0.052 & -11.065 \\
\hline Divorced & 0.016 & 3.457 & Divorced & 0.018 & 3.844 \\
\hline Widowed & -0.005 & -1.011 & Widowed & -0.005 & -1.045 \\
\hline Spell & 0.048 & 10.231 & Spell & 0.008 & 1.650 \\
\hline Children (6-12) & 0.034 & 7.276 & Children (6-12) & 0.029 & 6.201 \\
\hline Happy & -0.460 & -97.848 & Happy & -0.566 & -120.427 \\
\hline Depression & -0.032 & -6.757 & Depression & -0.024 & -5.024 \\
\hline Mobile phone & 0.035 & 7.513 & Mobile phone & -0.084 & -17.827 \\
\hline & & & Asset index & $0.034^{*}$ & 7.203 \\
\hline Constant & -0.026 & -5.542 & Constant & 0.465 & 98.862 \\
\hline
\end{tabular}

Note: ${ }^{*} \mathrm{p}<0.10,{ }^{* *} \mathrm{p}<0.05,{ }^{* * *} \mathrm{p}<0.01$ denote statistical significance. 


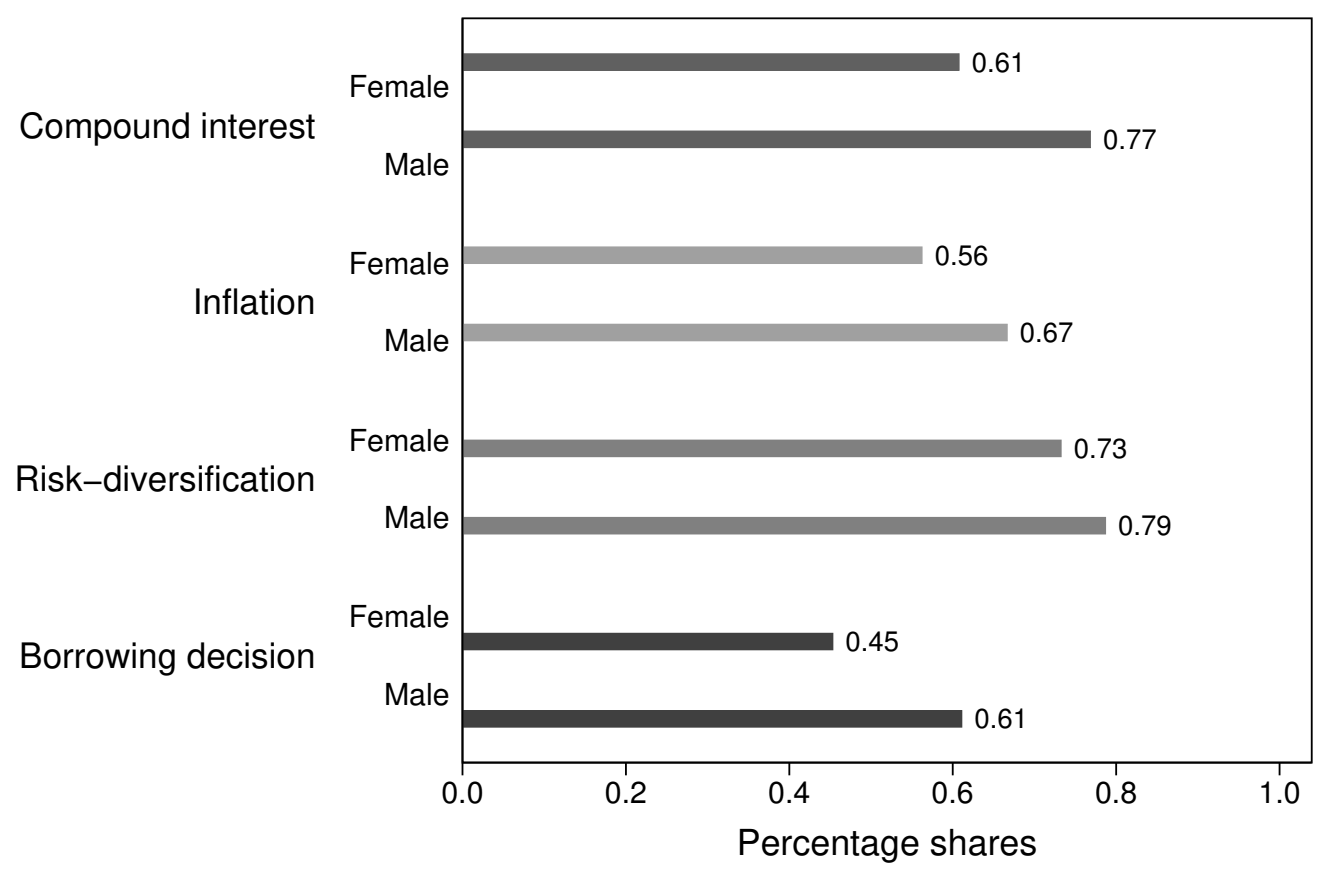

Figure 1: Gender differences in financial literacy 


\section{B. Additional tables and figures}

Table B.1: Distribution of financial literacy responses by socio-demographics

\begin{tabular}{|c|c|c|c|c|c|c|c|c|}
\hline & \multicolumn{2}{|c|}{ Compound interest } & \multicolumn{2}{|c|}{ Inflation } & \multicolumn{2}{|c|}{ Risk-diversification } & \multicolumn{2}{|c|}{ Borrowing } \\
\hline & Correct & DK & Correct & DK & Correct & DK & Correct & DK \\
\hline \multicolumn{9}{|l|}{ Age } \\
\hline$<35$ & 72.61 & 15.43 & 63.48 & 11.96 & 74.57 & 1.09 & 56.96 & 10.65 \\
\hline $35-54$ & 67.03 & 20.66 & 62.46 & 16.56 & 73.82 & 1.10 & 50.16 & 17.19 \\
\hline $55-64$ & 53.88 & 34.25 & 43.84 & 34.25 & 77.17 & 0.91 & 38.36 & 29.68 \\
\hline $65+$ & 31.52 & 54.35 & 43.48 & 44.57 & 72.83 & 4.35 & 26.09 & 51.09 \\
\hline \multicolumn{9}{|l|}{ Gender } \\
\hline Female & 60.78 & 25.90 & 56.24 & 22.48 & 73.27 & 1.30 & 45.33 & 21.74 \\
\hline Male & 76.85 & 14.51 & 66.67 & 10.19 & 78.70 & 1.23 & 61.11 & 10.80 \\
\hline \multicolumn{9}{|l|}{ Education } \\
\hline Primary and less & 63.69 & 23.89 & 59.18 & 19.47 & 75.34 & 1.11 & 48.38 & 19.56 \\
\hline Secondary and more & 87.50 & 1.92 & 78.85 & 2.88 & 83.65 & 0.96 & 58.65 & 6.73 \\
\hline Other & 60.61 & 33.33 & 48.48 & 21.21 & 75.76 & 0.00 & 54.55 & 12.12 \\
\hline \multicolumn{9}{|l|}{ Marital status } \\
\hline Single & 75.20 & 14.40 & 53.60 & 12.00 & 76.00 & 1.60 & 64.80 & 8.80 \\
\hline Widowed & 46.64 & 40.81 & 43.50 & 35.43 & 70.85 & 1.79 & 30.94 & 38.57 \\
\hline Divorced & 57.14 & 29.19 & 48.81 & 26.19 & 63.10 & 1.19 & 55.95 & 20.24 \\
\hline Married & 67.73 & 20.21 & 63.71 & 16.49 & 76.08 & 1.13 & 50.52 & 15.98 \\
\hline \multicolumn{9}{|l|}{ Employment } \\
\hline Farmer (indep.) & 63.40 & 23.73 & 57.54 & 20.46 & 73.49 & 1.34 & 47.74 & 19.98 \\
\hline $\begin{array}{l}\text { Independent } \\
\text { occupation }\end{array}$ & 73.51 & 16.79 & 67.16 & 12.69 & 79.85 & 0.75 & 54.58 & 13.81 \\
\hline $\begin{array}{l}\text { Dependent } \\
\text { occupation }\end{array}$ & 46.88 & 39.06 & 37.50 & 31.25 & 70.31 & 1.56 & 46.88 & 28.13 \\
\hline $\begin{array}{l}\text { Without } \\
\text { occupation }\end{array}$ & 28.57 & 71.43 & 14.29 & 85.71 & 71.43 & 14.29 & 28.57 & 71.43 \\
\hline
\end{tabular}

Note: The acronym DK stands for "Don't know". 
Table B.2: Probit with FL Index

\begin{tabular}{|c|c|c|c|c|c|c|}
\hline & $\begin{array}{c}(1) \\
\text { Income decision } \\
\text { involved } \\
\text { Mfx / SE }\end{array}$ & $\begin{array}{c}(2) \\
\text { Income decision } \\
\text { spouse } \\
\text { Mfx / SE }\end{array}$ & $\begin{array}{c}(3) \\
\text { Credit decision } \\
\text { involved } \\
\text { Mfx / SE }\end{array}$ & $\begin{array}{c}(4) \\
\text { Credit decision } \\
\text { spouse } \\
\text { Mfx / SE }\end{array}$ & $\begin{array}{c}(5) \\
\text { Investment decision } \\
\text { involved } \\
\text { Mfx / SE }\end{array}$ & $\begin{array}{c}(6) \\
\text { Investment decision } \\
\text { spouse } \\
\text { Mfx / SE }\end{array}$ \\
\hline Financial literacy index & $\begin{array}{l}0.017^{* *} \\
(0.043)\end{array}$ & $\begin{array}{c}-0.014 \\
(0.048)\end{array}$ & $\begin{array}{l}0.008^{* * *} \\
(0.063)\end{array}$ & $\begin{array}{c}-0.013^{* *} \\
(0.068)\end{array}$ & $\begin{array}{l}0.015^{* * *} \\
(0.054)\end{array}$ & $\begin{array}{c}-0.021 * * * \\
(0.060)\end{array}$ \\
\hline \multirow[t]{2}{*}{ Age } & 0.010 & -0.001 & $0.006^{* * *}$ & -0.005 & $0.012^{* * *}$ & -0.008 \\
\hline & $(0.038)$ & $(0.042)$ & $(0.042)$ & $(0.050)$ & $(0.034)$ & $(0.046)$ \\
\hline \multirow[t]{2}{*}{$\mathrm{Age}^{2}$} & -0.000 & -0.000 & $-0.000^{* * *}$ & 0.000 & $-0.000^{* * *}$ & 0.000 \\
\hline & $(0.000)$ & $(0.000)$ & $(0.000)$ & $(0.001)$ & $(0.000)$ & $(0.000)$ \\
\hline Spell & 0.023 & $\begin{array}{l}-0.043 \\
(0.132)\end{array}$ & $\begin{array}{l}0.001 \\
(0209)\end{array}$ & $\begin{array}{l}-0.010 \\
(0.227)\end{array}$ & 0.008 & -0.016 \\
\hline \multirow{2}{*}{ Married } & $\begin{array}{c}(0.125) \\
-0.030\end{array}$ & $(0.132)$ & $\begin{array}{c}(0.209) \\
-0.018\end{array}$ & $(0.227)$ & $\begin{array}{l}(0.145) \\
-0.106^{* * *}\end{array}$ & $(0.186)$ \\
\hline & $(0.205)$ & & $(0.312)$ & & $(0.338)$ & \\
\hline \multirow[t]{2}{*}{ Widowed } & $0.138^{* *}$ & & 0.028 & & $-0.066^{*}$ & \\
\hline & $(0.347)$ & & $(0.441)$ & & $(0.394)$ & \\
\hline \multirow[t]{2}{*}{ Divorced } & $0.173^{* *}$ & & -0.011 & & $-0.074^{*}$ & \\
\hline & $(0.434)$ & & $(0.422)$ & & $(0.418)$ & \\
\hline \multirow[t]{2}{*}{ HH size } & $-0.019^{* * *}$ & 0.014 & -0.004 & -0.001 & $-0.014^{* * *}$ & 0.005 \\
\hline & $(0.042)$ & $(0.054)$ & $(0.053)$ & $(0.062)$ & $(0.042)$ & $(0.059)$ \\
\hline \multirow[t]{2}{*}{ Children (0-5 years) } & 0.020 & -0.019 & 0.007 & -0.012 & 0.017 & -0.019 \\
\hline & $(0.084)$ & $(0.097)$ & $(0.122)$ & $(0.146)$ & $(0.104)$ & $(0.117)$ \\
\hline \multirow[t]{2}{*}{ Children (6-12 years) } & 0.012 & -0.013 & -0.005 & 0.012 & $0.018^{* *}$ & -0.018 \\
\hline & $(0.061)$ & $(0.068)$ & $(0.092)$ & $(0.098)$ & $(0.075)$ & $(0.096)$ \\
\hline \multirow[t]{2}{*}{ Children (13-17 years) } & 0.009 & -0.011 & 0.001 & -0.001 & 0.009 & 0.001 \\
\hline & $(0.071)$ & $(0.078)$ & $(0.086)$ & $(0.092)$ & $(0.077)$ & $(0.081)$ \\
\hline \multirow[t]{2}{*}{ Expenditure (Q2) } & 0.038 & -0.058 & 0.003 & -0.006 & 0.013 & -0.029 \\
\hline & $(0.145)$ & $(0.166)$ & $(0.239)$ & $(0.281)$ & $(0.192)$ & $(0.248)$ \\
\hline \multirow[t]{2}{*}{ Expenditure (Q3) } & 0.003 & -0.036 & -0.006 & 0.000 & -0.006 & 0.009 \\
\hline & $(0.160)$ & $(0.172)$ & $(0.248)$ & $(0.277)$ & $(0.194)$ & $(0.240)$ \\
\hline \multirow[t]{2}{*}{ Expenditure (Q4) } & 0.030 & $-0.096^{* *}$ & 0.003 & -0.011 & -0.017 & 0.020 \\
\hline & $(0.155)$ & $(0.174)$ & $(0.260)$ & $(0.281)$ & $(0.197)$ & $(0.231)$ \\
\hline \multirow[t]{2}{*}{ Asset index } & -0.005 & 0.007 & 0.000 & 0.005 & 0.004 & -0.001 \\
\hline & $(0.039)$ & $(0.039)$ & $(0.055)$ & $(0.057)$ & $(0.045)$ & $(0.049)$ \\
\hline Observations & 1057 & 705 & 1057 & 705 & 1033 & 686 \\
\hline Pseudo $R^{2}$ & 0.107 & 0.023 & 0.095 & 0.050 & 0.089 & 0.074 \\
\hline
\end{tabular}


Table B.3: OLS with FL Index only for married women

\begin{tabular}{|c|c|c|c|c|}
\hline & $\begin{array}{c}(1) \\
\text { Income decision } \\
\text { involved } \\
\beta / \mathrm{SE}\end{array}$ & $\begin{array}{c}(2) \\
\text { Credit decision } \\
\text { involved } \\
\beta / \mathrm{SE}\end{array}$ & $\begin{array}{c}(3) \\
\text { Investment decision } \\
\text { involved } \\
\beta / \mathrm{SE}\end{array}$ & $\begin{array}{c}(4) \\
\text { Number decisions } \\
\text { involved in } \\
\beta / \mathrm{SE}\end{array}$ \\
\hline Financial literacy index & $\begin{array}{c}0.016 \\
(0.012)\end{array}$ & $\begin{array}{c}0.014^{* *} \\
(0.007)\end{array}$ & $\begin{array}{l}0.021^{* *} \\
(0.009)\end{array}$ & $\begin{array}{c}0.055^{* *} \\
(0.023)\end{array}$ \\
\hline \multirow[t]{2}{*}{ Age } & 0.001 & 0.005 & $0.013^{*}$ & 0.012 \\
\hline & $(0.010)$ & $(0.005)$ & $(0.007)$ & $(0.017)$ \\
\hline \multirow[t]{2}{*}{$\mathrm{Age}^{2}$} & 0.000 & -0.000 & -0.000 & -0.000 \\
\hline & $(0.000)$ & $(0.000)$ & $(0.000)$ & $(0.000)$ \\
\hline Spell & $\begin{array}{c}0.042 \\
(0.035)\end{array}$ & $\begin{array}{c}0.010 \\
(0.022)\end{array}$ & $\begin{array}{c}0.029 \\
(0.025)\end{array}$ & $\begin{array}{c}0.078 \\
(0.068)\end{array}$ \\
\hline \multirow[b]{3}{*}{ Children $(0-5$ years $)$} & -0.014 & 0.001 & $-0.016^{*}$ & $\begin{array}{l}(0.068) \\
-0.021\end{array}$ \\
\hline & $(0.013)$ & $(0.005)$ & $(0.009)$ & $(0.020)$ \\
\hline & 0.020 & 0.014 & $0.038^{*}$ & $0.070^{*}$ \\
\hline & $(0.024)$ & $(0.012)$ & $(0.019)$ & $(0.040)$ \\
\hline \multirow[t]{2}{*}{ Children (6-12 years) } & 0.013 & -0.013 & $0.028^{* *}$ & 0.030 \\
\hline & $(0.016)$ & $(0.010)$ & $(0.013)$ & $(0.031)$ \\
\hline \multirow[t]{2}{*}{ Children (13-17 years) } & 0.011 & 0.003 & 0.014 & 0.028 \\
\hline & $(0.018)$ & $(0.007)$ & $(0.012)$ & $(0.027)$ \\
\hline \multirow[t]{2}{*}{ Expenditure (Q2) } & 0.065 & 0.008 & 0.045 & $0.151^{*}$ \\
\hline & $(0.043)$ & $(0.026)$ & $(0.033)$ & $(0.085)$ \\
\hline \multirow[t]{2}{*}{ Expenditure (Q3) } & 0.044 & -0.002 & 0.018 & 0.107 \\
\hline & $(0.047)$ & $(0.027)$ & $(0.035)$ & $(0.090)$ \\
\hline \multirow[t]{2}{*}{ Expenditure (Q4) } & $0.096 * *$ & 0.011 & -0.004 & $0.160^{*}$ \\
\hline & $(0.044)$ & $(0.026)$ & $(0.035)$ & $(0.082)$ \\
\hline \multirow[t]{2}{*}{ Asset index } & -0.007 & -0.005 & 0.001 & -0.013 \\
\hline & $(0.009)$ & $(0.005)$ & $(0.007)$ & $(0.016)$ \\
\hline \multirow{2}{*}{$\begin{array}{l}\text { Observations } \\
R^{2}\end{array}$} & 705 & 705 & 686 & 705 \\
\hline & 0.019 & 0.017 & 0.043 & 0.036 \\
\hline
\end{tabular}

Note: The table reports coefficients of multivariate regressions with standard errors clustered at VSLG level in brackets. $* \mathrm{p}<0.10, * * \mathrm{p}<0.05, * * * \mathrm{p}<0.01$ denote statistical significance. The outcome variable in column 1,2 and 3 is one if women are involved in the decision. Column 4 counts the number of financial decisions women are involved in. Financial literacy is an index which is generated by giving one point for each financial literacy question answered correctly. 
Table B.4: OLS with FL Index only married women (Household)

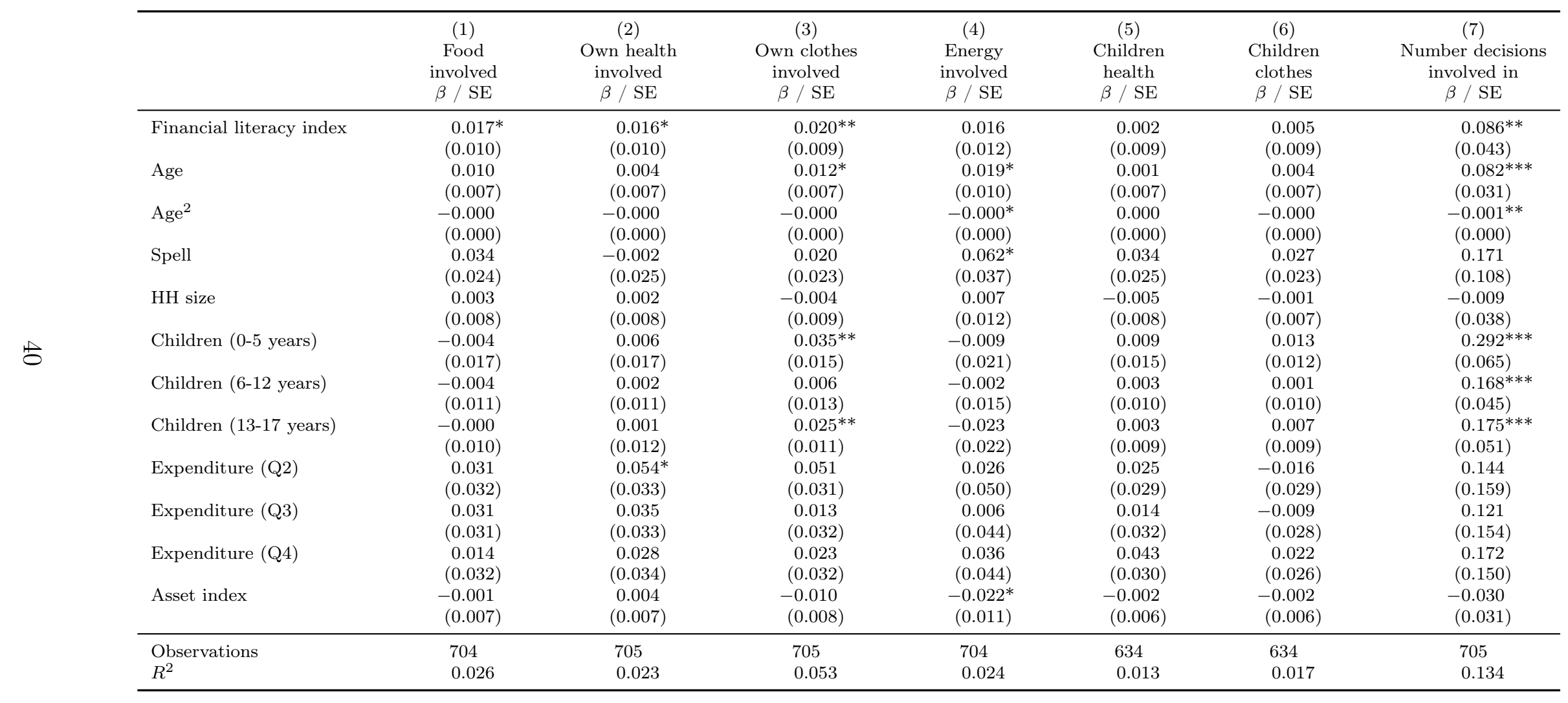

Note: The table reports coefficients of multivariate regressions with standard errors clustered at VSLG level in brackets. $* \mathrm{p}<0.10, * * \mathrm{p}<0.05, * * * \mathrm{p}<0.01$ denote statistical significance. Financial literacy is an index which is generated by giving one point for each financial literacy question answered correctly. 
Table B.5: First stage results for IV regression

\begin{tabular}{|c|c|}
\hline & Financial literacy Index \\
\hline Average group index of financial literacy & $\begin{array}{c}0.384 \\
(0.052)\end{array}$ \\
\hline Age & $\begin{array}{c}0.003 \\
(0.020)\end{array}$ \\
\hline $\mathrm{Age}^{2}$ & $\begin{array}{c}-0.000 \\
(0.000)\end{array}$ \\
\hline Spell & $\begin{array}{l}0.583^{* * *} \\
(0.081)\end{array}$ \\
\hline Married & $\begin{array}{c}-0.169 \\
(0.157)\end{array}$ \\
\hline Widowed & $\begin{array}{c}-0.279 \\
(0.196)\end{array}$ \\
\hline Divorced & $\begin{array}{c}-0.276 \\
(0.194)\end{array}$ \\
\hline HH size & $\begin{array}{c}0.013 \\
(0.029)\end{array}$ \\
\hline Children (0-5) & $\begin{array}{c}0.045 \\
(0.052)\end{array}$ \\
\hline Children (6-12) & $\begin{array}{c}0.050 \\
(0.042)\end{array}$ \\
\hline Children (13-17) & $\begin{array}{c}0.021 \\
(0.050)\end{array}$ \\
\hline Expenditure (Q2) & $\begin{array}{c}0.120 \\
(0.097)\end{array}$ \\
\hline Expenditure (Q3) & $\begin{array}{l}0.287^{* * *} \\
(0.098)\end{array}$ \\
\hline Expenditure (Q4) & $\begin{array}{c}0.217^{* *} \\
(0.105)\end{array}$ \\
\hline Asset index & $\begin{array}{c}0.021 \\
(0.025)\end{array}$ \\
\hline $\begin{array}{l}\text { Observations } \\
\text { F-Test }\end{array}$ & $\begin{array}{l}1057 \\
21.01\end{array}$ \\
\hline
\end{tabular}

Note: The table reports regression results for the first stage of the IV regression. ${ }^{*} \mathrm{p}<0.10,{ }^{* *} \mathrm{p}<0.05,{ }^{* * *} \mathrm{p}$ $<0.01$ denote statistical significance. The outcome variable is the financial literacy index which is generated by giving one point for each financial literacy question answered correctly. The average financial literacy level of the group excludes the individual considered. 
Table B.6: IV with FL Index only for married women

\begin{tabular}{|c|c|c|c|c|c|}
\hline & & $\begin{array}{c}(1) \\
\text { Income decision } \\
\text { involved } \\
\beta / \mathrm{SE}\end{array}$ & $\begin{array}{c}(2) \\
\text { Credit decision } \\
\text { involved } \\
\beta / \mathrm{SE}\end{array}$ & $\begin{array}{c}(3) \\
\text { Investment decision } \\
\text { involved } \\
\beta / \mathrm{SE}\end{array}$ & $\begin{array}{c}(4) \\
\text { Number decisions } \\
\text { involved in } \\
\beta / \mathrm{SE}\end{array}$ \\
\hline & Financial literacy index & $\begin{array}{c}0.075 \\
(0.050)\end{array}$ & $\begin{array}{c}0.055^{* *} \\
(0.028)\end{array}$ & $\begin{array}{c}0.078^{*} \\
(0.046)\end{array}$ & $\begin{array}{l}0.204^{* *} \\
(0.097)\end{array}$ \\
\hline & Age & $\begin{array}{c}0.002 \\
(0.009)\end{array}$ & $\begin{array}{c}0.006 \\
(0.005)\end{array}$ & $\begin{array}{l}0.013^{* *} \\
(0.007)\end{array}$ & $\begin{array}{c}0.014 \\
(0.017)\end{array}$ \\
\hline & $\mathrm{Age}^{2}$ & 0.000 & -0.000 & -0.000 & -0.000 \\
\hline & & $(0.000)$ & $(0.000)$ & $(0.000)$ & $(0.000)$ \\
\hline & Spell & 0.007 & -0.013 & -0.006 & -0.008 \\
\hline & & $(0.044)$ & $(0.026)$ & $(0.036)$ & $(0.086)$ \\
\hline & HH size & -0.015 & 0.001 & $-0.017^{*}$ & -0.024 \\
\hline & & $(0.014)$ & $(0.005)$ & $(0.009)$ & $(0.021)$ \\
\hline & Children (0-5 years) & 0.015 & 0.011 & $0.033^{*}$ & 0.058 \\
\hline \multirow{15}{*}{ N } & & $(0.025)$ & $(0.012)$ & $(0.020)$ & $(0.041)$ \\
\hline & Children (6-12 years) & 0.010 & -0.016 & $0.025^{*}$ & 0.022 \\
\hline & & $(0.017)$ & $(0.010)$ & $(0.014)$ & $(0.032)$ \\
\hline & Children (13-17 years) & $\begin{array}{c}0.010 \\
(0.019)\end{array}$ & $\begin{array}{c}0.001 \\
(0.007)\end{array}$ & $\begin{array}{c}0.012 \\
(0.013)\end{array}$ & $\begin{array}{c}0.024 \\
(0.028)\end{array}$ \\
\hline & Expenditure (Q2) & 0.047 & -0.004 & 0.027 & 0.107 \\
\hline & & $(0.045)$ & $(0.027)$ & $(0.035)$ & $(0.090)$ \\
\hline & Expenditure (Q3) & 0.014 & -0.022 & -0.010 & 0.033 \\
\hline & & $(0.053)$ & $(0.030)$ & $(0.045)$ & $(0.106)$ \\
\hline & Expenditure (Q4) & 0.070 & -0.007 & -0.029 & 0.094 \\
\hline & & $(0.049)$ & $(0.028)$ & $(0.041)$ & $(0.093)$ \\
\hline & Asset index & -0.007 & -0.005 & 0.001 & -0.013 \\
\hline & & $(0.010)$ & $(0.005)$ & $(0.007)$ & $(0.017)$ \\
\hline & Observations & 705 & 705 & 686 & 705 \\
\hline & $R^{2}$ & -0.014 & -0.035 & -0.013 & -0.028 \\
\hline & Kleibergen-Paap F stat & 35.166 & 35.166 & 33.526 & 35.166 \\
\hline
\end{tabular}

Note: The table reports coefficients of IV regressions with standard errors clustered at VSLG level in brackets. ${ }^{*} \mathrm{p}<0.10,{ }^{* *} \mathrm{p}<0.05, * * * \mathrm{p}<0.01$ denote statistical significance. The outcome variable in column 1,2 and 3 is one if women are involved in the decision. Column 4 counts the number of financial decisions women are involved in. Financial literacy is an index which is generated by giving one point for each financial literacy question answered correctly. The instrument used is the average group index of financial literacy excluding the individual considered. 
Table B.7: OLS with FL Factor

\begin{tabular}{|c|c|c|c|c|c|c|c|}
\hline & $\begin{array}{c}(1) \\
\text { Income decision } \\
\text { involved } \\
\beta / \mathrm{SE}\end{array}$ & $\begin{array}{c}(2) \\
\text { Income decision } \\
\text { spouse } \\
\beta / \mathrm{SE}\end{array}$ & $\begin{array}{c}(3) \\
\text { Credit decision } \\
\text { involved } \\
\beta / \mathrm{SE}\end{array}$ & $\begin{array}{c}(4) \\
\text { Credit decision } \\
\text { spouse } \\
\beta / \mathrm{SE}\end{array}$ & $\begin{array}{c}(5) \\
\text { Investment decision } \\
\text { involved } \\
\beta / \mathrm{SE}\end{array}$ & $\begin{array}{c}(6) \\
\text { Investment decision } \\
\text { spouse } \\
\beta / \mathrm{SE}\end{array}$ & $\begin{array}{c}(7) \\
\text { Number decisions } \\
\text { involved in } \\
\beta / \mathrm{SE}\end{array}$ \\
\hline Financial literacy factor & 0.013 & -0.006 & $0.009^{* *}$ & $\begin{array}{l}-0.009 \\
(0.006)\end{array}$ & $0.017^{* *}$ & $-0.020^{* *}$ & $0.046^{* * *}$ \\
\hline \multirow[t]{2}{*}{ Age } & $0.012^{*}$ & -0.002 & $0.009^{* *}$ & -0.005 & $0.015^{* * *}$ & $-0.012^{*}$ & $0.033^{* *}$ \\
\hline & $(0.007)$ & $(0.010)$ & $(0.004)$ & $(0.005)$ & $(0.005)$ & $(0.007)$ & $(0.014)$ \\
\hline \multirow[t]{2}{*}{$\mathrm{Age}^{2}$} & -0.000 & -0.000 & $-0.000^{* *}$ & 0.000 & $-0.000^{* *}$ & 0.000 & $-0.000^{*}$ \\
\hline & $(0.000)$ & $(0.000)$ & $(0.000)$ & $(0.000)$ & $(0.000)$ & $(0.000)$ & $(0.000)$ \\
\hline \multirow[t]{2}{*}{ Spell } & 0.031 & -0.050 & 0.001 & -0.013 & 0.010 & -0.018 & 0.041 \\
\hline & $(0.025)$ & $(0.035)$ & $(0.015)$ & $(0.022)$ & $(0.017)$ & $(0.025)$ & $(0.047)$ \\
\hline Married & $\begin{array}{c}-0.024 \\
(0.046)\end{array}$ & & $\begin{array}{c}-0.022 \\
(0.024)\end{array}$ & & $\begin{array}{c}-0.109^{* * *} \\
(0.033)\end{array}$ & & $\begin{array}{c}-0.122 \\
(0.078)\end{array}$ \\
\hline \multirow[t]{2}{*}{ Widowed } & 0.081 & & 0.002 & & $-0.078^{* *}$ & & 0.074 \\
\hline & $(0.050)$ & & $(0.025)$ & & $(0.033)$ & & $(0.085)$ \\
\hline \multirow[t]{2}{*}{ Divorced } & $0.112^{* *}$ & & -0.012 & & $-0.072^{* *}$ & & 0.095 \\
\hline & $-0.022^{* *}$ & 0.013 & $\begin{array}{l}(0.030) \\
-0.005\end{array}$ & -0.001 & $\begin{array}{l}(0.035) \\
-0.016^{* *}\end{array}$ & 0.007 & $-0.041^{* * *}$ \\
\hline HH size & $(0.009)$ & $(0.013)$ & $(0.004)$ & $(0.005)$ & $(0.006)$ & $(0.008)$ & $(0.015)$ \\
\hline \multirow[t]{2}{*}{ Children (0-5 years) } & 0.026 & -0.020 & 0.011 & -0.014 & 0.020 & -0.025 & $0.053^{*}$ \\
\hline & $(0.018)$ & $(0.024)$ & $(0.009)$ & $(0.012)$ & $(0.013)$ & $(0.016)$ & $(0.028)$ \\
\hline \multirow[t]{2}{*}{ Children (6-12 years) } & 0.015 & -0.013 & -0.007 & 0.013 & $0.022^{* *}$ & $-0.021^{*}$ & 0.034 \\
\hline & $(0.012)$ & $(0.016)$ & $(0.008)$ & $(0.010)$ & $(0.010)$ & $(0.013)$ & $(0.023)$ \\
\hline \multirow[t]{2}{*}{ Children (13-17 years) } & 0.012 & -0.010 & 0.003 & -0.002 & 0.009 & -0.000 & 0.026 \\
\hline & $(0.014)$ & $(0.019)$ & $(0.006)$ & $(0.007)$ & $(0.009)$ & $(0.010)$ & $(0.021)$ \\
\hline \multirow[t]{2}{*}{ Expenditure (Q2) } & $0.045^{*}$ & -0.069 & 0.008 & -0.010 & 0.022 & -0.033 & $0.096^{*}$ \\
\hline & $(0.024)$ & $(0.043)$ & $(0.015)$ & $(0.026)$ & $(0.020)$ & $(0.031)$ & $(0.049)$ \\
\hline \multirow[t]{2}{*}{ Expenditure (Q3) } & 0.014 & -0.049 & -0.006 & -0.000 & 0.000 & 0.002 & 0.040 \\
\hline & $(0.031)$ & $(0.046)$ & $(0.019)$ & $(0.027)$ & $(0.023)$ & $(0.034)$ & $(0.059)$ \\
\hline \multirow[t]{2}{*}{ Expenditure (Q4) } & 0.040 & $-0.105^{* *}$ & 0.006 & -0.013 & -0.016 & 0.015 & 0.066 \\
\hline & $(0.031)$ & $(0.043)$ & $(0.019)$ & $(0.026)$ & $(0.026)$ & $(0.034)$ & $(0.057)$ \\
\hline \multirow[t]{2}{*}{ Asset index } & -0.007 & 0.007 & 0.001 & 0.005 & 0.004 & -0.001 & -0.005 \\
\hline & $(0.008)$ & $(0.009)$ & $(0.004)$ & $(0.005)$ & $(0.006)$ & $(0.007)$ & $(0.014)$ \\
\hline Observations & 1057 & 705 & 1057 & 705 & 1033 & 686 & 1057 \\
\hline$R^{2}$ & 0.061 & 0.019 & 0.022 & 0.013 & 0.042 & 0.038 & 0.068 \\
\hline
\end{tabular}

Note: The table reports coefficients of multivariate regressions with standard errors clustered at VSLG level in brackets. $* \mathrm{p}<0.10, * * \mathrm{p}<0.05, * * * \mathrm{p}<0.01$ denote statistical significance. The outcome variable in column 1, 3 and 5 is one if women are involved in the decision. The outcome variable in columns 2,4 and 6 is one if their husbands decide alone. Column 7 counts the number of financial decisions women are involved in. Financial literacy is the factor score that includes four questions of financial literacy. 
Table B.8: OLS with FL Dummy

\begin{tabular}{|c|c|c|c|c|c|c|c|}
\hline & $\begin{array}{c}(1) \\
\text { Income decision } \\
\text { involved } \\
\beta / \mathrm{SE}\end{array}$ & $\begin{array}{c}(2) \\
\text { Income decision } \\
\text { spouse } \\
\beta / \mathrm{SE}\end{array}$ & $\begin{array}{c}(3) \\
\text { Credit decision } \\
\text { involved } \\
\beta / \mathrm{SE}\end{array}$ & $\begin{array}{c}(4) \\
\text { Credit decision } \\
\text { spouse } \\
\beta / \mathrm{SE}\end{array}$ & $\begin{array}{c}(5) \\
\text { Investment decision } \\
\text { involved } \\
\beta / \mathrm{SE}\end{array}$ & $\begin{array}{c}(6) \\
\text { Investment decision } \\
\text { spouse } \\
\beta / \mathrm{SE}\end{array}$ & $\begin{array}{c}(7) \\
\text { Number decisions } \\
\text { involved in } \\
\beta / \mathrm{SE}\end{array}$ \\
\hline Financial literacy dummy & $0.050^{* *}$ & -0.033 & 0.020 & -0.024 & $0.040^{* *}$ & $-0.052^{* * *}$ & $0.111^{* *}$ \\
\hline \multirow[t]{2}{*}{ Age } & $0.012^{*}$ & -0.001 & $0.009^{* *}$ & -0.005 & $0.015^{* * *}$ & $-0.012^{*}$ & $0.033^{* *}$ \\
\hline & $(0.007)$ & $(0.010)$ & $(0.004)$ & $(0.005)$ & $(0.005)$ & $(0.007)$ & $(0.014)$ \\
\hline \multirow[t]{2}{*}{$\mathrm{Age}^{2}$} & -0.000 & -0.000 & $-0.000^{* *}$ & 0.000 & $-0.000^{* *}$ & 0.000 & $-0.000^{*}$ \\
\hline & $(0.000)$ & $(0.000)$ & $(0.000)$ & $(0.000)$ & $(0.000)$ & $(0.000)$ & $(0.000)$ \\
\hline \multirow[t]{2}{*}{ Spell } & 0.035 & -0.050 & 0.005 & -0.016 & 0.017 & -0.025 & 0.060 \\
\hline & $(0.024)$ & $(0.034)$ & $(0.015)$ & $(0.021)$ & $(0.017)$ & $(0.024)$ & $(0.045)$ \\
\hline Married & $\begin{array}{c}-0.022 \\
(0.046)\end{array}$ & & $\begin{array}{c}-0.021 \\
(0.025)\end{array}$ & & $\begin{array}{c}-0.107^{* * *} \\
(0.033)\end{array}$ & & $\begin{array}{c}-0.118 \\
(0.078)\end{array}$ \\
\hline \multirow[t]{2}{*}{ Widowed } & $0.085^{*}$ & & 0.003 & & $-0.075^{* *}$ & & 0.081 \\
\hline & $(0.050)$ & & $(0.025)$ & & $(0.033)$ & & $(0.086)$ \\
\hline \multirow[t]{2}{*}{ Divorced } & $0.115^{* *}$ & & -0.011 & & $-0.070^{* *}$ & & 0.100 \\
\hline & $\begin{array}{c}(0.047) \\
-0.022^{* *}\end{array}$ & 0.013 & $\begin{array}{l}(0.031) \\
-0.005\end{array}$ & -0.002 & $\begin{array}{c}(0.036) \\
-0.015^{* *}\end{array}$ & 0.006 & $\begin{array}{l}(0.093) \\
-0.040^{* * *}\end{array}$ \\
\hline HH size & $(0.009)$ & $(0.013)$ & $(0.004)$ & $(0.005)$ & $(0.006)$ & $(0.008)$ & $(0.015)$ \\
\hline \multirow[t]{2}{*}{ Children (0-5 years) } & 0.025 & -0.020 & 0.011 & -0.015 & 0.020 & -0.026 & $0.053^{*}$ \\
\hline & $(0.018)$ & $(0.024)$ & $(0.009)$ & $(0.012)$ & $(0.013)$ & $(0.016)$ & $(0.028)$ \\
\hline \multirow[t]{2}{*}{ Children (6-12 years) } & 0.015 & -0.012 & -0.007 & 0.014 & $0.021^{* *}$ & -0.020 & 0.034 \\
\hline & $(0.012)$ & $(0.016)$ & $(0.008)$ & $(0.010)$ & $(0.010)$ & $(0.013)$ & $(0.023)$ \\
\hline \multirow[t]{2}{*}{ Children (13-17 years) } & 0.012 & -0.011 & 0.003 & -0.003 & 0.009 & -0.001 & 0.027 \\
\hline & $(0.014)$ & $(0.018)$ & $(0.006)$ & $(0.007)$ & $(0.009)$ & $(0.010)$ & $(0.021)$ \\
\hline \multirow[t]{2}{*}{ Expenditure (Q2) } & $0.046^{*}$ & -0.068 & 0.008 & -0.011 & 0.023 & -0.034 & $0.100^{* *}$ \\
\hline & $(0.025)$ & $(0.043)$ & $(0.015)$ & $(0.026)$ & $(0.020)$ & $(0.032)$ & $(0.050)$ \\
\hline \multirow[t]{2}{*}{ Expenditure (Q3) } & 0.014 & -0.049 & -0.005 & -0.003 & 0.002 & -0.002 & 0.046 \\
\hline & $(0.032)$ & $(0.047)$ & $(0.019)$ & $(0.028)$ & $(0.024)$ & $(0.035)$ & $(0.060)$ \\
\hline \multirow[t]{2}{*}{ Expenditure (Q4) } & 0.040 & $-0.104^{* *}$ & 0.008 & -0.015 & -0.015 & 0.013 & 0.072 \\
\hline & $(0.031)$ & $(0.044)$ & $(0.019)$ & $(0.027)$ & $(0.026)$ & $(0.035)$ & $(0.057)$ \\
\hline \multirow[t]{2}{*}{ Asset index } & -0.007 & 0.007 & 0.001 & 0.005 & 0.004 & -0.001 & -0.005 \\
\hline & $(0.008)$ & $(0.009)$ & $(0.004)$ & $(0.005)$ & $(0.006)$ & $(0.007)$ & $(0.014)$ \\
\hline Observations & 1057 & 705 & 1057 & 705 & 1033 & 686 & 1057 \\
\hline$R^{2}$ & 0.063 & 0.020 & 0.021 & 0.013 & 0.041 & 0.037 & 0.066 \\
\hline
\end{tabular}

Note: The table reports coefficients of multivariate regressions with standard errors clustered at VSLG level in brackets. ${ }^{*} \mathrm{p}<0.10,{ }^{* *} \mathrm{p}<0.05,{ }^{* * *} \mathrm{p}<0.01$ denote statistical significance. The outcome variable in column 1, 3 and 5 is one if women are involved in the decision. The outcome variable in columns 2,4 and 6 is one if their husbands decide alone. Column 7 counts the number of financial decisions women are involved in. Financial literacy is a dummy that is one if all financial literacy questions are correctly answered. 
Table B.9: OLS with FL Index and fixed effects

\begin{tabular}{|c|c|c|c|c|c|c|c|}
\hline & $\begin{array}{c}(1) \\
\text { Income decision } \\
\text { involved } \\
\beta / \mathrm{SE}\end{array}$ & $\begin{array}{c}(2) \\
\text { Income decision } \\
\text { spouse } \\
\beta / \mathrm{SE}\end{array}$ & $\begin{array}{c}(3) \\
\text { Credit decision } \\
\text { involved } \\
\beta / \mathrm{SE}\end{array}$ & $\begin{array}{c}(4) \\
\text { Credit decision } \\
\text { spouse } \\
\beta / \mathrm{SE}\end{array}$ & $\begin{array}{c}(5) \\
\text { Investment decision } \\
\text { involved } \\
\beta / \mathrm{SE}\end{array}$ & $\begin{array}{c}(6) \\
\text { Investment decision } \\
\text { spouse } \\
\beta / \mathrm{SE}\end{array}$ & $\begin{array}{c}(7) \\
\text { Number decisions } \\
\text { involved in } \\
\beta / \mathrm{SE}\end{array}$ \\
\hline Financial literacy index & $\begin{array}{c}0.011 \\
(0.011)\end{array}$ & $\begin{array}{c}-0.015 \\
(0.017)\end{array}$ & $\begin{array}{c}0.012^{*} \\
(0.006)\end{array}$ & $\begin{array}{c}-0.010 \\
(0.009)\end{array}$ & $\begin{array}{c}0.011 \\
(0.008)\end{array}$ & $\begin{array}{c}-0.013 \\
(0.012)\end{array}$ & $\begin{array}{c}0.036^{*} \\
(0.020)\end{array}$ \\
\hline Age & $\begin{array}{c}0.011^{*} \\
(0.006)\end{array}$ & $\begin{array}{c}-0.003 \\
(0.012)\end{array}$ & $\begin{array}{c}0.007^{*} \\
(0.003)\end{array}$ & $\begin{array}{c}-0.004 \\
(0.006)\end{array}$ & $\begin{array}{l}0.014^{* * *} \\
(0.005)\end{array}$ & $\begin{array}{c}-0.008 \\
(0.008)\end{array}$ & $\begin{array}{c}0.029^{* *} \\
(0.011)\end{array}$ \\
\hline $\mathrm{Age}^{2}$ & $\begin{array}{c}-0.000 \\
(0.000)\end{array}$ & $\begin{array}{c}-0.000 \\
(0.000)\end{array}$ & $\begin{array}{c}-0.000^{*} \\
(0.000)\end{array}$ & $\begin{array}{c}0.000 \\
(0.000)\end{array}$ & $\begin{array}{c}-0.000^{* *} \\
(0.000)\end{array}$ & $\begin{array}{c}0.000 \\
(0.000)\end{array}$ & $\begin{array}{c}-0.000^{*} \\
(0.000)\end{array}$ \\
\hline Spell & $\begin{array}{c}0.045 \\
(0.028)\end{array}$ & $\begin{array}{c}-0.036 \\
(0.043)\end{array}$ & $\begin{array}{c}-0.024 \\
(0.015)\end{array}$ & $\begin{array}{c}0.023 \\
(0.022)\end{array}$ & $\begin{array}{c}-0.014 \\
(0.021)\end{array}$ & $\begin{array}{c}0.035 \\
(0.029)\end{array}$ & $\begin{array}{c}0.009 \\
(0.049)\end{array}$ \\
\hline Married & $\begin{array}{c}-0.012 \\
(0.054)\end{array}$ & & $\begin{array}{c}-0.022 \\
(0.029)\end{array}$ & & $\begin{array}{c}-0.129^{* * *} \\
(0.041)\end{array}$ & & $\begin{array}{c}-0.144 \\
(0.097)\end{array}$ \\
\hline Widowed & $\begin{array}{c}0.101 \\
(0.064)\end{array}$ & & $\begin{array}{c}0.004 \\
(0.035)\end{array}$ & & $\begin{array}{r}-0.081^{*} \\
(0.048)\end{array}$ & & $\begin{array}{c}0.075 \\
(0.114)\end{array}$ \\
\hline Divorced & $\begin{array}{c}0.112^{*} \\
(0.067)\end{array}$ & & $\begin{array}{c}-0.021 \\
(0.037)\end{array}$ & & $\begin{array}{c}-0.092^{*} \\
(0.050)\end{array}$ & & $\begin{array}{c}0.081 \\
(0.120)\end{array}$ \\
\hline HH size & $\begin{array}{c}-0.020^{* *} \\
(0.010)\end{array}$ & $\begin{array}{c}0.012 \\
(0.018)\end{array}$ & $\begin{array}{c}-0.004 \\
(0.005)\end{array}$ & $\begin{array}{c}-0.001 \\
(0.010)\end{array}$ & $\begin{array}{c}-0.011 \\
(0.007)\end{array}$ & $\begin{array}{c}0.005 \\
(0.012)\end{array}$ & $\begin{array}{r}-0.033^{*} \\
(0.018)\end{array}$ \\
\hline Children (0-5 years) & $\begin{array}{c}0.014 \\
(0.018)\end{array}$ & $\begin{array}{c}-0.006 \\
(0.029)\end{array}$ & $\begin{array}{c}0.007 \\
(0.010)\end{array}$ & $\begin{array}{c}-0.004 \\
(0.015)\end{array}$ & $\begin{array}{c}0.020 \\
(0.013)\end{array}$ & $\begin{array}{r}-0.030 \\
(0.019)\end{array}$ & $\begin{array}{c}0.044 \\
(0.032)\end{array}$ \\
\hline Children (6-12 years) & $\begin{array}{c}0.012 \\
(0.014)\end{array}$ & $\begin{array}{c}-0.002 \\
(0.023)\end{array}$ & $\begin{array}{c}-0.003 \\
(0.008)\end{array}$ & $\begin{array}{c}0.015 \\
(0.012)\end{array}$ & $\begin{array}{c}0.017 \\
(0.011)\end{array}$ & $\begin{array}{c}-0.016 \\
(0.015)\end{array}$ & $\begin{array}{c}0.026 \\
(0.026)\end{array}$ \\
\hline Children (13-17 years) & $\begin{array}{c}0.004 \\
(0.017)\end{array}$ & $\begin{array}{c}-0.013 \\
(0.027)\end{array}$ & $\begin{array}{c}0.000 \\
(0.009)\end{array}$ & $\begin{array}{c}0.006 \\
(0.014)\end{array}$ & $\begin{array}{c}0.005 \\
(0.013)\end{array}$ & $\begin{array}{c}0.003 \\
(0.018)\end{array}$ & $\begin{array}{c}0.009 \\
(0.030)\end{array}$ \\
\hline Expenditure (Q2) & $\begin{array}{c}0.035 \\
(0.034)\end{array}$ & $\begin{array}{c}-0.073 \\
(0.056)\end{array}$ & $\begin{array}{c}0.030 \\
(0.018)\end{array}$ & $\begin{array}{c}-0.024 \\
(0.029)\end{array}$ & $\begin{array}{c}0.044^{*} \\
(0.025)\end{array}$ & $\begin{array}{c}-0.040 \\
(0.038)\end{array}$ & $\begin{array}{l}0.129 * * \\
(0.060)\end{array}$ \\
\hline Expenditure (Q3) & $\begin{array}{c}0.038 \\
(0.036)\end{array}$ & $\begin{array}{r}-0.100^{*} \\
(0.058)\end{array}$ & $\begin{array}{c}0.013 \\
(0.020)\end{array}$ & $\begin{array}{c}-0.022 \\
(0.031)\end{array}$ & $\begin{array}{c}0.022 \\
(0.027)\end{array}$ & $\begin{array}{c}-0.021 \\
(0.039)\end{array}$ & $\begin{array}{c}0.108^{*} \\
(0.064)\end{array}$ \\
\hline Expenditure (Q4) & $\begin{array}{c}0.017 \\
(0.039)\end{array}$ & $\begin{array}{c}-0.082 \\
(0.059)\end{array}$ & $\begin{array}{c}0.025 \\
(0.021)\end{array}$ & $\begin{array}{c}-0.046 \\
(0.031)\end{array}$ & $\begin{array}{c}0.032 \\
(0.029)\end{array}$ & $\begin{array}{c}-0.015 \\
(0.040)\end{array}$ & $\begin{array}{c}0.122^{*} \\
(0.069)\end{array}$ \\
\hline Asset index & $\begin{array}{c}-0.007 \\
(0.009)\end{array}$ & $\begin{array}{c}0.009 \\
(0.014)\end{array}$ & $\begin{array}{c}-0.003 \\
(0.005)\end{array}$ & $\begin{array}{c}0.005 \\
(0.007)\end{array}$ & $\begin{array}{c}-0.000 \\
(0.007)\end{array}$ & $\begin{array}{c}-0.003 \\
(0.009)\end{array}$ & $\begin{array}{c}-0.009 \\
(0.016)\end{array}$ \\
\hline $\begin{array}{l}\text { Observations } \\
R^{2}\end{array}$ & 1057 & 705 & 1057 & 705 & 1033 & 686 & 1057 \\
\hline
\end{tabular}

Note: The table reports coefficients of multivariate regressions with standard errors in brackets and VSLG fixed effects. ${ }^{*} \mathrm{p}<0.10,{ }^{* *} \mathrm{p}<0.05,{ }^{* * *} \mathrm{p}<0.01$ denote statistical significance. The outcome variable in column 1, 3 and 5 is one if women are involved in the decision. The outcome variable in columns 2,4 and 6 is one if their husbands decide alone. Column 7 counts the number of financial decisions women are involved in. Financial literacy is an index which is generated by giving one point for each financial literacy question answered correctly. 
Table B.10: OLS with FL Index and fixed effects (Household)

\begin{tabular}{|c|c|c|c|c|c|c|c|c|}
\hline & $\begin{array}{c}(1) \\
\text { Food } \\
\text { involved } \\
\beta / \mathrm{SE}\end{array}$ & $\begin{array}{c}(2) \\
\text { Food } \\
\text { spouse } \\
\beta / \mathrm{SE}\end{array}$ & $\begin{array}{c}(3) \\
\text { Own health } \\
\text { involved } \\
\beta / \mathrm{SE}\end{array}$ & $\begin{array}{c}(4) \\
\text { Own health } \\
\text { spouse } \\
\beta / \mathrm{SE}\end{array}$ & $\begin{array}{c}(5) \\
\text { Own clothes } \\
\text { involved } \\
\beta / \mathrm{SE}\end{array}$ & $\begin{array}{c}(6) \\
\text { Own clothes } \\
\text { spouse } \\
\beta / \mathrm{SE}\end{array}$ & $\begin{array}{c}(7) \\
\text { Energy } \\
\text { involved } \\
\beta / \mathrm{SE}\end{array}$ & $\begin{array}{l}(8) \\
\text { Energy } \\
\text { spouse } \\
\beta / \mathrm{SE}\end{array}$ \\
\hline Financial literacy index & $\begin{array}{c}0.013 \\
(0.008)\end{array}$ & $\begin{array}{r}-0.022^{*} \\
(0.012)\end{array}$ & $\begin{array}{c}0.008 \\
(0.008)\end{array}$ & $\begin{array}{c}-0.011 \\
(0.011)\end{array}$ & $\begin{array}{c}0.004 \\
(0.008)\end{array}$ & $\begin{array}{c}-0.016 \\
(0.012)\end{array}$ & $\begin{array}{c}0.014 \\
(0.011)\end{array}$ & $\begin{array}{l}-0.016 \\
(0.015)\end{array}$ \\
\hline \multirow[t]{2}{*}{ Age } & $0.018^{* * *}$ & -0.008 & $0.011^{* *}$ & -0.003 & 0.007 & -0.010 & $0.022^{* * *}$ & -0.013 \\
\hline & $(0.005)$ & $(0.008)$ & $(0.004)$ & $(0.008)$ & $(0.004)$ & $(0.008)$ & $(0.006)$ & $(0.011)$ \\
\hline \multirow{2}{*}{$\mathrm{Age}^{2}$} & $-0.000^{* * *}$ & 0.000 & $-0.000^{* *}$ & 0.000 & -0.000 & 0.000 & $-0.000 * * *$ & 0.000 \\
\hline & $(0.000)$ & $(0.000)$ & $(0.000)$ & $(0.000)$ & $(0.000)$ & $(0.000)$ & $(0.000)$ & $(0.000)$ \\
\hline \multirow[t]{2}{*}{ Spell } & 0.006 & -0.010 & -0.026 & 0.039 & -0.001 & -0.007 & -0.018 & 0.033 \\
\hline & $(0.020)$ & $(0.028)$ & $(0.019)$ & $(0.028)$ & $(0.019)$ & $(0.029)$ & $(0.026)$ & $(0.038)$ \\
\hline \multirow[t]{2}{*}{ Married } & 0.036 & & -0.044 & & $-0.094^{* *}$ & & -0.004 & \\
\hline & $(0.040)$ & & $(0.038)$ & & $(0.038)$ & & $(0.052)$ & \\
\hline \multirow[t]{2}{*}{ Widowed } & $0.086^{*}$ & & 0.010 & & -0.042 & & $0.127^{* *}$ & \\
\hline & $(0.047)$ & & $(0.044)$ & & $(0.045)$ & & $(0.061)$ & \\
\hline \multirow[t]{2}{*}{ Divorced } & 0.075 & & -0.019 & & -0.055 & & 0.085 & \\
\hline & $(0.049)$ & & $(0.047)$ & & $(0.047)$ & & $(0.064)$ & \\
\hline \multirow[t]{2}{*}{ HH size } & $-0.018^{* *}$ & -0.009 & -0.005 & -0.004 & 0.002 & -0.005 & $-0.016^{*}$ & -0.021 \\
\hline & $(0.007)$ & $(0.012)$ & $(0.007)$ & $(0.012)$ & $(0.007)$ & $(0.012)$ & (0.009) & $(0.016)$ \\
\hline \multirow[t]{2}{*}{ Children (0-5 years) } & 0.012 & 0.018 & -0.006 & 0.006 & 0.006 & -0.023 & 0.001 & 0.042 \\
\hline & $(0.013)$ & $(0.019)$ & $(0.012)$ & $(0.019)$ & $(0.012)$ & $(0.020)$ & $(0.017)$ & $(0.026)$ \\
\hline \multirow[t]{2}{*}{ Children (6-12 years) } & 0.009 & 0.013 & 0.003 & 0.010 & 0.006 & 0.005 & 0.017 & 0.009 \\
\hline & $(0.010)$ & $(0.015)$ & $(0.010)$ & $(0.015)$ & $(0.010)$ & $(0.015)$ & $(0.014)$ & $(0.020)$ \\
\hline \multirow[t]{2}{*}{ Children (13-17 years) } & 0.002 & 0.009 & 0.005 & 0.003 & 0.014 & -0.018 & 0.003 & 0.032 \\
\hline & $(0.012)$ & $(0.018)$ & $(0.012)$ & (0.018) & $(0.012)$ & $(0.019)$ & $(0.016)$ & $(0.025)$ \\
\hline \multirow[t]{2}{*}{ Expenditure (Q2) } & $0.044^{*}$ & -0.046 & $0.044^{*}$ & -0.050 & 0.017 & -0.036 & 0.033 & -0.034 \\
\hline & $(0.025)$ & (0.037) & $(0.023)$ & $(0.036)$ & $(0.023)$ & $(0.038)$ & $(0.032)$ & $(0.050)$ \\
\hline \multirow[t]{2}{*}{ Expenditure (Q3) } & 0.038 & $-0.071^{*}$ & 0.038 & $-0.066^{*}$ & -0.001 & -0.017 & 0.013 & -0.003 \\
\hline & $(0.026)$ & (0.039) & $(0.025)$ & $(0.038)$ & $(0.025)$ & $(0.039)$ & $(0.034)$ & $(0.052)$ \\
\hline \multirow[t]{2}{*}{ Expenditure (Q4) } & 0.031 & -0.057 & $0.048^{*}$ & -0.062 & 0.024 & -0.039 & -0.025 & 0.001 \\
\hline & $(0.028)$ & $(0.040)$ & $(0.027)$ & $(0.039)$ & $(0.027)$ & $(0.040)$ & (0.037) & $(0.053)$ \\
\hline \multirow[t]{2}{*}{ Asset index } & -0.001 & 0.010 & 0.004 & -0.002 & $-0.013^{* *}$ & $0.017^{*}$ & -0.002 & 0.005 \\
\hline & $(0.007)$ & $(0.009)$ & $(0.006)$ & $(0.009)$ & $(0.006)$ & $(0.009)$ & $(0.009)$ & $(0.012)$ \\
\hline \multirow{2}{*}{$\begin{array}{l}\text { Observations } \\
R^{2}\end{array}$} & 1056 & 704 & 1057 & 705 & 1057 & 705 & 1055 & 704 \\
\hline & 0.339 & 0.420 & 0.322 & 0.457 & 0.306 & 0.435 & 0.454 & 0.546 \\
\hline
\end{tabular}

Note: The table reports coefficients of multivariate regressions with standard errors in brackets and VSLG fixed effects. ${ }^{*} \mathrm{p}<0.10, * * \mathrm{p}<0.05,{ }^{* * *} \mathrm{p}<0.01$ denote statistical significance. Financial literacy is an index which is generated by giving one point for each financial literacy question answered correctly. 
Table B.11: OLS with FL Index and fixed effects (Children)

\begin{tabular}{|c|c|c|c|c|c|}
\hline & $\begin{array}{c}(1) \\
\text { Children health } \\
\text { involved } \\
\beta / \mathrm{SE}\end{array}$ & $\begin{array}{c}(2) \\
\text { Children health } \\
\text { spouse } \\
\beta / \mathrm{SE}\end{array}$ & $\begin{array}{c}(3) \\
\text { Children clothes } \\
\text { involved } \\
\beta / \mathrm{SE}\end{array}$ & $\begin{array}{c}(4) \\
\text { Children clothes } \\
\text { spouse } \\
\beta / \mathrm{SE}\end{array}$ & $\begin{array}{c}(5) \\
\text { Number decisions } \\
\text { involved in } \\
\beta / \mathrm{SE}\end{array}$ \\
\hline Financial literacy index & $\begin{array}{c}-0.002 \\
(0.008)\end{array}$ & $\begin{array}{c}-0.002 \\
(0.011)\end{array}$ & $\begin{array}{c}-0.002 \\
(0.008)\end{array}$ & $\begin{array}{c}-0.004 \\
(0.011)\end{array}$ & $\begin{array}{c}0.009 \\
(0.036)\end{array}$ \\
\hline \multirow[t]{2}{*}{ Age } & $0.013^{* *}$ & 0.000 & $0.010^{* *}$ & 0.001 & $0.110^{* * *}$ \\
\hline & $(0.005)$ & $(0.009)$ & $(0.005)$ & $(0.008)$ & $(0.021)$ \\
\hline $\mathrm{Age}^{2}$ & $-0.000^{* *}$ & -0.000 & $-0.000^{*}$ & -0.000 & $-0.001^{* * *}$ \\
\hline \multirow{3}{*}{ Spell } & $(0.000)$ & $(0.000)$ & $(0.000)$ & $(0.000)$ & $(0.000)$ \\
\hline & 0.016 & $-0.051^{*}$ & 0.006 & -0.029 & 0.040 \\
\hline & $(0.020)$ & $(0.027)$ & $(0.019)$ & $(0.026)$ & $(0.089)$ \\
\hline \multirow[t]{2}{*}{ Married } & 0.019 & & -0.003 & & 0.125 \\
\hline & $(0.043)$ & & $(0.042)$ & & $(0.174)$ \\
\hline \multirow[t]{2}{*}{ Widowed } & 0.049 & & 0.026 & & $0.377^{*}$ \\
\hline & $(0.050)$ & & $(0.049)$ & & $(0.205)$ \\
\hline \multirow[t]{2}{*}{ Divorced } & 0.042 & & 0.013 & & 0.284 \\
\hline & $(0.052)$ & & $(0.050)$ & & $(0.215)$ \\
\hline \multirow[t]{2}{*}{ HH size } & -0.011 & 0.009 & -0.003 & -0.004 & $-0.104^{* * *}$ \\
\hline & $(0.008)$ & $(0.013)$ & $(0.008)$ & $(0.012)$ & $(0.031)$ \\
\hline \multirow[t]{2}{*}{ Children (0-5 years) } & 0.009 & -0.007 & 0.007 & -0.005 & $0.378^{* * *}$ \\
\hline & $(0.014)$ & $(0.020)$ & $(0.014)$ & $(0.019)$ & $(0.057)$ \\
\hline \multirow[t]{2}{*}{ Children (6-12 years) } & 0.003 & 0.003 & 0.002 & 0.008 & $0.291^{* * *}$ \\
\hline & $(0.011)$ & $(0.016)$ & $(0.011)$ & $(0.015)$ & $(0.046)$ \\
\hline \multirow[t]{2}{*}{ Children (13-17 years) } & -0.005 & -0.002 & 0.000 & -0.005 & $0.287^{* * *}$ \\
\hline & $(0.013)$ & $(0.018)$ & $(0.012)$ & $(0.017)$ & $(0.054)$ \\
\hline \multirow[t]{2}{*}{ Expenditure (Q2) } & 0.032 & -0.045 & -0.012 & 0.029 & $0.184^{*}$ \\
\hline & $(0.025)$ & $(0.037)$ & $(0.025)$ & (0.035) & $(0.108)$ \\
\hline \multirow[t]{2}{*}{ Expenditure (Q3) } & 0.022 & -0.022 & -0.013 & 0.033 & $0.208^{*}$ \\
\hline & $(0.025)$ & $(0.038)$ & $(0.025)$ & $(0.036)$ & $(0.115)$ \\
\hline \multirow[t]{2}{*}{ Expenditure (Q4) } & 0.024 & -0.023 & 0.001 & 0.024 & $0.231^{*}$ \\
\hline & $(0.027)$ & $(0.038)$ & $(0.027)$ & $(0.036)$ & $(0.124)$ \\
\hline \multirow[t]{2}{*}{ Asset index } & 0.003 & -0.006 & -0.000 & -0.002 & -0.003 \\
\hline & $(0.006)$ & $(0.009)$ & $(0.006)$ & $(0.008)$ & $(0.030)$ \\
\hline \multirow{2}{*}{$\begin{array}{l}\text { Observations } \\
R^{2}\end{array}$} & 863 & 634 & 862 & 634 & 1057 \\
\hline & 0.380 & 0.431 & 0.340 & 0.421 & 0.487 \\
\hline
\end{tabular}

Note: The table reports coefficients of multivariate regressions with standard errors in brackets and VSLG fixed effects. $* \mathrm{p}<0.10, * * \mathrm{p}<0.05, * * * \mathrm{p}<0.01$ denote statistical significance. Financial literacy is an index which is generated by giving one point for each financial literacy question answered correctly. 
Table B.12: IV with FL Index and fixed effects

\begin{tabular}{|c|c|c|c|c|c|c|c|}
\hline & $\begin{array}{c}(1) \\
\text { Income decision } \\
\text { involved } \\
\beta / \mathrm{SE}\end{array}$ & $\begin{array}{c}(2) \\
\text { Income decision } \\
\text { spouse } \\
\beta / \mathrm{SE}\end{array}$ & $\begin{array}{c}(3) \\
\text { Credit decision } \\
\text { involved } \\
\beta / \mathrm{SE}\end{array}$ & $\begin{array}{c}(4) \\
\text { Credit decision } \\
\text { spouse } \\
\beta / \mathrm{SE}\end{array}$ & $\begin{array}{c}(5) \\
\text { Investment decision } \\
\text { involved } \\
\beta / \mathrm{SE}\end{array}$ & $\begin{array}{c}(6) \\
\text { Investment decision } \\
\text { spouse } \\
\beta / \mathrm{SE}\end{array}$ & $\begin{array}{c}(7) \\
\text { Number decisions } \\
\text { involved in } \\
\beta / \mathrm{SE}\end{array}$ \\
\hline \multirow[t]{2}{*}{ Financial literacy index } & 0.010 & -0.015 & $0.011^{* *}$ & -0.009 & 0.010 & -0.013 & $0.035^{* *}$ \\
\hline & $\begin{array}{l}(0.010) \\
0.011 * *\end{array}$ & $\begin{array}{c}(0.013) \\
-0.003\end{array}$ & $\begin{array}{l}(0.005) \\
0.007 * *\end{array}$ & $(0.007)$ & $(0.007)$ & $(0.009)$ & $(0.017)$ \\
\hline Age & $\begin{array}{c}0.011^{* *} \\
(0.005)\end{array}$ & $\begin{array}{r}-0.003 \\
(0.009)\end{array}$ & $\begin{array}{l}0.007 \text { R } \\
(0.003)\end{array}$ & $\begin{array}{c}-0.004 \\
(0.005)\end{array}$ & $\begin{array}{l}0.014^{* * * *} \\
(0.004)\end{array}$ & $\begin{array}{c}-0.008 \\
(0.006)\end{array}$ & $\begin{array}{l}0.029^{* * *} \\
(0.010)\end{array}$ \\
\hline $\mathrm{Age}^{2}$ & $\begin{array}{c}-0.000 \\
(0.000)\end{array}$ & $\begin{array}{r}-0.000 \\
(0.000)\end{array}$ & $\begin{array}{c}-0.000^{*} \\
(0.000)\end{array}$ & $\begin{array}{c}0.000 \\
(0.000)\end{array}$ & $\begin{array}{c}-0.000^{* * *} \\
(0.000)\end{array}$ & $\begin{array}{c}0.000 \\
(0.000)\end{array}$ & $\begin{array}{c}-0.000^{* *} \\
(0.000)\end{array}$ \\
\hline \multirow[t]{2}{*}{ Spell } & $0.045^{*}$ & -0.036 & $-0.024^{*}$ & 0.022 & -0.014 & 0.035 & 0.010 \\
\hline & $(0.023)$ & $(0.033)$ & $(0.013)$ & $(0.017)$ & $(0.017)$ & $(0.022)$ & $(0.042)$ \\
\hline \multirow[t]{2}{*}{ Married } & -0.012 & & -0.022 & & $-0.129^{* * *}$ & & $-0.145^{*}$ \\
\hline & $(0.046)$ & & $(0.025)$ & & $(0.034)$ & & $(0.082)$ \\
\hline \multirow[t]{2}{*}{ Widowed } & $0.101^{*}$ & & 0.004 & & $-0.082^{* *}$ & & 0.075 \\
\hline & $(0.054)$ & & $(0.029)$ & & $(0.040)$ & & $(0.097)$ \\
\hline \multirow[t]{2}{*}{ Divorced } & $0.112^{* *}$ & & -0.021 & & $-0.092^{* *}$ & & 0.080 \\
\hline & $(0.057)$ & & $(0.031)$ & & $(0.043)$ & & $(0.102)$ \\
\hline HH size & $-0.020^{* *}$ & 0.012 & -0.004 & -0.001 & $-0.011^{*}$ & 0.005 & $-0.033^{* *}$ \\
\hline \multirow{2}{*}{ Children (0-5 years) } & & & & & $(0.000)$ & (0.007) & $(0.015)$ \\
\hline & $(0.015)$ & $(0.022)$ & $(0.008)$ & $(0.012)$ & $(0.011)$ & $\begin{array}{l}-0.030 \\
(0.015)\end{array}$ & $\begin{array}{l}0.044 \\
(0.027)\end{array}$ \\
\hline \multirow[t]{2}{*}{ Children (6-12 years) } & 0.012 & -0.002 & -0.003 & 0.015 & $0.017^{*}$ & -0.016 & 0.026 \\
\hline & $(0.012)$ & $(0.017)$ & $(0.007)$ & $(0.009)$ & $(0.009)$ & $(0.012)$ & $(0.022)$ \\
\hline \multirow[t]{2}{*}{ Children (13-17 years) } & 0.004 & -0.013 & 0.000 & 0.006 & 0.005 & 0.003 & 0.008 \\
\hline & $(0.014)$ & $(0.021)$ & $(0.008)$ & $(0.011)$ & $(0.011)$ & $(0.014)$ & $(0.026)$ \\
\hline \multirow[t]{2}{*}{ Expenditure (Q2) } & 0.035 & $-0.073^{*}$ & $0.030^{*}$ & -0.024 & $0.044^{* *}$ & -0.040 & $0.129^{* *}$ \\
\hline & $(0.029)$ & $(0.043)$ & $(0.016)$ & $(0.023)$ & $(0.021)$ & $(0.029)$ & $(0.051)$ \\
\hline \multirow[t]{2}{*}{ Expenditure (Q3) } & 0.038 & $-0.100^{* *}$ & 0.013 & -0.022 & 0.022 & -0.021 & $0.108^{* *}$ \\
\hline & $(0.031)$ & $(0.045)$ & $(0.017)$ & $(0.024)$ & $(0.023)$ & $(0.030)$ & $(0.054)$ \\
\hline \multirow[t]{2}{*}{ Expenditure (Q4) } & 0.017 & $-0.082^{*}$ & 0.025 & $-0.047^{*}$ & 0.033 & -0.015 & $0.122^{* *}$ \\
\hline & $(0.033)$ & $(0.046)$ & $(0.018)$ & $(0.024)$ & $(0.025)$ & $(0.031)$ & $(0.059)$ \\
\hline \multirow[t]{2}{*}{ Asset index } & -0.007 & 0.009 & -0.003 & 0.005 & -0.000 & -0.003 & -0.009 \\
\hline & $(0.008)$ & $(0.011)$ & $(0.004)$ & $(0.006)$ & $(0.006)$ & $(0.007)$ & $(0.014)$ \\
\hline Observations & 1057 & 705 & 1057 & 705 & 1033 & 686 & 1057 \\
\hline$R^{2}$ & 0.326 & 0.396 & 0.328 & 0.426 & 0.350 & 0.467 & 0.350 \\
\hline Cragg-Donald Wald F stat & 151047.792 & 152239.308 & 151047.792 & 152239.308 & 151072.849 & 148285.068 & 151047.792 \\
\hline
\end{tabular}

Note: The table reports coefficients of IV regressions with standard errors in brackets and VSLG fixed effects. $* \mathrm{p}<0.10, * * \mathrm{p}<0.05, * * * \mathrm{p}<0.01$ denote statistical significance. The outcome variable in column 1,3 and 5 is one if women are involved in the decision. The outcome variable in columns 2,4 and 6 is one if their husbands decide alone. Column 7 counts the number of financial decisions women are involved in. Financial literacy is an index which is generated by giving one point for each financial literacy question answered correctly. The instrument used is the average group index of financial literacy excluding the individual considered. 
Table B.13: IV with FL Index and fixed effects (Household)

\begin{tabular}{|c|c|c|c|c|c|c|c|c|}
\hline & $\begin{array}{c}(1) \\
\text { Food } \\
\text { involved } \\
\beta / \mathrm{SE}\end{array}$ & $\begin{array}{c}(2) \\
\text { Food } \\
\text { spouse } \\
\beta / \mathrm{SE}\end{array}$ & $\begin{array}{c}(3) \\
\text { Own health } \\
\text { involved } \\
\beta / \mathrm{SE}\end{array}$ & $\begin{array}{c}(4) \\
\text { Own health } \\
\text { spouse } \\
\beta / \mathrm{SE}\end{array}$ & $\begin{array}{c}(5) \\
\text { Own clothes } \\
\text { involved } \\
\beta / \mathrm{SE}\end{array}$ & $\begin{array}{c}(6) \\
\text { Own clothes } \\
\text { spouse } \\
\beta / \mathrm{SE}\end{array}$ & $\begin{array}{c}(7) \\
\text { Energy } \\
\text { involved } \\
\beta / \mathrm{SE}\end{array}$ & $\begin{array}{c}(8) \\
\text { Energy } \\
\text { spouse } \\
\beta / \mathrm{SE}\end{array}$ \\
\hline Financial literacy index & $\begin{array}{c}0.012^{*} \\
(0.007)\end{array}$ & $\begin{array}{c}-0.023^{* *} \\
(0.009)\end{array}$ & $\begin{array}{c}0.008 \\
(0.007)\end{array}$ & $\begin{array}{c}-0.011 \\
(0.009)\end{array}$ & $\begin{array}{c}0.003 \\
(0.007)\end{array}$ & $\begin{array}{r}-0.015^{*} \\
(0.009)\end{array}$ & $\begin{array}{c}0.013 \\
(0.009)\end{array}$ & $\begin{array}{r}-0.015 \\
(0.012)\end{array}$ \\
\hline Age & $0.018^{* * *}$ & -0.008 & $0.011^{* * *}$ & -0.003 & $0.007^{*}$ & $-0.010^{*}$ & $0.022^{* * *}$ & -0.013 \\
\hline & $(0.004)$ & $(0.006)$ & $(0.004)$ & $(0.006)$ & $(0.004)$ & $(0.006)$ & $(0.005)$ & $(0.008)$ \\
\hline $\mathrm{Age}^{2}$ & $-0.000^{* * *}$ & 0.000 & $-0.000^{* * *}$ & 0.000 & -0.000 & 0.000 & $-0.000^{* * *}$ & 0.000 \\
\hline & $(0.000)$ & $(0.000)$ & $(0.000)$ & $(0.000)$ & $(0.000)$ & $(0.000)$ & $(0.000)$ & $(0.000)$ \\
\hline Spell & $\begin{array}{c}0.006 \\
(0.017)\end{array}$ & $\begin{array}{c}-0.009 \\
(0.022)\end{array}$ & $\begin{array}{r}-0.026 \\
(0.016)\end{array}$ & $\begin{aligned} 0.039^{*} \\
(0.021)\end{aligned}$ & $\begin{array}{c}-0.001 \\
(0.016)\end{array}$ & $\begin{array}{r}-0.007 \\
(0.022)\end{array}$ & $\begin{array}{r}-0.017 \\
(0.022)\end{array}$ & $\begin{array}{c}0.033 \\
(0.030)\end{array}$ \\
\hline Married & 0.036 & & -0.044 & & $-0.094^{* * *}$ & & -0.004 & \\
\hline & $(0.033)$ & & $(0.032)$ & & $(0.032)$ & & $(0.044)$ & \\
\hline Widowed & $0.086^{* *}$ & & 0.010 & & -0.042 & & $0.127^{* *}$ & \\
\hline & $(0.040)$ & & $(0.038)$ & & $(0.038)$ & & $(0.052)$ & \\
\hline Divorced & $\begin{array}{c}0.075^{*} \\
(0.042)\end{array}$ & & $\begin{array}{c}-0.019 \\
(0.040)\end{array}$ & & $\begin{array}{c}-0.055 \\
(0.040)\end{array}$ & & $\begin{array}{c}0.085 \\
(0.054)\end{array}$ & \\
\hline HH size & $-0.018^{* * *}$ & -0.009 & -0.005 & -0.004 & 0.002 & -0.005 & $-0.016^{* *}$ & $-0.021^{*}$ \\
\hline & $(0.006)$ & $(0.009)$ & $(0.006)$ & $(0.009)$ & $(0.006)$ & $(0.009)$ & $(0.008)$ & $(0.013)$ \\
\hline Children (0-5 years) & 0.012 & 0.018 & -0.006 & 0.006 & 0.006 & -0.023 & 0.001 & $0.042^{* *}$ \\
\hline & $(0.011)$ & $(0.015)$ & $(0.010)$ & $(0.015)$ & $(0.010)$ & $(0.015)$ & $(0.014)$ & $(0.020)$ \\
\hline Children (6-12 years) & 0.009 & 0.013 & 0.003 & 0.010 & 0.006 & 0.005 & 0.017 & 0.009 \\
\hline & $(0.009)$ & $(0.012)$ & $(0.008)$ & $(0.011)$ & $(0.008)$ & $(0.012)$ & $(0.012)$ & $(0.016)$ \\
\hline Children (13-17 years) & 0.002 & 0.008 & 0.005 & 0.003 & 0.014 & -0.018 & 0.003 & $0.033^{*}$ \\
\hline & $(0.010)$ & $(0.014)$ & $(0.010)$ & $(0.014)$ & $(0.010)$ & $(0.014)$ & $(0.014)$ & $(0.019)$ \\
\hline Expenditure (Q2) & $0.044^{* *}$ & -0.046 & $0.044^{* *}$ & $-0.050^{*}$ & 0.017 & -0.036 & 0.033 & -0.034 \\
\hline & $(0.021)$ & $(0.029)$ & $(0.020)$ & $(0.028)$ & $(0.020)$ & $(0.029)$ & $(0.027)$ & $(0.039)$ \\
\hline Expenditure (Q3) & $0.038^{*}$ & $-0.071^{* *}$ & $0.038^{*}$ & $-0.066^{* *}$ & -0.001 & -0.017 & 0.013 & -0.003 \\
\hline & $(0.022)$ & $(0.030)$ & $(0.021)$ & $(0.029)$ & $(0.021)$ & $(0.031)$ & $(0.029)$ & $(0.040)$ \\
\hline Expenditure (Q4) & 0.032 & $-0.056^{*}$ & $0.048^{* *}$ & $-0.062^{* *}$ & 0.025 & -0.039 & -0.025 & 0.001 \\
\hline & $(0.024)$ & $(0.031)$ & $(0.023)$ & $(0.030)$ & $(0.023)$ & $(0.031)$ & $(0.031)$ & $(0.041)$ \\
\hline Asset index & -0.001 & 0.010 & 0.004 & -0.002 & $-0.013^{* *}$ & $0.017^{* *}$ & -0.002 & 0.005 \\
\hline & $(0.006)$ & $(0.007)$ & $(0.005)$ & $(0.007)$ & $(0.005)$ & $(0.007)$ & $(0.007)$ & $(0.009)$ \\
\hline Observations & 1056 & 704 & 1057 & 705 & 1057 & 705 & 1055 & 704 \\
\hline$R^{2}$ & 0.339 & 0.420 & 0.322 & 0.457 & 0.306 & 0.435 & 0.454 & 0.546 \\
\hline Cragg-Donald Wald F stat & 156853.272 & 151880.717 & 151047.792 & 152239.308 & 151047.792 & 152239.308 & 149089.431 & 151420.164 \\
\hline
\end{tabular}


Table B.14: IV with FL Index and fixed effects (Children)

\begin{tabular}{|c|c|c|c|c|c|c|}
\hline & & $\begin{array}{c}(1) \\
\text { Children health } \\
\text { involved } \\
\beta / \mathrm{SE}\end{array}$ & $\begin{array}{c}(2) \\
\text { Children health } \\
\text { spouse } \\
\beta / \mathrm{SE}\end{array}$ & $\begin{array}{c}(3) \\
\text { Children clothes } \\
\text { involved } \\
\beta / \mathrm{SE}\end{array}$ & $\begin{array}{c}(4) \\
\text { Children clothes } \\
\text { spouse } \\
\beta / \mathrm{SE}\end{array}$ & $\begin{array}{c}(5) \\
\text { Number decisions } \\
\text { involved in } \\
\beta / \mathrm{SE}\end{array}$ \\
\hline & Financial literacy index & $\begin{array}{c}-0.002 \\
(0.006)\end{array}$ & $\begin{array}{c}-0.002 \\
(0.009)\end{array}$ & $\begin{array}{c}-0.002 \\
(0.006)\end{array}$ & $\begin{array}{c}-0.005 \\
(0.008)\end{array}$ & $\begin{array}{c}0.009 \\
(0.031)\end{array}$ \\
\hline & Age & $0.013^{* * *}$ & 0.000 & $0.010^{* *}$ & 0.001 & $0.110^{* * *}$ \\
\hline & & $(0.004)$ & $(0.007)$ & $(0.004)$ & $(0.006)$ & $(0.017)$ \\
\hline & $\mathrm{Age}^{2}$ & $-0.000^{* * *}$ & -0.000 & $-0.000^{* *}$ & -0.000 & $-0.001^{* * *}$ \\
\hline & & $(0.000)$ & $(0.000)$ & $(0.000)$ & $(0.000)$ & $(0.000)$ \\
\hline & Spell & 0.016 & $-0.051^{* *}$ & 0.006 & -0.029 & 0.040 \\
\hline & & $(0.016)$ & $(0.021)$ & $(0.016)$ & $(0.019)$ & $(0.075)$ \\
\hline & Married & 0.019 & & -0.003 & & 0.125 \\
\hline & & $(0.035)$ & & $(0.034)$ & & $(0.147)$ \\
\hline & Widowed & 0.049 & & 0.026 & & $0.377^{* *}$ \\
\hline & & $(0.041)$ & & $(0.040)$ & & $(0.174)$ \\
\hline & Divorced & 0.042 & & 0.013 & & 0.284 \\
\hline & & $(0.042)$ & & $(0.041)$ & & $(0.183)$ \\
\hline \multirow{19}{*}{ gु } & HH size & -0.011 & 0.009 & -0.003 & -0.004 & $-0.104^{* * *}$ \\
\hline & & $(0.007)$ & $(0.010)$ & $(0.007)$ & $(0.009)$ & $(0.027)$ \\
\hline & Children (0-5 years) & 0.009 & -0.007 & 0.007 & -0.005 & $0.378^{* * *}$ \\
\hline & & $(0.011)$ & $(0.015)$ & $(0.011)$ & $(0.014)$ & $(0.048)$ \\
\hline & Children (6-12 years) & 0.003 & 0.003 & 0.002 & 0.008 & $0.291^{* * *}$ \\
\hline & & $(0.009)$ & $(0.012)$ & $(0.009)$ & $(0.011)$ & $(0.039)$ \\
\hline & Children (13-17 years) & -0.005 & -0.002 & 0.000 & -0.005 & $0.287^{* * *}$ \\
\hline & & $(0.010)$ & $(0.014)$ & $(0.010)$ & $(0.013)$ & $(0.046)$ \\
\hline & Expenditure (Q2) & 0.032 & -0.045 & -0.012 & 0.029 & $0.184^{* *}$ \\
\hline & & $(0.020)$ & $(0.028)$ & $(0.020)$ & $(0.027)$ & $(0.091)$ \\
\hline & Expenditure (Q3) & 0.022 & -0.022 & -0.013 & 0.033 & $0.208^{* *}$ \\
\hline & & $(0.021)$ & $(0.028)$ & $(0.020)$ & $(0.027)$ & $(0.098)$ \\
\hline & Expenditure (Q4) & 0.024 & -0.023 & 0.001 & 0.024 & $0.231^{* *}$ \\
\hline & & $(0.022)$ & $(0.029)$ & $(0.022)$ & $(0.027)$ & $(0.105)$ \\
\hline & Asset index & 0.003 & -0.006 & -0.000 & -0.002 & -0.003 \\
\hline & & $(0.005)$ & $(0.007)$ & $(0.005)$ & $(0.006)$ & $(0.025)$ \\
\hline & Observations & 863 & 634 & 862 & 634 & 1057 \\
\hline & $R^{2}$ & 0.380 & 0.431 & 0.340 & 0.421 & 0.487 \\
\hline & Cragg-Donald Wald F stat & 148008.309 & 133819.953 & 147633.826 & 133819.953 & 151047.792 \\
\hline
\end{tabular}


Table B.15: IV with FL Index and distance

\begin{tabular}{|c|c|c|c|c|c|c|c|c|}
\hline & & $\begin{array}{c}(1) \\
\text { Income decision } \\
\text { involved } \\
\beta / \mathrm{SE}\end{array}$ & $\begin{array}{c}(2) \\
\text { Income decision } \\
\text { spouse } \\
\beta / \mathrm{SE}\end{array}$ & $\begin{array}{c}(3) \\
\text { Credit decision } \\
\text { involved } \\
\beta / \mathrm{SE}\end{array}$ & $\begin{array}{c}(4) \\
\text { Credit decision } \\
\text { spouse } \\
\beta / \mathrm{SE}\end{array}$ & $\begin{array}{c}(5) \\
\text { Investment decision } \\
\text { involved } \\
\beta / \mathrm{SE}\end{array}$ & $\begin{array}{c}(6) \\
\text { Investment decision } \\
\text { spouse } \\
\beta / \mathrm{SE}\end{array}$ & $\begin{array}{c}(7) \\
\text { Number decisions } \\
\text { involved in } \\
\beta / \mathrm{SE}\end{array}$ \\
\hline & Financial literacy index & $\begin{array}{c}0.060^{*} \\
(0.033)\end{array}$ & $\begin{array}{c}-0.075 \\
(0.046)\end{array}$ & $\begin{array}{c}0.028 \\
(0.018)\end{array}$ & $\begin{array}{c}-0.057^{* *} \\
(0.026)\end{array}$ & $\begin{array}{l}0.066^{* *} \\
(0.030)\end{array}$ & $-0.109 * *$ & $0.170^{* *}$ \\
\hline & Age & $0.013^{* *}$ & -0.004 & $0.010^{* *}$ & -0.006 & $0.015^{* * *}$ & $-0.014^{*}$ & $0.034^{* *}$ \\
\hline & & $(0.007)$ & $(0.010)$ & $(0.004)$ & $(0.005)$ & $(0.005)$ & $(0.007)$ & $(0.014)$ \\
\hline & $\mathrm{Age}^{2}$ & $\begin{array}{c}-0.000 \\
(0.000)\end{array}$ & $\begin{array}{c}0.000 \\
(0.000)\end{array}$ & $\begin{array}{c}-0.000^{* *} \\
(0.000)\end{array}$ & $\begin{array}{c}0.000 \\
(0.000)\end{array}$ & $\begin{array}{c}-0.000^{* *} \\
(0.000)\end{array}$ & $\begin{array}{c}0.000 \\
(0.000)\end{array}$ & $\begin{array}{c}-0.000^{* *} \\
(0.000)\end{array}$ \\
\hline & Spell & $\begin{array}{c}0.006 \\
(0.030)\end{array}$ & $\begin{array}{c}-0.015 \\
(0.042)\end{array}$ & $\begin{array}{c}-0.010 \\
(0.017)\end{array}$ & $\begin{array}{c}0.014 \\
(0.025)\end{array}$ & $\begin{array}{c}-0.020 \\
(0.025)\end{array}$ & $\begin{array}{c}0.033 \\
(0.036)\end{array}$ & $\begin{array}{c}-0.031 \\
(0.060)\end{array}$ \\
\hline & Married & $\begin{array}{c}-0.018 \\
(0.047)\end{array}$ & & $\begin{array}{c}-0.020 \\
(0.024)\end{array}$ & & $\begin{array}{l}-0.104^{* * *} \\
(0.034)\end{array}$ & & $\begin{array}{c}-0.106 \\
(0.080)\end{array}$ \\
\hline & Widowed & $0.093^{*}$ & & 0.008 & & $-0.064^{*}$ & & 0.108 \\
\hline & & $(0.053)$ & & $(0.025)$ & & $(0.034)$ & & $(0.090)$ \\
\hline & Divorced & $0.126^{* *}$ & & -0.006 & & -0.056 & & 0.133 \\
\hline & & $(0.049)$ & & $(0.030)$ & & $(0.035)$ & & $(0.094)$ \\
\hline & HH size & $-0.023^{* * *}$ & 0.016 & -0.006 & 0.000 & $-0.016^{* * *}$ & 0.009 & $-0.043^{* * *}$ \\
\hline \multirow{17}{*}{ G } & & $(0.009)$ & $(0.014)$ & $(0.004)$ & $(0.005)$ & $(0.006)$ & $(0.008)$ & $(0.015)$ \\
\hline & Children (0-5 years) & 0.029 & -0.023 & 0.010 & -0.011 & 0.018 & -0.020 & $0.053^{*}$ \\
\hline & & $(0.018)$ & $(0.025)$ & $(0.010)$ & $(0.013)$ & $(0.014)$ & $(0.018)$ & $(0.029)$ \\
\hline & Children (6-12 years) & 0.014 & -0.011 & -0.008 & 0.015 & $0.020^{*}$ & -0.018 & 0.029 \\
\hline & & $(0.012)$ & $(0.017)$ & $(0.008)$ & $(0.010)$ & $(0.010)$ & $(0.014)$ & $(0.025)$ \\
\hline & Children (13-17 years) & $\begin{array}{c}0.009 \\
(0.014)\end{array}$ & $\begin{array}{c}-0.007 \\
(0.019)\end{array}$ & $\begin{array}{c}0.002 \\
(0.006)\end{array}$ & $\begin{array}{c}-0.001 \\
(0.008)\end{array}$ & $\begin{array}{c}0.008 \\
(0.009)\end{array}$ & $\begin{array}{l}0.004 \\
(0.011)\end{array}$ & $\begin{array}{c}0.022 \\
(0.021)\end{array}$ \\
\hline & Expenditure (Q2) & 0.033 & -0.042 & 0.005 & 0.004 & 0.012 & -0.004 & 0.071 \\
\hline & & $(0.025)$ & $(0.045)$ & $(0.016)$ & $(0.028)$ & $(0.022)$ & $(0.034)$ & $(0.053)$ \\
\hline & Expenditure (Q3) & -0.009 & -0.010 & -0.014 & 0.024 & -0.020 & 0.048 & -0.013 \\
\hline & & $(0.033)$ & $(0.052)$ & $(0.021)$ & $(0.031)$ & $(0.029)$ & $(0.045)$ & $(0.068)$ \\
\hline & Expenditure (Q4) & 0.025 & -0.072 & 0.001 & 0.011 & -0.033 & 0.061 & 0.026 \\
\hline & & (0.033) & $(0.049)$ & $(0.020)$ & $(0.029)$ & $(0.029)$ & $(0.042)$ & $(0.064)$ \\
\hline & Asset index & $\begin{array}{c}-0.008 \\
(0.008)\end{array}$ & $\begin{array}{c}0.006 \\
(0.010)\end{array}$ & $\begin{array}{c}0.001 \\
(0.004)\end{array}$ & $\begin{array}{c}0.004 \\
(0.005)\end{array}$ & $\begin{array}{c}0.004 \\
(0.006)\end{array}$ & $\begin{array}{c}-0.003 \\
(0.008)\end{array}$ & $\begin{array}{c}-0.005 \\
(0.015)\end{array}$ \\
\hline & Observations & 1030 & 686 & 1030 & 686 & 1006 & 667 & 1030 \\
\hline & & 0.050 & -0.010 & 0.016 & -0.040 & -0.005 & -0.099 & 0.029 \\
\hline & Kleibergen-Paap F stat & 26.933 & 20.459 & 26.933 & 20.459 & 25.475 & 19.757 & 26.933 \\
\hline & $\begin{array}{l}\text { Note: The table report } \\
\text { significance. The outco } \\
\text { decide alone. Column } \\
\text { financial literacy quest } \\
\text { the nearest school. }\end{array}$ & $\begin{array}{l}\text { oefficients of IV } \\
\text { e variable in colu } \\
\text { counts the numb } \\
\text { answered corre }\end{array}$ & The instrumer & $\begin{array}{l}\text { women are in } \\
\text { sed is the avera }\end{array}$ & $\begin{array}{l}\text { ged in. Financic } \\
\text { group index of }\end{array}$ & $\begin{array}{l}\text { teracy is an index } \\
\text { ancial literacy exclu }\end{array}$ & $\begin{array}{l}* * \mathrm{p}<0.05, * * * \mathrm{p}< \\
\text { columns } 2,4 \text { and } 6 \\
\mathrm{ch} \text { is generated by giv } \\
\mathrm{g} \text { the individual cons }\end{array}$ & $\begin{array}{l}01 \text { denote statistica } \\
\text { one if their husband } \\
\mathrm{g} \text { one point for eacl } \\
\text { ered and distance t }\end{array}$ \\
\hline
\end{tabular}


Table B.16: IV with FL Index and distance and fixed effects

\begin{tabular}{|c|c|c|c|c|c|c|c|}
\hline & $\begin{array}{c}(1) \\
\text { Income decision } \\
\text { involved } \\
\beta / \mathrm{SE} \\
\end{array}$ & $\begin{array}{c}(2) \\
\text { Income decision } \\
\text { spouse } \\
\beta / \mathrm{SE} \\
\end{array}$ & $\begin{array}{c}(3) \\
\text { Credit decision } \\
\text { involved } \\
\beta / \mathrm{SE} \\
\end{array}$ & $\begin{array}{c}(4) \\
\text { Credit decision } \\
\text { spouse } \\
\beta / \mathrm{SE}\end{array}$ & $\begin{array}{c}(5) \\
\text { Investment decision } \\
\text { involved } \\
\beta / \mathrm{SE}\end{array}$ & $\begin{array}{c}(6) \\
\text { Investment decision } \\
\text { spouse } \\
\beta / \mathrm{SE}\end{array}$ & $\begin{array}{c}(7) \\
\text { Number decisions } \\
\text { involved in } \\
\beta / \mathrm{SE}\end{array}$ \\
\hline Financial literacy index & $\begin{array}{c}0.013 \\
(0.010)\end{array}$ & $\begin{array}{c}-0.019 \\
(0.014)\end{array}$ & $\begin{array}{l}0.011^{* *} \\
(0.005)\end{array}$ & $\begin{array}{c}-0.009 \\
(0.007)\end{array}$ & $\begin{array}{c}0.010 \\
(0.007)\end{array}$ & $\begin{array}{c}-0.013 \\
(0.009)\end{array}$ & $\begin{array}{l}0.039^{* *} \\
(0.017)\end{array}$ \\
\hline \multirow[t]{2}{*}{ Age } & $0.012^{* *}$ & -0.004 & $0.007^{* *}$ & -0.004 & $0.015^{* * *}$ & -0.009 & $0.031^{* * *}$ \\
\hline & $(0.006)$ & $(0.009)$ & $(0.003)$ & $(0.005)$ & $(0.004)$ & $(0.006)$ & $(0.010)$ \\
\hline $\mathrm{Age}^{2}$ & $\begin{array}{r}-0.000 \\
(0.000)\end{array}$ & $\begin{array}{r}-0.000 \\
(0.000)\end{array}$ & $\begin{array}{c}-0.000^{* *} \\
(0.000)\end{array}$ & $\begin{array}{c}0.000 \\
(0.000)\end{array}$ & $\begin{array}{c}-0.000^{* * *} \\
(0.000)\end{array}$ & $\begin{array}{c}0.000 \\
(0.000)\end{array}$ & $\begin{array}{c}-0.000^{* *} \\
(0.000)\end{array}$ \\
\hline \multirow[t]{2}{*}{ Spell } & $0.043^{*}$ & -0.036 & $-0.025^{*}$ & 0.022 & -0.015 & 0.036 & 0.006 \\
\hline & $(0.024)$ & $(0.033)$ & $(0.013)$ & $(0.018)$ & $(0.018)$ & $(0.023)$ & $(0.043)$ \\
\hline \multirow[t]{2}{*}{ Married } & -0.009 & & -0.023 & & $-0.133^{* * *}$ & & $-0.146^{*}$ \\
\hline & $(0.047)$ & & $(0.026)$ & & $(0.035)$ & & $(0.084)$ \\
\hline \multirow[t]{2}{*}{ Widowed } & $0.106^{*}$ & & 0.004 & & $-0.084^{* *}$ & & 0.079 \\
\hline & $(0.055)$ & & $(0.030)$ & & $(0.041)$ & & $(0.099)$ \\
\hline \multirow[t]{2}{*}{ Divorced } & $0.117^{* *}$ & & -0.023 & & $-0.097^{* *}$ & & 0.080 \\
\hline & $(0.058)$ & & $(0.032)$ & & $(0.044)$ & & $(0.104)$ \\
\hline \multirow[t]{2}{*}{ HH size } & $-0.020^{* *}$ & 0.011 & -0.004 & -0.002 & $-0.011^{*}$ & 0.004 & $-0.033^{* *}$ \\
\hline & $(0.008)$ & $(0.014)$ & $(0.005)$ & $(0.008)$ & $(0.006)$ & $(0.010)$ & $(0.015)$ \\
\hline \multirow[t]{2}{*}{ Children (0-5 years) } & 0.019 & -0.015 & 0.007 & -0.004 & $0.020^{*}$ & $-0.031^{* *}$ & $0.049^{*}$ \\
\hline & $(0.015)$ & $(0.023)$ & $(0.008)$ & $(0.012)$ & $(0.011)$ & $(0.015)$ & $(0.027)$ \\
\hline \multirow[t]{2}{*}{ Children (6-12 years) } & 0.013 & -0.003 & -0.003 & 0.015 & $0.017^{*}$ & -0.016 & 0.026 \\
\hline & $(0.012)$ & $(0.018)$ & $(0.007)$ & $(0.009)$ & $(0.009)$ & $(0.012)$ & $(0.022)$ \\
\hline \multirow[t]{2}{*}{ Children (13-17 years) } & 0.001 & -0.009 & 0.000 & 0.006 & 0.005 & 0.003 & 0.005 \\
\hline & $(0.015)$ & $(0.022)$ & $(0.008)$ & $(0.011)$ & $(0.011)$ & $(0.015)$ & $(0.026)$ \\
\hline \multirow[t]{2}{*}{ Expenditure (Q2) } & 0.031 & -0.062 & $0.031^{*}$ & -0.025 & $0.044^{* *}$ & -0.038 & $0.127^{* *}$ \\
\hline & $(0.029)$ & $(0.044)$ & $(0.016)$ & $(0.024)$ & $(0.022)$ & $(0.030)$ & $(0.052)$ \\
\hline \multirow[t]{2}{*}{ Expenditure (Q3) } & 0.032 & $-0.094^{* *}$ & 0.014 & -0.022 & 0.022 & -0.018 & $0.104^{*}$ \\
\hline & $(0.031)$ & $(0.046)$ & $(0.017)$ & $(0.024)$ & $(0.023)$ & $(0.031)$ & $(0.056)$ \\
\hline Expenditure (Q4) & $\begin{array}{c}0.012 \\
(0.034)\end{array}$ & $\begin{array}{c}-0.073 \\
(0.047)\end{array}$ & $\begin{array}{c}0.026 \\
(0.018)\end{array}$ & $\begin{array}{c}-0.047^{*} \\
(0.025)\end{array}$ & $\begin{array}{c}0.034 \\
(0.025)\end{array}$ & $\begin{array}{c}-0.014 \\
(0.032)\end{array}$ & $\begin{array}{c}0.121^{* *} \\
(0.060)\end{array}$ \\
\hline \multirow{2}{*}{ Asset index } & -0.007 & 0.008 & -0.004 & $\begin{array}{c}(0.025) \\
0.005\end{array}$ & $\begin{array}{l}(0.025) \\
-0.000\end{array}$ & $\begin{array}{l}(0.032) \\
-0.003\end{array}$ & $\begin{array}{l}(0.060) \\
-0.008\end{array}$ \\
\hline & $(0.008)$ & $(0.011)$ & $(0.004)$ & $(0.006)$ & $(0.006)$ & $(0.007)$ & $(0.014)$ \\
\hline \multirow{3}{*}{$\begin{array}{l}\text { Observations } \\
R^{2} \\
\text { Cragg-Donald Wald F stat }\end{array}$} & 1030 & 686 & 1030 & 686 & 1006 & 667 & 1030 \\
\hline & 0.328 & 0.396 & 0.328 & 0.425 & 0.350 & 0.466 & 0.351 \\
\hline & 71915.782 & 72658.784 & 71915.782 & 72658.784 & 71814.327 & 70620.739 & 71915.782 \\
\hline $\begin{array}{l}\text { Note: The table reports } \\
\text { significance. The outcome } \\
\text { decide alone. Column } 7 \mathrm{c} \\
\text { financial literacy question } \\
\text { the nearest school. }\end{array}$ & nswered correctly. & The instrument & $d$ errors in bra & roup index of $f$ & $\begin{array}{l}\text { d effects. } * \mathrm{p}<0.10 \\
\text { The outcome variable } \\
\text { teracy is an index } \mathrm{w} \\
\text { ancial literacy exclud }\end{array}$ & $\begin{array}{l}* \mathrm{p}<0.05, * * * \mathrm{p}< \\
\text { columns } 2,4 \text { and } 6 \mathrm{i} \\
\mathrm{h} \text { is generated by giv } \\
\text { the individual cons. }\end{array}$ & $\begin{array}{l}01 \text { denote statistical } \\
\text { one if their husbands } \\
\text { g one point for each } \\
\text { ered and distance to }\end{array}$ \\
\hline
\end{tabular}


Table B.17: Robustness check - Regression results for financial literacy factor score

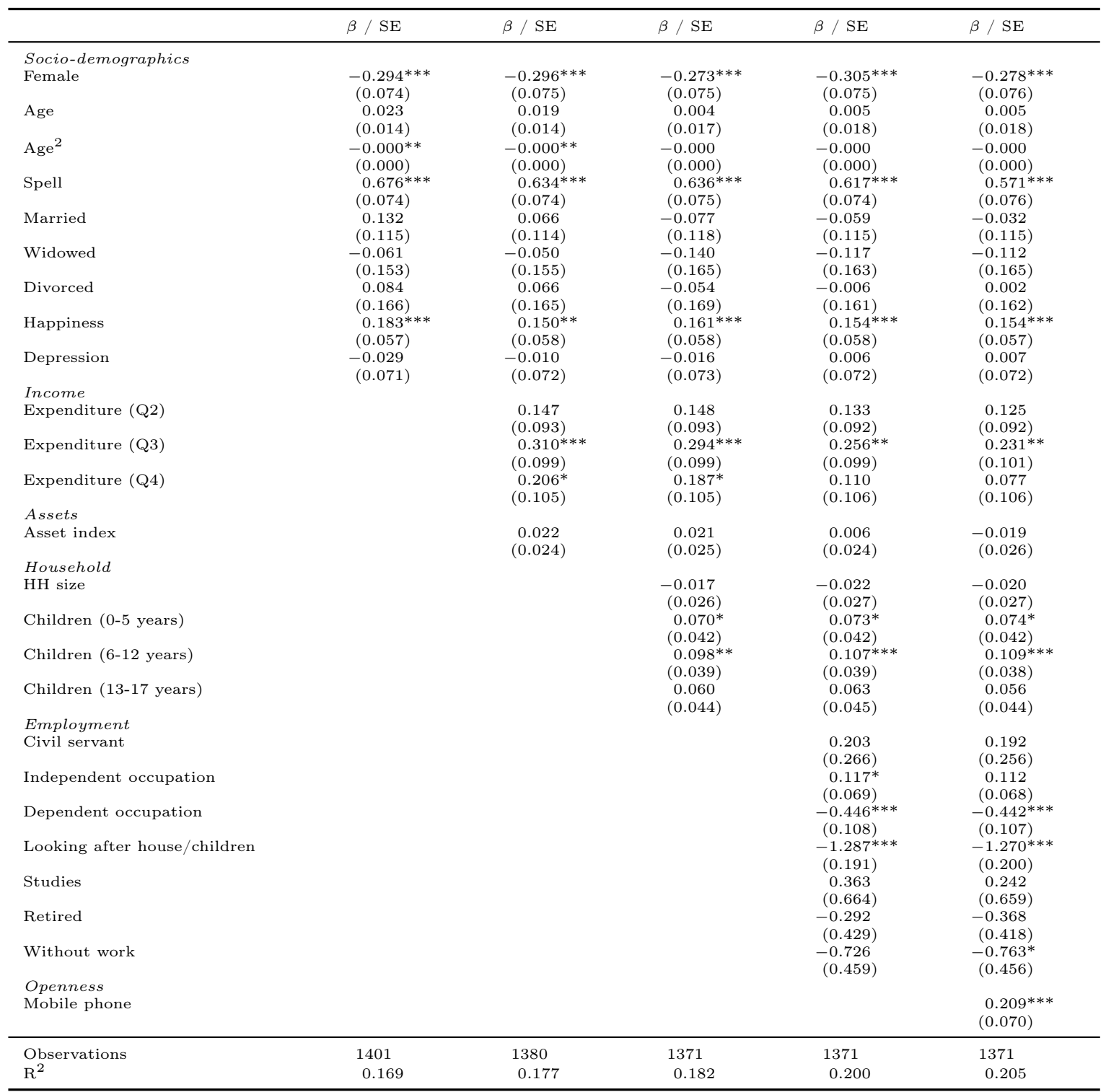

Note: The table reports coefficients of multivariate regression results with standard errors clustered at VSLG level in brackets. The outcome variable is a factor score composed of the four financial literacy questions. Happiness and Depression are scores on a scale designed to measure mental well-being. ${ }^{*} \mathrm{p}<0.10, * * \mathrm{p}<0.05, * * * \mathrm{p}<0.01$ denote statistical significance. 
Table B.18: Robustness check - Regression results for financial literacy dummy

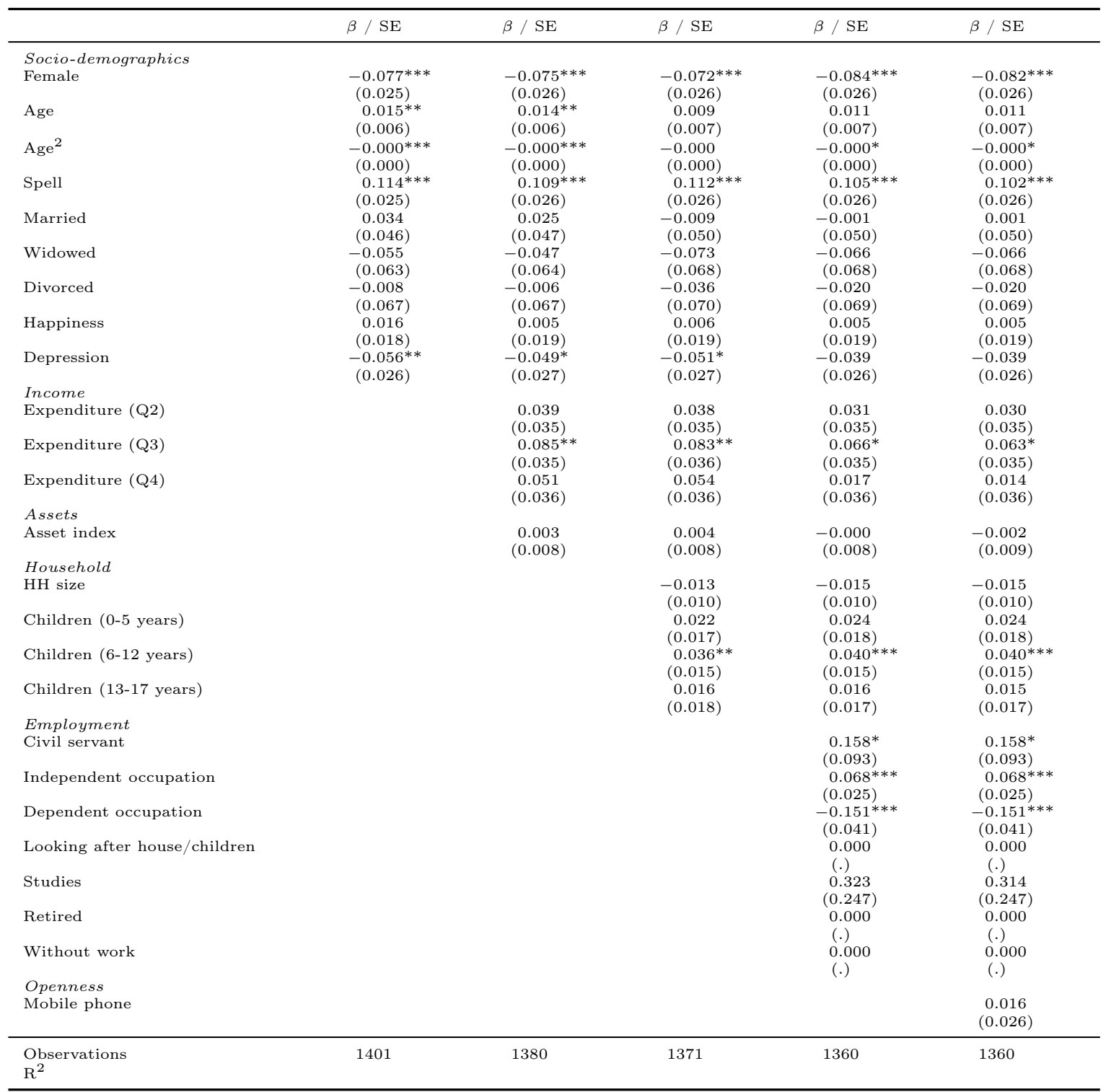

Note: The table reports marginal effects of probit regression results with standard errors clustered at VSLG level in brackets. The outcome variable is a dummy that is one if all financial literacy questions were answered correctly. Happiness and Depression are scores on a scale designed to measure mental well-being. $* \mathrm{p}<0.10, * * \mathrm{p}<0.05, * * *$ $\mathrm{p}<0.01$ denote statistical significance. 
Table B.19: Robustness check - Decomposition results

\begin{tabular}{|c|c|c|c|c|}
\hline & \multicolumn{2}{|c|}{ without Assets } & \multicolumn{2}{|c|}{ with Assets } \\
\hline & Coefficient & Share & Coefficient & Share \\
\hline Financial literacy factor score & \multicolumn{4}{|c|}{ OLS Estimates } \\
\hline Male & $0.365^{* * *}$ & & $0.365^{* * *}$ & \\
\hline Female & $-0.103^{*}$ & & $-0.103^{*}$ & \\
\hline Difference & $0.468^{* * *}$ & 100.000 & $0.468^{* * *}$ & 100.000 \\
\hline Endowment Eff. & $0.222^{* * *}$ & 47.378 & $0.222^{* * *}$ & 47.389 \\
\hline Coefficient Eff. & $0.246^{* *}$ & 52.622 & $0.246^{* * *}$ & 52.611 \\
\hline Financial literacy dummy & \multicolumn{4}{|c|}{ Probit Estimates } \\
\hline Male & $0.340^{* * *}$ & & $0.340^{* * *}$ & \\
\hline Female & $0.217^{* * *}$ & & $0.217^{* * *}$ & \\
\hline Difference & $0.123^{* * *}$ & 100.000 & $0.123^{* * *}$ & 100.000 \\
\hline Endowment Eff. & $0.050^{* * *}$ & 40.915 & $0.050^{* * *}$ & 40.989 \\
\hline Coefficient Eff. & $0.073^{* *}$ & 59.085 & $0.073^{* *}$ & 59.011 \\
\hline
\end{tabular}

Note: ${ }^{*} \mathrm{p}<0.10,{ }^{* *} \mathrm{p}<0.05,{ }^{* * *} \mathrm{p}<0.01$ denote statistical significance. 
Table B.20: Robustness check - Financial literacy and urban characteristics

\begin{tabular}{lcc}
\hline & $\begin{array}{c}\text { Individual level } \\
\beta / \mathrm{SE}\end{array}$ & $\begin{array}{c}\text { Group level } \\
\beta / \mathrm{SE}\end{array}$ \\
\hline Distance to market & 0.159 & 0.132 \\
& $(0.136)$ & $(0.148)$ \\
Distance to sector office & 0.281 & 0.315 \\
& $(0.299)$ & $(0.320)$ \\
Distance to school & 0.031 & 0.078 \\
& $(0.153)$ & $(0.171)$ \\
Distance to health centre & -0.002 & 0.053 \\
& $(0.145)$ & $(0.154)$ \\
Distance to taxi & -0.281 & -0.283 \\
& $(0.179)$ & $(0.195)$ \\
Distance to SACCO & 0.092 & 0.084 \\
Distance to Bank & $(0.354)$ & $(0.379)$ \\
& $-0.804^{* * *}$ & $-0.791^{* * *}$ \\
\hline Observations & $(0.267)$ & $(0.288)$ \\
$\mathrm{R}^{2}$ & 1330 & 224 \\
\hline
\end{tabular}

Note: The table shows beta coefficients of multivariate regression results with standard errors clustered at the sector level in brackets. The outcome variable is the financial literacy index which is generated by giving one point for each financial literacy question answered correctly. The individual level displays the results for the variable used as IV (group cluster average excluding the respondent). The group level displays the results for the group average including all selected group respondents. The distance variables are sector means of binary variables stating 0 if the corresponding object is more than 30 minutes away and 1 if the corresponding object is less than 30 minutes away from the household. This information has been gathered from the second FinScope survey in $2012 .{ }^{*} \mathrm{p}<$ $0.10,{ }^{* *} \mathrm{p}<0.05, * * * \mathrm{p}<0.01$ denote statistical significance. 


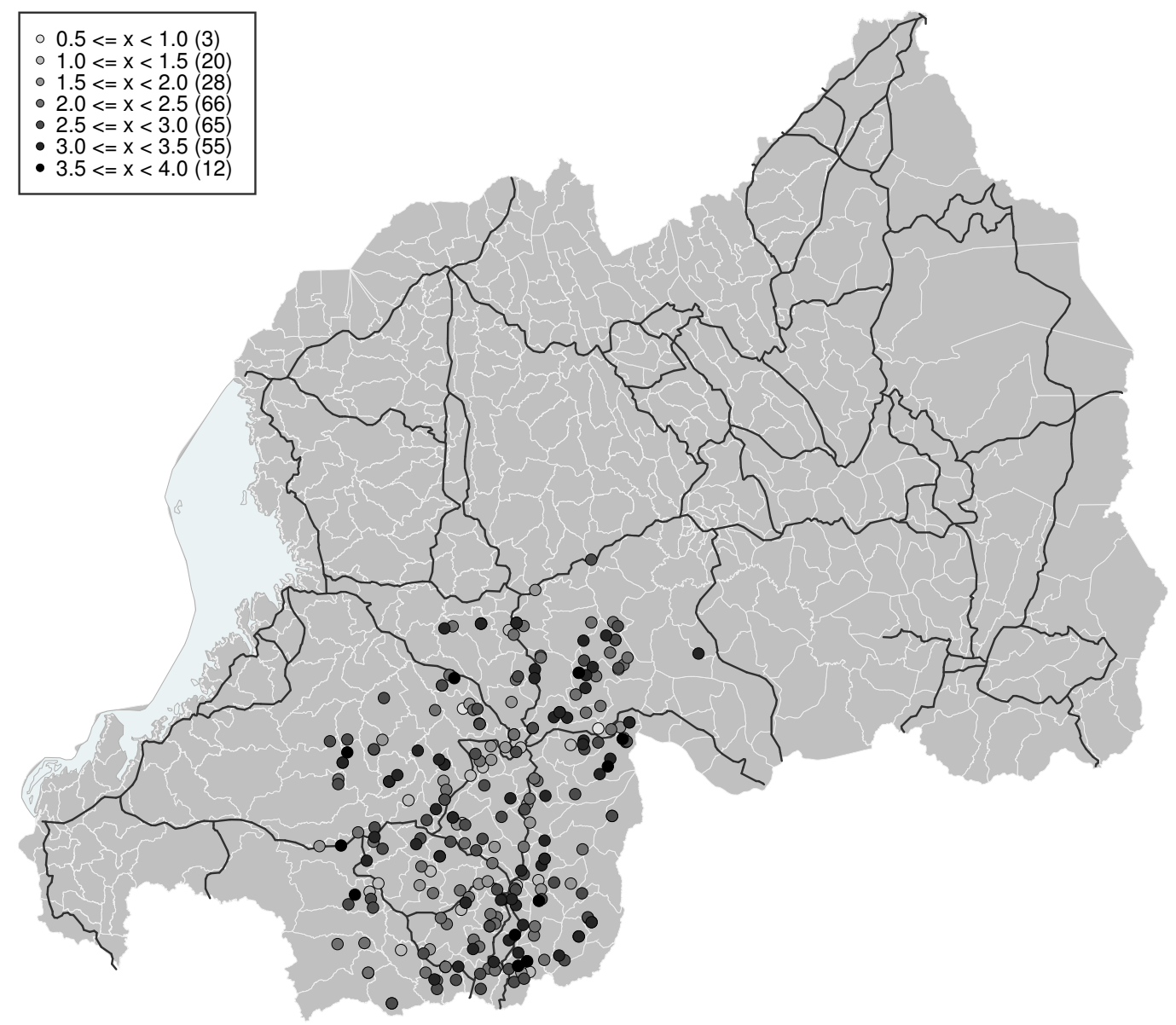

Figure B.1: Geographical distribution of financial literacy group averages 